MARIANA PEREIRA PINHO

\title{
ENRIQUECIMENTO ANTIGÊNICO DE LINHAGENS TUMORAIS: ESTRATÉGIA PARA ABORDAGENS IMUNOTERAPÊUTICAS PERSONALIZADAS
}

Dissertação apresentada ao Programa de PósGraduação em Imunologia do Instituto de Ciências Biomédicas da Universidade de São Paulo para obtenção do Título de Mestre em Ciências.

São Paulo

2014 
MARIANA PEREIRA PINHO

\section{ENRIQUECIMENTO ANTIGÊNICO DE LINHAGENS TUMORAIS: ESTRATÉGIA PARA ABORDAGENS IMUNOTERAPÊUTICAS PERSONALIZADAS}

Dissertação apresentada ao Programa de PósGraduação em Imunologia do Instituto de Ciências Biomédicas da Universidade de São Paulo para obtenção do Título de Mestre em Ciências.

Área de concentração: Imunologia

Orientador: Prof. Dr. José Alexandre M. Barbuto Versão Original

São Paulo 2014 
DADOS DE CATALOGAÇÃO NA PUBLICAÇÃO (CIP)

Serviço de Biblioteca e Informação Biomédica do Instituto de Ciências Biomédicas da Universidade de São Paulo

(c) reprodução parcial

Pinho, Mariana Pereira.

Enriquecimento antigênico de linhagens tumorais: estratégia para abordagens imunoterapêutica personalizadas. / Mariana Pereira Pinho. -- São Paulo, 2014.

Orientador: Prof. Dr. José Alexandre Marzagão Barbuto.

Dissertação (Mestrado) - Universidade de São Paulo. Instituto de Ciências Biomédicas. Departamento de Imunologia. Área de concentração: Imunologia. Linha de pesquisa: Imunologia de tumores.

Versão do título para o inglês: Antigenic enrichment of tumor cell lines: a strategy for personalized immunotherapeutic approaches.

$\begin{array}{llll}\text { 1. Células dendríticas 2. RNA mensageiro } & \text { 3. Vacinas } 4 .\end{array}$ Imunoterapia 5. Câncer I. Barbuto, Prof. Dr. José Alexandre Marzagão II. Universidade de São Paulo. Instituto de Ciências Biomédicas. Programa de Pós-Graduação em Imunologia III. Título. 
Candidato(a):

Título da Dissertação:

Orientador(a):
Mariana Pereira Pinho.

Enriquecimento antigênico de linhagens tumorais: estratégia para abordagens imunoterapêuticas personalizadas.

A Comissão Julgadora dos trabalhos de Defesa da Dissertação de Mestrado, em sessão pública realizada a , considerou
( ) Aprovado(a)
( ) Reprovado(a)

Examinador(a): Assinatura:

Nome:

Instituição:

Examinador(a): Assinatura:

Nome:

Instituição:

Presidente: Assinatura:

Nome:

Instituição: 
São Paulo, 03 de outubro de 2012.

\section{PARECER 1073/CEP}

A Comissão de Ética em Pesquisas em Seres Humanos do ICB, nesta data, AProvou o projeto intitulado: "Enriquecimento antigênico de linhagens tumorais: estratégia para abordagens imunoterapêtiticas personalizadas" dos autores Prof. Dr. JOSE ALEXANDRE MARZAGĀo BARBUTO e aluñ MARIANA PEREIRA PINHO"

Cabe a Pesquisadora executante elaborar e apresentar a este Comitê, relatórios anuais (parciais ou final), de acordo com a resolução 196/06 do Conselho Nacional da Saúde, item IX. 2 letra $c$.

O primeiro relatório deverá ser encaminhado à Secretaria deste CEP em 03.10.2013.

Atenciosamente,

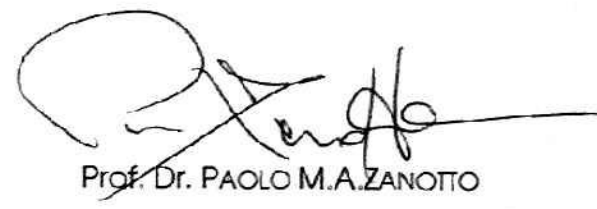

Coordenador da Comissão de Ética em

Pesquisas com Seres Humanos - ICB/USP

Comissão de Ética em Pesquisa com Seres Humanos do Instituto de Ciências Biomédicas / USP Aprovada pela Comissão Nacional de Ética em Pesquisa - CONEP, em 10 de fevereiro de 1998. 
Aos meus pais, irmãos e namorado, que fizeram com que esse sonho virasse realidade. 


\section{AGRADECIMENTOS}

Aos meus pais, Ary e Denize, por todo sacrifício, incentivo e ajuda ao longo da minha vida, e aos meus irmãos por todos os bons momentos que passamos juntos.

Ao meu namorado, Silvio, pelo suporte, paciência e compreensão ao longo desses anos.

Ao meu orientador Prof. Dr. José Alexandre M. Barbuto pela oportunidade de trabalhar em seu laboratório e compartilhar de sua grande capacidade intelectual.

À Prof ${ }^{\mathrm{a}} \operatorname{Dr}^{\mathrm{a}}$. Mary Cleide Sogayar e à sua aluna Ana Cláudia, pelas discussões e pelas grandes contribuições científicas para o trabalho, e também a todo seu laboratório pela excelente disciplina prática ministrada.

À $\operatorname{Prof}^{\mathrm{a}} \mathrm{Dr}^{\mathrm{a}}$. Renata Stripecke por ter me permitido fazer um estágio científico em seu laboratório na Alemanha, e por todas as discussões científicas. Também a todos os membros de seu laboratório, que fizeram com que esta experiência fosse muito proveitosa. Em especial ao seu aluno Bala Sai, por ter me ajudado na execução dos experimentos e ter me passado parte de seus conhecimentos científicos.

A todos os professores do departamento, pelas aulas ministradas e equipamentos cedidos.

À Célia e à Claudinha, por todos os ensinamentos e ajuda no laboratório.

Aos amigos e colegas do laboratório de imunologia de tumores Ana Carolina, Ariane, Bruna, Cecília, Cristiano, Karen, Kleber, Isabella, Maria, Patrícia Toniolo, Patrícia Bergami, Roberta, Roberto, Rodrigo, Sarah pela ajuda e por todos os bons momentos vividos dentro e fora do laboratório. 
Às minhas grandes amigas Bruna e Deborah, por todos os bons momentos vividos e experiências compartilhadas.

Aos enfermeiros do Banco de sangue do Hospital Oswaldo Cruz e a todos os doadores de plaquetas que também foram peça fundamental desse trabalho.

À Beth e Carlos do Centro de Irradiações do IPEN.

À todos os funcionários do departamento, em especial à Eni, João, Amanda e Jotelma pela ajuda nas questões burocráticas.

Aos colegas do departamento pela amizade, discussões e bons momentos vividos.

À FAPESP e ao CNPq pelo apoio financeiro, sem o qual esse trabalho não poderia ser realizado.

E a todas as pessoas que direta ou indiretamente ajudaram na realização deste trabalho.

Obrigada a todos! 
"Descobrir consiste em olhar para o que todo mundo está vendo e pensar uma coisa diferente."

(Roger von Oech) 


\section{RESUMO}

PINHO, M. P. Enriquecimento antigênico de linhagens tumorais: estratégia para abordagens imunoterapêuticas personalizadas. 2014. 128 f. Dissertação (Mestrado em Imunologia) - Instituto de Ciências Biomédicas, Universidade de São Paulo, São Paulo, 2014.

Células dendríticas (DCs) são potentes células apresentadoras de antígenos (APCs) capazes de induzir uma resposta imune antitumoral quando carregadas com antígenos tumorais. Dentre as estratégias de imunoterapia utilizando essas células, se encontra a utilização de híbridos de células dendríticas com células tumorais. O presente projeto avaliou, in vitro, a possibilidade de modificar essa estratégia visando diminuir a quantidade de massa tumoral necessária para o tratamento. Essa modificação consistiria na utilização, como parceiro de fusão das DCs, de células de linhagem tumoral previamente transfectadas com mRNA amplificado de células tumorais contra as quais se pretende induzir resposta. Assim, avaliou-se, primeiramente, a possibilidade da fusão induzir uma resposta antígeno-específica. Para isso, DCs maduras (mDCs) foram diferenciadas a partir de monócitos, obtendo-se células com todas as características de APCs profissionais. As mDCs geradas por esse processo foram fundidas com células da linhagem MDA-MB-231, obtendo-se células duplo-positivas para CD11c e Her2/neu. Esses híbridos expressaram diferentes moléculas de co-estímulo, além de HLA-ABC provenientes dos dois tipos celulares usados para gerar os híbridos, e foram capazes de induzir proliferação de linfócitos $T$ tanto autólogos como alogeneicos. Além disso, os híbridos induziram a diferenciação de linfócitos $\mathrm{T} \mathrm{CD} 4^{+}$com menor expressão de Foxp3, e de linfócitos T CD8 ${ }^{+}$citotóxicos capazes de induzir a morte das células tumorais da linhagem utilizada para formação dos híbridos. Num modelo de células tumorais marcadas pela expressão de um antígeno viral, os híbridos também se mostraram capazes de induzir uma expansão antígeno-específica de linfócitos T CD8. Em seguida, dado que os híbridos foram capazes de induzir uma resposta imune específica, avaliouse a possibilidade de enriquecer uma célula com antígenos de outra, através da transferência de RNA. Células da linhagem MCF-7 que foram transfectadas com RNA total de células da linhagem SK-BR-3 aumentaram a quantidade de mRNA de proteínas presentes nas células SK-BR-3. Além disso, células da linhagem MDA-MB-231, que receberam RNA total de uma célula previamente transfectada com mRNA para GFP, passaram a expressar tal proteína, mostrando que a transferência de RNA é capaz de fazer com que uma célula passe a expressar antígenos presentes em outra. Por fim, analisou-se a possibilidade de se amplificar inespecificamente os mRNAs de uma célula. Foi possível amplificar o mRNA para GFP gerando um material capaz de, quando transfectado, gerar expressão de GFP. Os mRNAs da MDA-MB-231 e da SK-BR-3 amplificados continham mRNAs presentes no preparado inicial, sendo que algumas aumentaram sua representatividade após a amplificação. Esses mRNAs amplificados, porém, não foi capaz de aumentar a expressão das moléculas avaliadas nas células transfectadas, mostrando que o protocolo ainda precisa ser aperfeiçoado. Em conjunto, os resultados apresentados mostram que a nova estratégia de imunoterapia aqui explorada é promissora e merece maior investigação. 
Palavras-chave: Células Dendríticas. RNA mensageiro. Vacinas. Imunoterapia. Câncer. 


\begin{abstract}
PINHO, M. P. Antigenic enrichment of tumor cell lines: a strategy for personalized immunotherapeutic approaches. 2014. 128 p. Master thesis (Immunology) - Instituto de Ciências Biomédicas, Universidade de São Paulo, São Paulo, 2014.

Dendritic cells (DCs) are powerful antigen presenting cells (APCs) that are able to induce antitumor immune responses when loaded with tumor antigens. Among the immunotherapy strategies that utilize these cells, are those that utilize tumor cell dendritic cell hybrids. The present project evaluated, in vitro, the possibility of modifying this strategy, thus diminishing the number of tumor cells needed for the treatment. This modification consists of using cells from tumor cell lines, which were previously transfected with mRNA amplified from tumor cells against which a response is aimed, to fuse with DCs. Thus, first of all, we evaluated if the hybrids could induce an antigen specific immune response. Mature Dendritic cells (mDCs) were differentiated from monocytes, and presented all characteristics of professional APCs. The mDCs were fused with cells from the MDA-MB-231 cell line, generating double-positive cells for CD11c and Her2/neu. These cells expressed different costimulatory molecules and HLA$A B C$ from both cell types used to generate the hybrids, and were also able to induce autologous and allogeneic $\mathrm{T}$ cell proliferation. Moreover, the hybrids induced the differentiation of CD4+ $\mathrm{T}$ lymphocytes with diminished Foxp3 expression, and the differentiation of CD8+ cytotoxic T lymphocytes, that were able to kill tumor cells from the same cell line used for the fusion process. Using a model of tumor cells expressing a viral antigen, we were also able to determine that the hybrids induced the proliferation of antigen-specific CD8+ $T$ cells. Thus, since the hybrids were able to induce a specific immune response, we evaluated if, by the transfer of RNA, tumor cells could be enriched with antigens from another tumor cell line. Cells from the MCF-7 cell line transfected with total RNA from SK-BR-3 cells did increase the amount of mRNAs specific for proteins expressed in SK-BR-3 cells. Furthermore, MDA-MB-231 cells that received total RNA from cell previously transfected with GFP mRNA expressed this protein, showing that cells can express antigens from another one if transfected with their RNA. Lastly, we analyzed if the mRNA from a cell could be nonspecifically amplified. The GFP specific mRNA was successfully amplified, since the amplification product was able to, when transfected, induce GFP expression. The amplified MDA-MB-231 and SK-BR-3 RNAs contained mRNAs that were present in the total extracted RNA, but some were present in increased and other decreased amounts. These amplified mRNAs, however, were not able to increase the expression of the molecules we attempted to detect in the transfected cells, showing that the protocol still need to be improved. Together, these results show that this new strategy is promising and deserves further investigation.
\end{abstract}

Keywords: Dendritic Cells. Messenger RNA. Vaccines. Immunotherapy. Cancer. 


\section{LISTA DE ILUSTRAÇÕES}

Figura 1 - Estratégia de análise dos dados de citometria de fluxo. .........................37

Figura 2 - Estratégia de análise da marcação com pentâmeros.

Figura 3 - Fotografia da eletroforese em gel de agarose do produto de extração de RNA total.

Figura 4 - Especificidade da reação de PCR em tempo real.....................................50

Figura 5 - Esquema do método de amplificação do mRNA. ...................................52

Figura 6 - Esquema do método de transcrição in vitro do cDNA..............................54

Figura 7 - Morfologia das células durante diferenciação de monócitos em DCs. ...57

Figura 8 - Fenótipo celular durante a diferenciação de monócitos em mDCs. .........58

Figura 9 - Fenótipo das linhagens de câncer de mama. ...........................................59

Figura 10 - Marcação dos corantes Green e Violet após dois processos distintos de fusão

Figura 11 - Análise da dupla-positividade na mistura de mDCs e MDA-MB-231......61

Figura 12 - Análise da porcentagem de híbridos utilizando diferentes combinações de corantes e marcadores de membrana...................................................................62

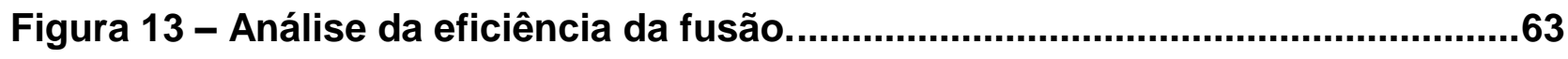

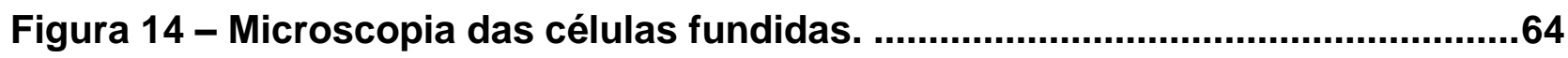

Figura 15 - Porcentagem de híbridos de células tumorais com iDCs ou mDCs......65

Figura 16 - Quantidade de HLA-DR em cada tipo celular após processo de eletroporação. 66

Figura 17 - Fenótipo das células que sofreram o processo da fusão........................67

Figura 18 - Expressão de HLA-ABC nas células fundidas........................................68

Figure 19 - Efeito da irradiação no crescimento de células KA2 ..............................69

Figura 20 - Análise da expressão de CD11c e Her2/neu em células irradiadas. ......70

Figura 21 - Proliferação de linfócitos T induzida pela fusão. ....................................71 
Figura 22 - Produção de citocinas no sobrenadante do ensaio de proliferação de linfócitos T estimulados com a fusão.

Figura 23 - Fotos da sensibilização de linfócitos T com a fusão. .73

Figura 24 - Expressão de CD69 após uma ou duas semanas do início do ensaio de sensibilização. .75

Figura 25 - Citocinas no sobrenadante do ensaio de sensibilização de linfócitos T estimulados com a fusão. 76

Figura 26 - Expressão de fatores de transcrição nos linfócitos T sensibilizados. ..77 Figura 27 - Citotoxicidade induzida por linfócitos T sensibilizados pela fusão........78 Figura 28 - Porcentagem de híbridos de DCs e células KA2 ....................................79

Figura 29 - Número de linfócitos T após sensibilização com híbridos......................80

Figura 30 - Porcentagem de células positivas para cada tetrâmero.........................81

Figura 31 - Poços representativos do ELISPOT..............................................................

Figura 32 - Quantificação do ensaio de ELISPOT..........................................................

Figura 33 - Expressão de GFP após 24 h do tratamento com diferentes agentes de transfecção.

Figura 34 - Expressão relativa de diferentes mRNAs após transfecção com RNA total.

Figura 35 - Expressão de HLA-ABC nas células transfectadas ou não com RNA tumoral total da SK-BR-3.

Figura 36 - Expressão de HLA-ABC em células transfectadas apenas com mRNA que codifica o GFP.

Figura 37 - Expressão de GFP em células transfectadas com RNA de células previamente transfectadas com mRNA para GFP.

Figura 38 - Análise do tamanho dos ácidos nucleicos presentes no produto da amplificação e transcrição do RNA total.

Figura 39 - Expressão de mRNAs específicos antes e após a amplificação do mRNA tumoral.

Figura 40 - Fotos das células tratadas com mRNA amplificado. 
Figura 41 - Expressão de GFP em células MCF-7 e MDA-MB-231 transfectadas com RNA total ou mRNA amplificado.

Figura 42 - Transfecção com diluições seriadas de mRNA amplificado. 93

Figura 43 - Amplificação de diferentes frações da PCR inespecífica seguido de transfecção.

Figura 44 - Amplificação d GFP com protocolo padrão.

Figura 45 - Produto da PCR do RNA total com condições de amplificação

alteradas.

Figura 46 - Produto da PCR do mRNA para GFP com condições da PCR amplificação alteradas.

Figura 47 - Produto da amplificação do mRNA para GFP utilizando condições da PCR alteradas e kit de transcrição.

Figura 48 - Expressão de GFP nas células transfectadas com mRNA para GFP amplificado.

Figura 49 - Produto da amplificação do mRNA da SK-BR-3 utilizando condições da PCR alteradas e kit de transcrição. 100

Figura 50 - Expressão de moléculas antes e após amplificação do RNA tumoral.100 


\section{LISTA DE TABELAS}

Tabela 1 - Anticorpos utilizados para análise por citometria de fluxo......................36

Tabela 2 - Sequências dos primers para PCR e qPCR.................................................48

Tabela 3 - Sequência dos primers que foram usados para produção e amplificação

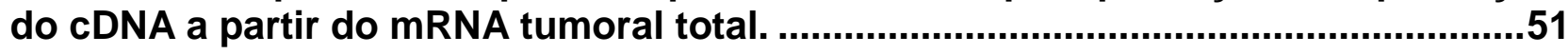

Tabela 4 - Fenótipo dos linfócitos T sensibilizados pela fusão...................................74 


\section{LISTA DE ABREVIATURAS E SIGLAS}

A

ANOVA

APCs

ATP

C

CD

CDNA

CCR7

CEF

CFSE

CNAs

Ct

CTLs

CTP

DCs

DEPC

DMSO

DNA

dNTPs

DTT

EDTA

ER

Foxp3

FSC

G

GM-CSF

GFP

GTP
Adenina

Análise de Variância

Células Apresentadoras de Antígenos

Adenosina trifosfato

Citosina

"Cluster of differentiation"

DNA complementar

Receptor 7 de quimiocinas

Mistura de peptídeos virais

"Carboxyfluorescein Succinimidyl Ester"

Células não aderentes

Threshold Cicle

Linfócitos T citotóxicos

Citosina trifosfato

Células Dendríticas

Material tratado com Dietil Dicarbonato

Dimetilsulfóxido

Ácido Desoxirribonucléico

Desoxirribonucleotídeos Trifosfatados

Ditiotreitol

Ácido Etilenodiaminotetracético

Receptor de estrógeno

Forkhead Box P3

Foward Scatered

Guanina

Fator de Crescimento de Colônias de Granulócitos e Macrófagos

Proteína verde fluorescente

Guanosina trifosfato 


\begin{tabular}{ll} 
HLA-A & Antígeno Leucocitário Humano-A \\
HLA-A2 & Antígeno Leucocitário Humano-A2 \\
HLA-ABC & Antígenos Leucocitários Humanos-A, B e C \\
HLA-DR & Antígeno Leucocitário Humano-DR \\
iDCs & Células Dendríticas Imaturas \\
IFN & Interferon \\
IL & Interleucina \\
K562 & Linhagem de leucemia mieloide crônica \\
KA2 & Linhagem de K562 expressando HLA-A2 \\
KA2/pp65 & Linhagem de KA2 expressando a proteína pp65 \\
MCF-7 & Linhagem celular de adenocarcinoma de mama \\
MDA-MB-231 & Linhagem celular de adenocarcinoma de mama \\
mDCs & Células Dendríticas Maduras \\
MFI & Intensidade Mediana de Fluorescência \\
MHC & Complexo Principal de Histocompatibilidade \\
MIX & Mistura \\
mRNA & RNA mensageiro \\
NTPs & Ribonucleotídeos Trifosfatados \\
PBMCs & Células Mononucleares do Sangue Periférico \\
PBS & Salina Tamponada com Fosfato \\
PCR & Reação em Cadeia da Polimerase \\
pepMIX & Mistura de peptídeos \\
PHA & Fitohemaglutinina A \\
PI & lodeto de propídeo \\
PR & Receptor de progesterona \\
qPCR & PCR quantitativa \\
RFI & Intensidade relativa de fluorescência \\
RT-PCR & Reação da transcriptase reversa \\
SFB & Soro Fetal Bovino \\
SK-BR-3 & Linhagem celular de adenocarcinoma de mama \\
SSC & Side Scatered \\
\hline
\end{tabular}


T

TCR Receptor de Células T

Th

Tregs

TGF- $\beta$

TNF- $\alpha$

UTP

Timina

Linfócitos T helper

Uridina trifosfato
Linfócitos $T$ reguladores

Fator de Crescimento e Transformação $\beta$

Fator de Necrose Tumoral $\alpha$ 


\section{SUMÁRIO}

1 INTRODUÇÃO E JUSTIFICATIVA................................................................22

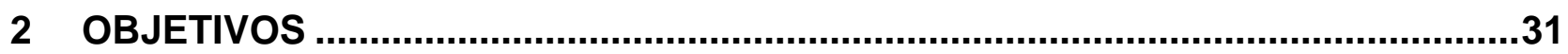

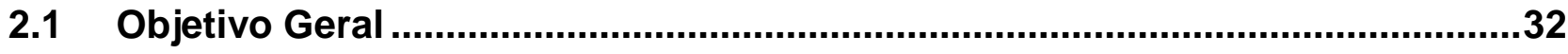

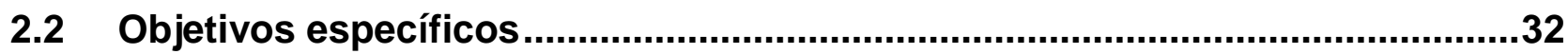

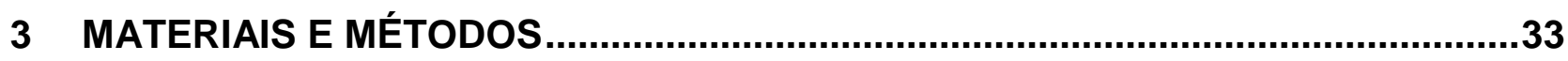

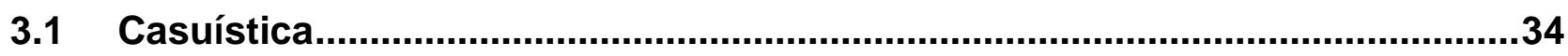

3.2 Diferenciação in vitro de células dendríticas a partir de monócitos do sangue

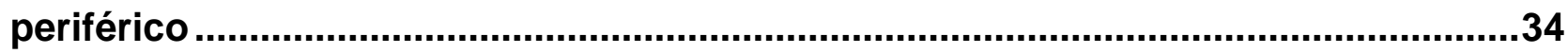

3.3 Marcação com anticorpos para análise por citometria de fluxo .......................35

3.4 Análise do fenótipo de membrana de monócitos, iDCs e mDCs por citometria

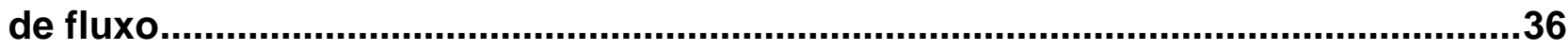

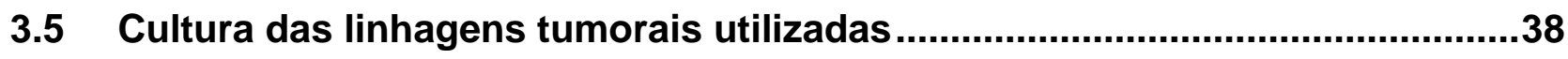

3.6 Fusão de células dendríticas com células tumorais .......................................39

3.7 Análise da porcentagem de híbridos formados pelo processo de fusão.........39

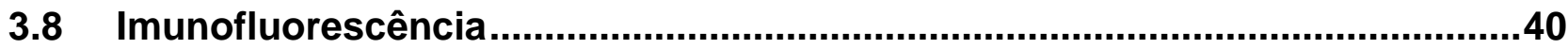

3.9 Análise fenotípica dos híbridos de células dendríticas e células tumorais ....41

3.10 Ensaio de proliferação de linfócitos T...........................................................

3.11 Sensibilização de linfócitos T em macroculturas...........................................41

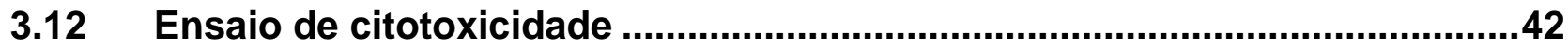

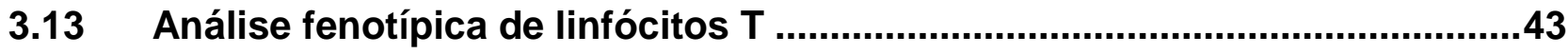

3.14 Marcação intracelular para análise de fatores de transcrição linfocitários .43

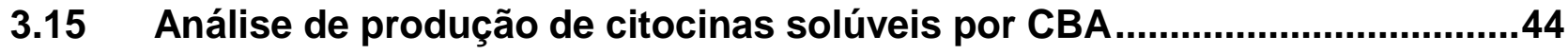

3.16 Sensibilização de linfócitos T CD8 ${ }^{+}$em microculturas ...................................44 
3.17 Análise da especificidade de linfócitos T CD8 utilizando pentâmeros ........44

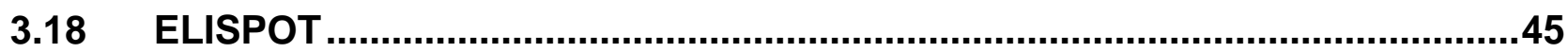

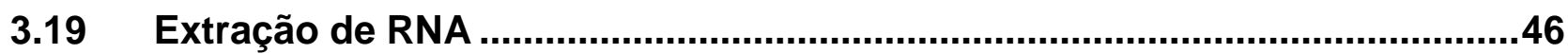

3.20 Transfecção de linhagens tumorais com mRNA tumoral .............................47

3.21 Transcrição reversa (RT-PCR) para detecção de sequências específicas ..48

3.22 Desenho dos primers usados nas reações de PCR e qPCR ….....................48

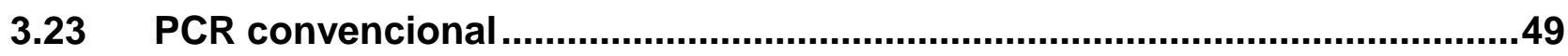

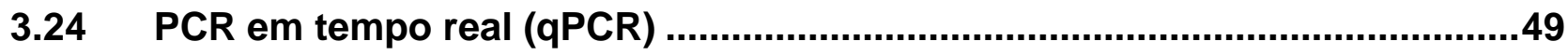

3.25 Transcrição reversa (RT-PCR) e amplificação do RNA total via PCR ...........51

3.26 Transcrição in vitro do cDNA total amplificado.............................................53

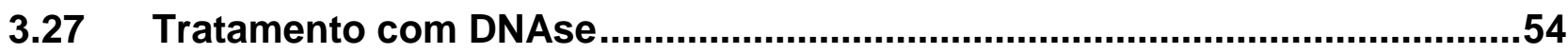

3.28 Recuperação de cDNA presente em gel de agarose ....................................55

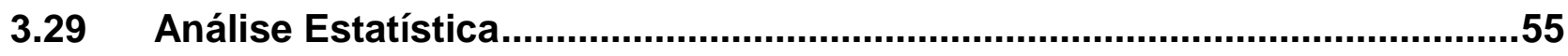

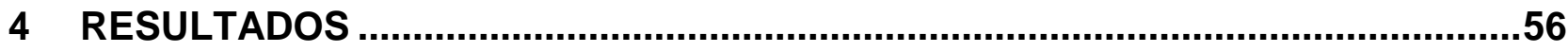

4.1 Fenótipo celular durante a diferenciação de células dendríticas a partir de

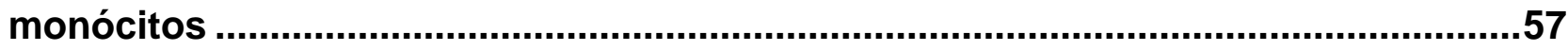

4.2 Fenótipo das linhagens de câncer de mama ..................................................59

4.3 Análise da porcentagem de híbridos após eletroporação ...............................60

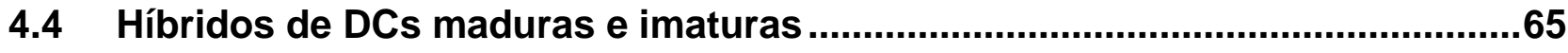

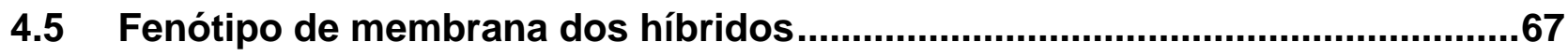

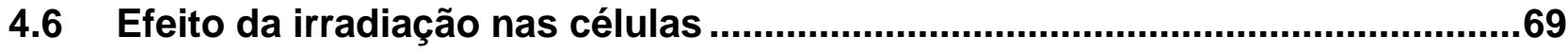

4.7 Capacidade dos híbridos em induzir linfoproliferação .....................................70

4.8 Resposta imune induzida pelos híbridos .............................................................

4.9 Indução de linfócitos T CD8 ${ }^{+}$antígeno-específicos pelos híbridos ..................78 
4.10 Transfecção de linhagens tumorais com RNA total.....................................84

4.11 Amplificação do mRNA tumoral e transfecção do mRNA amplificado .........88

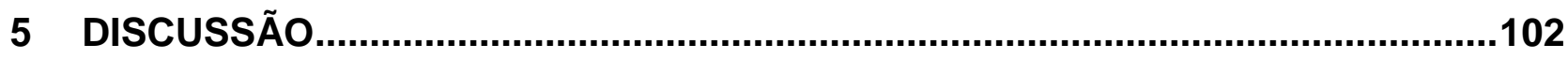

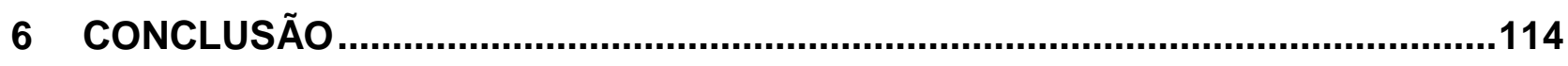

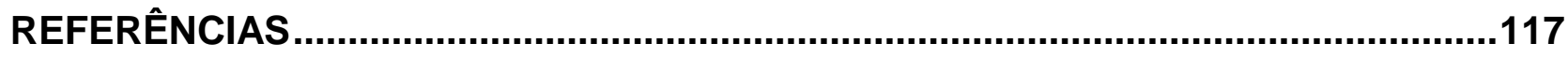




\section{INTRODUÇÃO E JUSTIFICATIVA}


O sistema imune é um sistema de reconhecimento que, através dos seus mecanismos inatos e adaptativos, mantém a homeostase dos tecidos. Por ser capaz de reconhecer e eliminar antígenos associados a patógenos, o sistema imune é amplamente referido como um sistema de defesa do corpo. As células dendríticas (DCs) atuam, nesse contexto, como células apresentadoras de antígenos (APCs; do inglês, antigen presenting cells), sendo, dentre as APCs profissionais, as células mais aptas a induzir uma resposta imune adaptativa (BANCHEREAU, BRIERE, et al., 2000; STEINMAN, BANCHEREAU, 2007).

As DCs constantemente internalizam o conteúdo extracelular do microambiente onde estão. As proteínas que são capturadas por meio desse processo são degradadas em peptídeos que serão acoplados a moléculas de classe II do complexo principal de histocompatibilidade (MHC) e, por meio de apresentação cruzada, a moléculas de classe I do MHC. Essas são as moléculas responsáveis pela apresentação antigênica para os linfócitos $\mathrm{T}$.

Nos tecidos sadios, a maioria das DCs se encontra em um estado denominado imaturo (iDC), monitorando o microambiente através da captura de antígenos (MELLMAN, STEINMAN, 2001). Nesse estado, essas células apresentam alta capacidade endocítica, mas baixa densidade de moléculas coestimuladoras, o que faz com que induzam anergia nos linfócitos T estimulados (STEINMAN, 2003). O contato com produtos de agentes infecciosos ou exposição a estímulos inflamatórios induz mudanças dramáticas nessas células, levando a sua maturação (mDC) (CAUX, MASSACRIER, et al., 1994). As células nesse estado apresentam uma menor capacidade endocítica, mas alta densidade de moléculas coestimuladoras, como CD80 e CD86. As mDCs também expressam o receptor de quimiocinas CCR7, que direciona sua migração para os órgãos linfoides secundários, onde irão atuar na ativação de linfócitos T (SALLUSTO, PALERMO, et al., 1999).

Uma vez nos linfonodos, as mDCs induzem a diferenciação de linfócitos T CD4 $\mathrm{CD8}^{+}$em linfócitos T citotóxicos (CTLs), capazes de eliminar especificamente as células que apresentarem, no contexto das moléculas de classe I do $\mathrm{MHC}$, o antígeno para o qual seu receptor clonal é específico (INABA, YOUNG, STEINMAN, 1987). As células dendríticas também ativam os linfócitos $\mathrm{T}^{\mathrm{CD}} 4^{+} \mathrm{CD}^{-}$, que são responsáveis por 
coordenar a resposta imunológica, sendo comumente denominados de linfócitos $T$ helper (Th) (STEINMAN, 2003). Esses linfócitos $T$ podem se diferenciar em subtipos com diferentes funções efetoras dependendo do estímulo que é dado pelas DCs. A expressão diferencial de fatores de transcrição por cada subtipo de Th permite a caracterização dos mesmos. Quando produzem grandes quantidades de TGF- $\beta$, as DCs induzem, preferencialmente, a diferenciação dos linfócitos $T$ em células reguladoras (Treg), que se caracterizam pela expressão elevada do receptor de alta afinidade para IL-2 (CD25) e o fator de transcrição Foxp3 (MALDONADO, VON ANDRIAN, 2010). Dentre os subtipos de linfócitos $T$ helper efetores, podem-se destacar três subpopulações: linfócitos Th1, que são diferenciados na presença de IL-12 e são caracterizados pela expressão de T-bet e de IFN- $\gamma$; linfócitos Th2, diferenciados na presença de IL-4 e caracterizados pela expressão de GATA-3 e IL-4; e linfócitos Th17, diferenciados, em camundongos, na presença de IL-6 e TGF- $\beta$ e caracterizados pela expressão de ROR $\gamma$ t e IL-17 (KAPSENBERG, 2003).

As células dendríticas apresentam um grande potencial imunoterapêutico devido a sua habilidade de induzir uma resposta adaptativa e a sua capacidade de quebrar a tolerância a antígenos específicos. Sua utilização em protocolos clínicos, porém, só foi possível após a descrição da possibilidade de sua geração in vitro a partir de precursores sanguíneos abundantes (CAUX, DEZUTTER-DAMBUYANT, et al., 1992; SALLUSTO, LANZAVECCHIA, 1994), uma vez que menos do que $1 \%$ das células mononucleares do sangue periférico (PBMCs) de humanos são células dendríticas (HALLER HASSKAMP, ZAPAS, ELIAS, 2005). Desde então, diversas abordagens terapêuticas foram desenvolvidas visando utilizar o potencial imunomodulador dessas células para desencadear uma resposta imune capaz de eliminar especificamente as células tumorais (BANCHEREAU e PALUCKA, 2005; BARBUTO, ENSINA, et al., 2004). Essas estratégias ficaram conhecidas como vacinas antitumorais, uma vez que visam estimular uma resposta efetora do sistema imune.

Para induzir uma resposta imune, as DCs precisam apresentar, no contexto certo, os antígenos contra os quais se quer induzir uma resposta imune. Portanto, para induzir uma resposta anti-tumoral, as DCs precisam ser carregadas com antígenos do tumor, processo que pode ser feito de diferentes formas. Além do lisado tumoral, também 
podem ser usados como fonte de antígenos para carregamento das DCs: células tumorais vivas, debris necróticos, corpos apoptóticos e exossomos derivados de tumores (MOSCA, LYERLY, et al., 2007). O tipo de material utilizado, porém, pode interferir de maneira significativa com o tipo de resposta imune obtida (FRY, SHAND, et al., 2009; HUANG, WANG, et al., 2007).

O carregamento das DCs também pode ser feito sem a utilização de materiais derivados de células tumorais, como, por exemplo, utilizando peptídeos antigênicos sintéticos derivados de antígenos associados ao tumor (TAAs; do inglês, tumor associated antigens). Estudos explorando essa estratégia mostraram que, de fato, é possível observar uma resposta clínica e imunológica dos pacientes vacinados (BROSSART, WIRTHS, et al., 2000). Além disso, essa metodologia não necessita a obtenção de material tumoral do paciente, que costuma ser escasso. Porém, o uso de peptídeos sintéticos apresenta limitações, uma vez que, devido à heterogeneidade das células tumorais, o tumor pode desenvolver resistência à resposta induzida pela vacina, a partir da seleção e expansão de células tumorais que não expressam os antígenos imunizantes (GILBOA, VIEWEG, 2004). Sendo assim, tem-se priorizado cada vez mais metodologias que envolvam a indução de uma resposta imunológica poliantigênica para o tratamento de neoplasias.

Um método que vem sendo explorado envolve a fusão da célula dendrítica com células tumorais, formando células híbridas que seriam capazes de apresentar antígenos tumorais em um contexto imunogênico (CATHELIN, NICOLAS, et al., 2011). A fusão celular para geração dos híbridos pode ocorrer tanto por adição de polietilenoglicol (YANG, SHEN, 2006) quanto por eletroporação (RAMOS, TEISSIÉ, 2000). As células geradas por esses métodos são capazes de induzir uma resposta imune robusta; os resultados clínicos, porém, permanecem ainda insatisfatórios (KOIDO, HOMMA, et al., 2011).

Estas respostas clínicas desanimadoras podem ser um reflexo da utilização de DCs derivadas de monócitos do próprio paciente com câncer para formação dos híbridos (BARBUTO, 2013). Estudos do nosso laboratório mostram que as DCs geradas in vitro, a partir de monócitos do sangue de pacientes com câncer, possuem fenótipo típico de células imaturas (NEVES, ENSINA, et al., 2005). Essas células também apresentam uma 
menor capacidade de induzir linfoproliferação quando comparadas às DCs obtidas de doadores saudáveis, além de induzir uma maior produção de linfócitos $T$ reguladores (RAMOS, CHIN, et al., 2012). As DCs de pacientes com câncer geradas in vitro também são mais suscetíveis às condições encontradas no tumor, como baixo pH (SANTOS, 2010). Portanto, defeitos encontrados já nos precursores sanguíneos de células dendríticas em pacientes com câncer são capazes de explicar a ausência de sucesso pleno da imunoterapia com híbridos autólogos.

Todas essas alterações apontam para a existência de mecanismos de escape tumoral que impedem a destruição das células tumorais pelas células do sistema imune (DUNN, BRUCE, et al., 2002). Sendo as células dendríticas tão importantes no desencadeamento de uma resposta efetora, não é surpreendente que o tumor tenha desenvolvido estratégias para modular sua ação, visando gerar tolerância do sistema (DELLA BELLA, CLERICI, VILLA, 2007). No microambiente tumoral, são produzidos diversos fatores solúveis como VEGF, IL-10 e IL-6 que são capazes de inibir a diferenciação e maturação das DCs (GABRILOVICH, 2004), fatores como o CD83 solúvel que alteram a capacidade de linfoestimulação dessas células (BALEEIRO, BARBUTO, 2008), além de fatores capazes de desencadear o processo de apoptose nas DCs (PINZON-CHARRY, LÓPEZ, 2009). Portanto, ao desenhar protocolos de imunoterapia, deve-se levar em conta o forte equilíbrio existente entre o sistema imune e o tumor nos pacientes acometidos pela doença, que deve ser quebrado para que se consiga uma resposta imune eficaz.

Nesse contexto, surgiram estratégias que utilizam a fusão de células tumorais autólogas com células dendríticas diferenciadas a partir de monócitos de doadores saudáveis (DE GRUIJL, VAN DEN EERTWEGH, et al., 2008; TREFZER, WALDEN, 2003). Além do efeito adjuvante alogeneico, que pode ser capaz de quebrar a tolerância já estabelecida entre o sistema imune e o tumor, essa estratégia permitiria que antígenos tumorais, conhecidos ou não, sejam apresentados mediante a co-estimulação adequada, que não é encontrada em células dendríticas diferenciadas a partir de monócitos do próprio paciente (TREFZER, HERBERTH, et al., 2005). De fato, nosso grupo mostrou que esse protocolo foi capaz de estabilizar a doença em pacientes com melanoma metastático ou com carcinoma celular renal em estágios muito avançados, por um 
período mediano de cerca de 6 meses em $70 \%$ dos casos, sem desencadear efeitos colaterais significativos (BARBUTO, ENSINA, et al., 2004).

Um fator limitante da estratégia de fusão é a quantidade de massa tumoral que deve ser obtida para realizar várias doses da vacinação. Estratégias que necessitem de pouca ou nenhuma massa tumoral têm sido desenvolvidas, tornando possível a vacinação por longo período. Uma estratégia que tem sido explorada é o uso de células tumorais alogênicas, obtidas de linhagens tumorais já estabelecidas, para obtenção de antígenos ou formação de híbridos com células dendríticas (LÓPEZ, PEREDA, et al., 2009; YANG, CAO, et al., 2010). Essa abordagem, porém, sofre de uma falta de especificidade para o repertório de antígenos expressos pelas células tumorais de um dado paciente (SRIVATSAN, PATEL, et al., 2013).

Outra estratégia que vem sendo desenvolvida envolve o uso de células dendríticas geneticamente modificadas para expressar antígenos tumorais por meio da transdução de DNA codificando genes ou da transfecção de mRNAs provenientes das células tumorais de pacientes (MILAZZO, REICHARDT, et al., 2003). Essa estratégia permite a indução de resposta contra os antígenos específicos do próprio paciente (HEISER, MAURICE, et al., 2001). Além disso, utilizando essa abordagem, é possível reduzir a quantidade de massa tumoral necessária, uma vez que o mRNA das células tumorais poderia ser amplificado in vitro a partir de uma pequena quantidade inicial (BAUGH, HILL, et al., 2001; VAN GELDER, VON ZASTROW, et al., 1990).

Para que ocorra a amplificação do mRNA tumoral total, é necessário que o mesmo sofra um processo de transcrição reversa, produzindo fitas de cDNA que podem ser amplificadas através de uma reação de PCR. O cDNA amplificado, então, deve ser submetido a uma reação de transcrição in vitro, formando novas fitas de mRNA que serão utilizadas para a transfecção. Sendo assim, as reações devem ser feitas de forma a inserir a sequência promotora da enzima T7 RNA polimerase, que é usada no processo de transcrição in vitro (BOCZKOWSKI, NAIR, et al., 2000). O material obtido dessa forma mantém cópias de mRNAs das proteínas tumorais expressas pelas células doadoras ( $\mathrm{NI}$, RICHMOND, et al., 2008).

De fato, diversos estudos pré-clínicos feitos em diferentes modelos de diferentes tipos de câncer mostraram que DCs transfectadas com mRNA tumoral, amplificados ou 
não, são capazes de induzir a diferenciação de linfócitos $T$ citotóxicos capazes de eliminar, ao menos in vitro, especificamente as células tumorais (MILANO, RYGIEL, et al., 2007; MÜLLER, TSAKOU, et al., 2004; NI, RICHMOND, et al., 2008). Estudos de fase I, porém, mostram uma resposta clínica muito aquém do esperado, apesar de ser observada uma resposta imune específica para o tumor em muitos dos pacientes (CARUSO, ORME, et al., 2004; SU, DANNULL, et al., 2003). Em um estudo envolvendo o tratamento de pacientes com neuroblastoma, por exemplo, não foi possível observar uma resposta clínica objetiva (CARUSO, ORME, et al., 2005).

É possível observar que as células dendríticas transfectadas com mRNA tumoral expressam, ao menos transientemente, proteínas tumorais (GAO, FAN, et al., 2007; TONIOLO, 2010). Essa expressão transiente é necessária para que as células dendríticas processem tais antígenos e apresentem os peptídeos tumorais em suas moléculas de classe I do MHC. Porém, dentre as proteínas que serão expressas pelas DCs, estão aquelas que as células tumorais produzem visando atrapalhar a resposta imune. Sendo assim, esse fenômeno pode ser uma das explicações para a baixa resposta clínica obtida com esse tipo de metodologia.

As células dendríticas são altamente heterogêneas, e são capazes de modular a expressão de suas proteínas de superfície dependendo do microambiente em que se encontram, sendo conhecidas pela sua grande plasticidade (HUANG, LIU, et al., 2001; ITO, LIU, KADOWAKI, 2005). Estudos do nosso laboratório têm mostrado que a simples exposição aos agentes de transfecção lipídicos é capaz de alterar significativamente a expressão de moléculas de superfície importantes para modulação da resposta imune. Esse comportamento é indesejável para desenvolvimento de um tratamento clínico, uma vez que ainda não se sabe qual perfil de expressão de moléculas é capaz de induzir uma melhor resposta imune. Além disso, as DCs são muito sensíveis a transfecção, podendo apresentar baixa viabilidade dependendo do método utilizado.

Dentro desse contexto, o presente projeto visa desenvolver uma estratégia diferente de carregamento de células dendríticas com antígenos tumorais, que consiste na fusão de células de linhagens tumorais transfectadas com o mRNA amplificado de células tumorais obtidas dos pacientes, com células dendríticas derivadas de doadores saudáveis. A escolha de doadores saudáveis como fonte de precursores para formação 
de células dendríticas decorre do fato das células do paciente apresentarem deficiência funcional, como anteriormente mencionado.

Linhagens tumorais transfectadas com genes capazes de torná-las mais imunogênicas já foram utilizadas, combinadas com a injeção sistêmica de IL-2, em ensaios clínicos (ANTONIA, SEIGNE, et al., 2002). No presente projeto, a transfecção de linhagens com o mRNA tumoral dos pacientes visa introduzir antígenos tumorais dos mesmos, enquanto a fusão dessas células com DCs visa torná-las imunogênicas.

Como modelo para testar essa estratégia, serão utilizadas células de linhagens de câncer de mama. O câncer de mama é o tipo de câncer que mais afeta as mulheres. Estima-se que $12,29 \%$ das mulheres que nasceram hoje serão diagnosticadas com câncer de mama em algum momento durante sua vida (NATIONAL CANCER INSTITUTE, 2012). Felizmente, quando o câncer é diagnosticado em estágios iniciais, a chance de cura é muito grande.

Após a cirurgia para retirada das células tumorais, pacientes com tumores em estágios iniciais com pior prognóstico são submetidos a uma terapia adjuvante. Esse tratamento, que pode ser à base de quimioterapia, radioterapia ou hormonioterapia, visa matar as células tumorais que por ventura ainda estejam no corpo do paciente após o processo cirúrgico (MCARTHUR, HUDIS, 2007). Porém, nem todos os pacientes se beneficiam igualmente dos tratamentos adjuvantes (ENG-WONG, ISAACS, 2010). Além disso, parte das mulheres que passam por esse processo não apresentam mais células tumorais, e, portanto, não enfrentariam recidiva da doença, mas acabam sofrendo com os efeitos colaterais dessas terapias, que, geralmente, são mais do que apenas incômodos (SHAPIRO, RECHT, 2001).

Uma vez que o tumor tenha sido retirado, vacinas utilizando esse material poderiam ser feitas visando desenvolver uma terapia adjuvante com menores efeitos danosos para as pacientes. Nesse contexto, o protocolo em estudo nesse projeto poderia ser interessante para o tratamento dessas pacientes, uma vez que diversas doses de vacinas poderiam ser feitas mesmo com tumores em estágios iniciais, que são muito pequenos.

Tumores de mama podem ser classificados dependendo da expressão, pelas células tumorais, do receptor de estrógeno (ER) ou de progesterona (PR), além da 
superexpressão de Her2/neu, um receptor tirosina quinase da família dos receptores do fator de crescimento epidérmico (EGFR). Tumores que não apresentam nenhuma das três características são denominados triplo-negativos, e apresentam o pior prognóstico quando comparados com os positivos para os receptores ER e PR e os que apresentam superexpressão de Her2/neu (PARISE, BAUER, et al., 2009). Além de alto valor prognóstico, essas proteínas também são utilizadas como alvos por diversas terapias.

Nesse trabalho, células tumorais das linhagens de câncer de mama MDA-MB-231 (triplo-negativa), MCF-7 (ER positiva) e SK-BR-3 (superexpressão de Her2/neu) foram utilizadas como doadoras e receptoras de mRNA, sendo a expressão de ER, PR e Her2/neu avaliadas como marcadores de eficiência do processo de amplificação e transfecção das células. 
2 OBJETIVOS 


\subsection{Objetivo Geral}

Avaliar, in vitro, a possibilidade da utilização de células dendríticas fundidas com células de linhagens tumorais previamente transfectadas com mRNA tumoral, para induzir uma resposta imune específica contra os antígenos de células tumorais provenientes de pacientes.

\subsection{Objetivos específicos}

- Avaliar o fenótipo de células dendríticas diferenciadas a partir de monócitos

- Verificar a formação de híbridos de células dendríticas e células tumorais pelo processo de eletroporação.

- Analisar a capacidade linfoestimulatória dos híbridos, e o tipo de resposta induzida pelos mesmos.

- Avaliar se os híbridos são capazes de gerar uma resposta antígeno-específica.

- Padronizar a técnica de transfecção de linhagens tumorais com RNA.

- Verificar se é possível enriquecer uma célula com antígenos de outra por meio da transferência do RNA total dessa célula.

- Padronizar o protocolo de amplificação de um mRNA de modo a obter maiores quantidades deste, sem perder sua capacidade traducional.

- Avaliar a possibilidade de amplificar uma amostra complexa de mRNA de uma célula, e analisar se há alteração na composição do mRNA antes e após a amplificação.

- Verificar se a transferência do mRNA amplificado de uma célula é capaz de gerar expressão na célula receptora das proteínas presentes na célula doadora. 


\section{MATERIAIS E MÉTODOS}




\subsection{Casuística}

Este trabalho conta com aprovação do Comitê de Ética em Pesquisa do Instituto de Ciências Biomédicas da Universidade de São Paulo (Parecer 1073/CEP) e do Comitê de Ética em Pesquisa do Hospital Alemão Oswaldo Cruz (Parecer 263.720).

Para a diferenciação de células dendríticas, foram utilizadas células mononucleares do sangue periférico, obtidas de câmaras de leuco-redução de doadores de plaquetas do Banco de Sangue do Hospital Alemão Oswaldo Cruz, após consentimento por escrito dos doadores.

\subsection{Diferenciação in vitro de células dendríticas a partir de monócitos do sangue periférico}

O produto de câmara de leuco-redução foi colocado em tubo cônico de $50 \mathrm{~mL}$, diluído 1:1 em solução salina tamponada com fosfato (PBS) e submetido à centrifugação sobre $12 \mathrm{~mL}$ de Ficoll-Paque Plus (GE Healthcare, Uppsala, Suécia) por 30 min a $900 \mathrm{~g}$, na temperatura de $18^{\circ} \mathrm{C}$, para obtenção de células mononucleares. A camada de células mononucleares (PBMCs) foi recuperada em outro tubo, juntamente com RPMI-1640, e centrifugada a $1200 \mathrm{rpm}$ por $10 \mathrm{~min}$. Foram feitas mais duas lavagens a 1100 e $900 \mathrm{rpm}$, respectivamente. $O$ pellet foi coletado sendo determinada a quantidade de células por contagem em câmara de Neubauer.

A separação dos monócitos e posterior diferenciação em células dendríticas foram feitas de duas maneiras diferentes, sendo a segunda apenas utilizada para o ensaio de sensibilização de linfócitos T em microcultura.

No protocolo usual de diferenciação, as PBMCs foram colocadas em garrafas de $75 \mathrm{~cm}^{2}$, na concentração de $1 \times 10^{7}$ células $/ \mathrm{mL}$ e mantidas em estufa com $5 \%$ de $\mathrm{CO}_{2}$ overnight a $37^{\circ} \mathrm{C}$, para aderência. Após este período, as células não aderentes (CNAs) foram coletadas e congeladas em freezer a $-80^{\circ} \mathrm{C}$, em meio contendo soro fetal bovino com $10 \%$ de DMSO, para posterior utilização na co-cultura. As células aderentes foram cultivadas por 7 dias em meio de cultura AIM-V, contendo $50 \mathrm{ng} / \mathrm{mL}$ de GM-CSF (R\&D Systems, Minneapolis, MN, EUA) e $50 \mathrm{ng} / \mathrm{mL}$ de IL-4 (R\&D Systems), em estufa com $5 \%$ 
de $\mathrm{CO}_{2}$ a $37{ }^{\circ} \mathrm{C}$. No quinto dia de cultura, foi acrescentado o fator de necrose tumoral TNF- $\alpha$, para induzir a maturação destas células.

Para estimulação em microculturas, as células dendríticas foram geradas a partir de monócitos purificados com beads magnéticas para CD14 (Miltenyi Biotec, Bergisch Gladbach, Alemanha), de acordo com protocolo fornecido pelo fabricante. Os monócitos foram cultivados por 7 dias em meio de cultura X-VIVO (Lonza, Walkersville, MD, USA), suplementado com GM-CSF (50 ng/ml; Cellgenix, Freiburg, Alemanha) e IFN- $\alpha$ (1000 $\mathrm{U} / \mathrm{ml}$; PBL IFNSource, Piscataway, NJ, EUA). As citocinas foram repostas a cada 3 dias.

\subsection{Marcação com anticorpos para análise por citometria de fluxo}

Anticorpos monoclonais específicos para as moléculas de interesse conjugados a fluorocromos foram utilizados para análise do fenótipo das células utilizadas nesse trabalho (Tabela 1).

Após a contagem em câmara de Neubauer, alíquotas de $1 \times 10^{5}$ células obtidas das culturas foram colocadas em tubos plásticos de $1,5 \mathrm{~mL}$ e lavadas por 20 segundos a $13000 \mathrm{rpm} \mathrm{e} 4{ }^{\circ} \mathrm{C}$, com $200 \mu \mathrm{L} /$ tubo de tampão para citometria (PBS suplementado com $0,5 \%$ de soroalbumina bovina e $0,02 \%$ de azida sódica). Em seguida, as células foram ressuspendidas em $25 \mu \mathrm{L}$ e os anticorpos específicos foram adicionados na concentração apropriada para o marcador de interesse. Esses tubos foram, então, incubados por 20 minutos a $4{ }^{\circ} \mathrm{C}$ e ao abrigo de luz. Após este período, o material foi novamente lavado por duas vezes (20 s, $13000 \mathrm{rpm}, 4{ }^{\circ} \mathrm{C}$ ) com $200 \mu \mathrm{L} /$ tubo de tampão para citometria. Após estas lavagens, as células, já marcadas, foram ressuspendidas em $200 \mu \mathrm{L}$ de tampão para citometria e analisadas no citômetro de fluxo (FACSCalibur ou FACSCanto). Os dados foram adquiridos com a utilização do software CellQuest (BD Biosciences, San Jose, CA, EUA) ou FACS Diva (BD Biosciences) e analisados com o software FlowJo (Tree Stars Inc.). 
Tabela 1 - Anticorpos utilizados para análise por citometria de fluxo. Lista dos anticorpos com suas respectivas especificidades e fluorocromos conjugados.

\begin{tabular}{ll}
\hline Moléculas alvo & Fluorocromo \\
\hline CD11c & PE-Cy7; FITC; PE \\
CD1a & PE \\
CD14 & FITC \\
CD80 & APC-H7; PE \\
CD83 & PE-Cy5.5 \\
CD86 & APC \\
CD274 (PD-L1) & PE \\
CD123 & PE \\
HLA-DR & FITC; APC; V500 \\
HLA-ABC & FITC; PE; APC \\
CCR7 & PE-Cy7 \\
Her2/neu & PE; APC \\
CD3 & FITC; APC \\
CD4 & PE; APC-H7 \\
CD8 & PerCP; V500 \\
CD25 & APC, PE \\
CD45RA & V450 \\
CD45RO & PE \\
PD-1 & PE-Cy7 \\
CD62L & APC \\
CD69 & PE \\
CD38 & V450 \\
\hline \hline
\end{tabular}

3.4 Análise do fenótipo de membrana de monócitos, iDCs e mDCs por citometria de fluxo

Células do dia 0 (monócitos), 5 (iDC) e 7 ( $\mathrm{mDC}$ ) de cultura foram retiradas para determinação do fenótipo de membrana. 

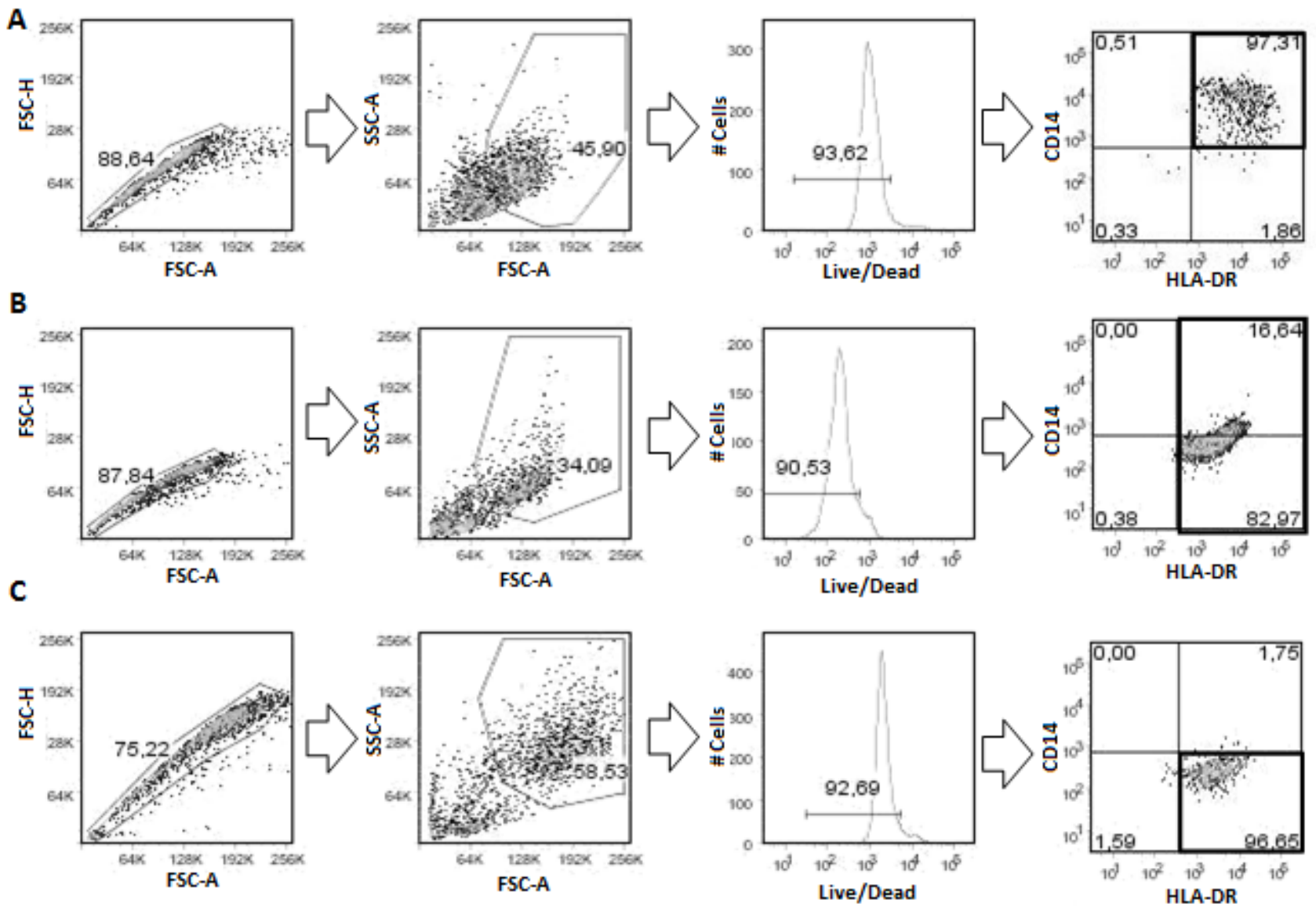

Figura 1 - Estratégia de análise dos dados de citometria de fluxo. Esquema de análise dos marcadores de superfície em (A) monócitos, (B) iDCs e (C) mDCs. Primeiramente excluíram-se da análise os doublets (eventos que se caracterizam pela presença de mais de uma célula). Em seguida, foi feito um gate no tamanho e granulosidade característico da célula a ser analisada. Depois, as células mortas foram excluídas e, por fim, foi feito um gate no gráfico de HLA-DR por CD14, selecionando células positivas para HLA-DR e CD14 para os monócitos, positivas para HLA-DR para as iDCs e positivas para HLA-DR e negativas para CD14 para as DCs.

As células foram marcadas, como descrito em 3.3, com anticorpos monoclonais comerciais específicos para os seguintes marcadores: CD1a (molécula apresentadora de lipídeos), CD40 (molécula necessária para apresentação efetiva de antígenos), CD11c (cadeia alfa $X$ de integrinas, presente em DCs mielóides), CD14 (co-receptor de LPS, presente em monócitos e ausente em DCs), CD80 (B7-1, molécula co-estimuladora), CD83 (marcador de DCs ativadas/maduras), CD274 (PD-L1; molécula reguladora), CD86 (B7-2, molécula co-estimuladora), CD123 (receptor de IL-3, expresso por células plasmocitóides), CCR7 (receptor de quimiocinas que direciona as células para os 
linfonodos), HLA-ABC (moléculas de classe I do MHC) e HLA-DR (molécula de classe II do $\mathrm{MHC})$.

Para análise dos marcadores de membrana, foram feitos quatro gates consecutivos de análise (Figura 1). Primeiramente os eventos que se caracterizavam por uma única célula (singlets) foram selecionados. Em seguida, um gate com as características de cada tipo celular foi delimitado no gráfico de tamanho (FSC - forward scatter) por granulosidade (SSC - side scatter). Depois, as células vivas foram delimitadas, excluindo-se aquelas positivas para o corante de viabilidade LIVE/DEAD® (Invitrogen, Carlsbad, CA, USA). Por último, foi feito um gate no gráfico dos marcadores HLA-DR e CD14, selecionando a população $\mathrm{HLA}^{-D R^{+}} \mathrm{CD}^{+} 4^{+}$para análise dos monócitos, $\mathrm{HLA}-\mathrm{DR}^{+}$para análise das iDCs e HLA-DR ${ }^{+} \mathrm{CD} 14$ para análise das mDCs.

\subsection{Cultura das linhagens tumorais utilizadas}

As linhagens usadas nesse trabalho foram sistematicamente verificadas quanto à presença de micoplasma, sendo usadas em experimento apenas aquelas livres de tal contaminação. A passagem de todas as linhagens também foi controlada durante os experimentos de modo a se usar apenas passagens dentre um intervalo de, no máximo, 10 repiques, diminuindo-se assim a variação genética que pode ocorrer devido ao grande tempo de cultivo.

Todas as linhagens foram cultivadas em meio RPMI-1640 suplementado com $10 \%$ de soro fetal bovino (SFB) (R-10; Sigma, St. Louis, Missouri, USA) acrescido de antibiótico e antimicótico (100 U/ml penicilina, $100 \mu \mathrm{g} / \mathrm{ml}$ estreptomicina e $25 \mu \mathrm{g} / \mathrm{ml}$ anfotericina; Gibco, Carlsbad, CA, USA). Todas as linhagens foram cultivadas em estufa a $37^{\circ} \mathrm{C}$ e $5 \%$ de $\mathrm{CO}_{2}$, porém, as células da linhagem MDA-MB-436 que, por orientação do ATCC, não devem ser cultivadas na presença de $\mathrm{CO}_{2}$, foram cultivadas em garrafas com filtro vedadas. As linhagens que não estavam condicionadas ao meio R-10 tiveram seu meio de origem substituído gradualmente.

Para o experimento de sensibilização de linfócitos T em microculturas, foi utilizada a linhagem de leucemia mieloide crônica, K562, estavelmente expressando HLA-A2 (aqui 
denominada KA2). As linhagens KA2 foram cultivadas em $\mathrm{R}-10$ na presença de geneticina, visando manter a expressão de HLA-A2 nessas células.

\subsection{Fusão de células dendríticas com células tumorais}

No último dia da cultura de células dendríticas, elas foram retiradas da garrafa de cultura, lavadas e ressuspendidas, na concentração de 2 ou $4 \times 10^{6}$ células $/ \mathrm{mL}$, em uma solução de glicose 5\% estéril. As células tumorais (SK-BR-3 ou MDA-MB-231) também foram retiradas da cultura, lavadas e ressuspendidas na solução de glicose $5 \%$ na concentração de 2 ou $4 \times 10^{6}$ células $/ \mathrm{mL}$. Volumes iguais das duas suspensões celulares foram misturadas e colocadas em uma cubeta de $4 \mathrm{~mm}$, sendo submetidas à fusão por um pulso elétrico de $400 \mathrm{~V}$ com $25 \mu \mathrm{F}$, aplicado pelo Gene-Pulser II (BioRad, Richmond, CA, USA), depois de serem alinhados em um campo elétrico heterogêneo $(62.5 \mathrm{~V} / \mathrm{cm})$ por $15 \mathrm{~s}$. Passado um tempo do pulso, as células foram retiradas da cubeta e colocadas em um tampão de relaxamento $(100 \mathrm{mM} \mathrm{KCl}, 3 \mathrm{mM} \mathrm{NaCl}, 1,25$ mM EDTA, $10 \mathrm{mM}$ PIPES, 0,5 mM ATP, pH ajustado para 6,8), sendo mantidas por 5 minutos. Passado 0 tempo as células foram centrifugadas e colocadas em cultura.

Duas adaptações do protocolo acima foram testadas. Na primeira $500 \mu \mathrm{L}$ de cada solução celular na concentração de $2 \times 10^{6}$ células $/ \mathrm{mL}$ foram colocadas na cubeta e imediatamente fundidas, sendo deixadas por 2 minutos antes de serem colocadas em 2 $\mathrm{mL}$ de tampão de relaxamento. Na segunda, $250 \mu \mathrm{L}$ de cada solução celular na concentração de $4 \times 10^{6}$ células $/ \mathrm{mL}$ foram colocados na cubeta e após 5 minutos as células foram fundidas. Após mais 5 minutos, as células foram colocadas em $500 \mu \mathrm{L}$ de solução de relaxamento.

\subsection{Análise da porcentagem de híbridos formados pelo processo de fusão}

Para analisar a quantidade de híbridos gerados entre células dendríticas e células tumorais, as células foram marcadas, antes da eletroporação, com um corante vermelho e verde, respectivamente, ou posteriormente marcadas com dois anticorpos específicos, sendo um para a célula tumoral e outro para a célula dendrítica. Após a fusão, avaliou-se 
a porcentagem de células positivas para os dois corantes ou para os dois marcadores de membrana.

Para análise da formação de híbridos por marcadores de membrana, as células foram marcadas como descrito em 3.3, depois de fundidas, com Her2/neu e HLA-DR (quando usadas células da linhagem SK-BR-3) ou com Her2/neu e CD11c (no caso da fusão com a linhagem MDA-MB-231, que expressa HLA-DR).

No caso da análise por corantes, células dendríticas maduras foram retiradas da garrafa de cultura, centrifugadas e ressuspendidas em PBS com 0,5\% de soroalbumina bovina na concentração de $1 \times 10^{6}$ células $/ \mathrm{mL}$. Em seguida, foi adicionado o CellTracker ${ }^{\mathrm{TM}}$ Red CMPTX (Red; Invitrogen) na concentração final de $2 \mu \mathrm{M}$. As células foram, então, incubadas em estufa por 15 min, centrifugadas, e deixadas por 30 minutos em meio AIM-V para permitir que ocorra a reação que irá manter o corante dentro da célula. $O$ mesmo procedimento foi utilizado para corar células de linhagens tumorais. O corante usado, porém, foi o CellTracker ${ }^{\mathrm{TM}}$ Green CMFDA (Green; Invitrogen), na concentração de 0,8 $\mu \mathrm{M}$. Como alternativa ao corante vermelho, que apresentou baixa marcação em alguns experimentos, também foi usado o corante CellTrace ${ }^{\mathrm{TM}}$ Violet (Violet; Invitrogen). Após a marcação das duas células, a fusão foi realizada como descrito em 3.6.

A análise das células duplo-positivas foi feita por microscopia de fluorescência, microscopia confocal ou citometria de fluxo.

\subsection{Imunofluorescência}

As células a serem analisadas por imunofluorescência foram marcadas conforme descrito em 3.3 e fixadas com paraformaldeído 4\% por 60 min à temperatura ambiente. Em seguida, as células foram colocadas em reagente Prolong Gold Antifade com DAPI (Invitrogen) e vedadas sobre a lâmina. As fotos foram adquiridas no microscópio de fluorescência Nikon Eclipse Ti-S (Nikon, Melville, NY, USA) com o software NISElements AR (Nikon) ou no microscópio confocal multifoton Zeiss LSM 780 (Zeiss, Oberkochen, Germany) com o ZEN confocal software (Zeiss). 


\subsection{Análise fenotípica dos híbridos de células dendríticas e células tumorais}

Os híbridos foram marcados, como descrito em 3.3, com anticorpos para moléculas importantes para atuação das células dendríticas e com anticorpo para Her2/neu. A análise dos marcadores foi realizada tanto na população total quanto apenas nas células positivas para os dois corantes celulares ou os dois marcadores de membrana específicos descritos no item 3.7, excluindo da análise as células que não tenham fundido, ou os híbridos que não foram formados entre os dois tipos celulares.

\subsection{Ensaio de proliferação de linfócitos T}

A obtenção de linfócitos T purificados foi feita utilizando-se seleção negativa com beads magnéticas (Miltenyi Biotec), conforme protocolo descrito pelo fabricante. Linfócitos $T$ autólogos ou alogeneicos às células dendríticas utilizadas para formação dos híbridos com células tumorais foram ressuspendidos em PBS com $0,5 \%$ de soroalbumina bovina pré-aquecido ajustando-se a concentração para $1 \times 10^{7}$ células $/ \mathrm{mL}$. Para cada $\mathrm{mL}$ de células, adicionou-se $2 \mu \mathrm{L}$ de CFSE $5 \mathrm{mM}$, incubando-se a mistura por $10 \mathrm{~min}$ a $37{ }^{\circ} \mathrm{C}$ no escuro. Em seguida, a amostra foi diluída adicionando-se $5 \mathrm{~mL}$ de R-10 gelado. $\mathrm{O}$ tubo foi, então, incubado no gelo por $5 \mathrm{~min}$. Em seguida, as células foram lavadas duas vezes com $\mathrm{R}-10$ a $800 \mathrm{~g}$ por 7 min, e ressuspendidas em R-10 na concentração a ser usada na co-cultura.

Os linfócitos T marcados foram, então, co-cultivados por 5 dias, na proporção de 10:1, com os híbridos de células dendríticas e células tumorais, previamente irradiados ou não com $200 \mathrm{~Gy}$, em placas de 96 poços, fundo em U. Ao término da cultura a diluição do CFSE foi avaliada por citometria de fluxo.

\subsection{Sensibilização de linfócitos T em macroculturas}

Células não aderentes autólogas às células dendríticas utilizadas para formação dos híbridos com células tumorais foram plaqueadas em placas de 24 poços, na proporção de $10: 1$, com $2 \times 10^{5}$ híbridos de células dendríticas e células da linhagem 
MDA-MB-231 irradiados com 200 Gy. O meio de cultura R-10 foi suplementado no dia zero da cultura com IL-7 $(5 \mathrm{ng} / \mathrm{mL})$. Ao segundo e quinto dia de cultura, o meio foi trocado por R-10 suplementado com IL-7 $(5 \mathrm{ng} / \mathrm{mL})$ e IL-2 $(0,5 \mathrm{ng} / \mathrm{mL})$. Após 7 dias de cultura, os linfócitos $T$ foram retirados, contatos e reestimulados com híbridos de células dendríticas e células tumorais, mantendo-se a proporção de 10:1. O segundo estímulo foi feito com híbridos que foram gerados a partir de DCs do mesmo doador, que foram descongeladas e fundidas com células tumorais no dia do reestímulo, e irradiadas com 200 Gy. O meio foi suplementado com IL-7 e IL-2 da mesma maneira como foi feito no primeiro estímulo. Após 7 dias do reestímulo, as células foram retiradas da cultura e os linfócitos T foram purificados para serem utilizados no ensaio de citotoxicidade.

\subsection{Ensaio de citotoxicidade}

Diferentes concentrações de linfócitos $T$, purificados do ensaio de sensibilização em macrocultura, foram colocados em contato com células tumorais alvo em tubos de $1,5 \mathrm{~mL}$. Os tubos foram centrifugados por $10 \mathrm{~s}$ a $13000 \mathrm{rpm}$ e mantidos em estufa de $\mathrm{CO}_{2}$ a $37^{\circ} \mathrm{C}$ por $4 \mathrm{~h}$. Após a incubação, as células foram marcadas com Her2/neu, iodeto de propídio (PI) e anexina V. A leitura foi feita imediatamente após a marcação no citômetro FACSCalibur.

A análise da citotoxicidade foi feita analisando a porcentagem de células positivas para PI dentro das células positivas para Her2/neu, excluindo, assim, as células efetoras da análise. A marcação com anexina $V$ não foi utilizada na análise, uma vez que as células tumorais, por apresentarem fosfatidilserina na parte externa da membrana, marcaram para anexina $\mathrm{V}$ mesmo na ausência de morte. A leitura do PI foi feita pelo canal FL3 do citômetro de fluxo, diminuindo a possível interferência com o fluorocromo FITC que estava conjugado à anexina V. A porcentagem de citotoxicidade foi determinada pela fórmula:

$$
\% \text { de citotoxicidade }=\left(\frac{\% \text { de células alvo PI positivas }-\% \text { de morte esponânea }}{100-\% \text { de morte espontânea }}\right) * 100
$$

sendo que a morte espontânea foi aquela observada na ausência de células efetoras. 


\subsection{Análise fenotípica de linfócitos T}

Os seguintes marcadores foram avaliados nos linfócitos sensibilizados no ensaio de macrocultura: CD3 (marcador específico de linfócitos T), CD4 (subpopulação de linfócitos T), CD8 (subpopulação de linfócitos T), CD25 (cadeia alfa do receptor da IL-2), CD45RA (linfócitos T naïve), CD45RO (linfócitos T de memória) e PD-1 (receptor que regula negativamente a ativação de linfócitos $\mathrm{T}$ ), CD62L ( $\mathrm{L}$-selectina; responsável pelo direcionamento de linfócitos $T$ naïve para os linfonodos), CD69 (molécula coestimuladora; uma das primeiras moléculas a ser expressa após ativação dos linfócitos T) e CD38 (molécula multifuncional expressa em timócitos e linfócitos $T$ ativados). A marcação para essas moléculas foi feita como descrito no item 3.3.

\subsection{Marcação intracelular para análise de fatores de transcrição linfocitários}

Após a marcação com os anticorpos para moléculas de superfície, os linfócitos obtidos do ensaio de sensibilização em macrocultura foram permeabilizados e marcados com anticorpos para os fatores de transcrição específicos de cada subtipo efetor e regulador de células $\mathrm{T} \mathrm{CD}^{+}$.

As células foram centrifugadas a $13000 \mathrm{rpm}$ por $20 \mathrm{~s}$ e ressuspendidas em $300 \mu \mathrm{L}$ de solução permeabilizadora/fixadora diluída 1:4 (eBioscience, San Diego, CA, EUA) e incubadas por 30 minutos a $4{ }^{\circ} \mathrm{C}$ no escuro. Após a incubação, as células foram lavadas duas vezes com $300 \mu \mathrm{L}$ de tampão para lavagem (SFB diluído em água Milli-Q) sendo centrifugadas a 13000 rpm por 20 segundos. Os linfócitos foram, então, incubados por 30 min à temperatura ambiente com a quantidade adequada dos anticorpos para os fatores de transcrição Foxp3 (Treg), T-bet (Th1), GATA-3 (Th2), RORyt (Th17) e para os isotipos controle. As células foram, então, lavadas por mais duas vezes, ressuspendidas em tampão para citometria, e lidas imediatamente após a marcação no citômetro de fluxo. Foram consideradas positivas as marcações que foram superiores à obtida com os respectivos anticorpos de isotipo controle. 


\subsection{Análise de produção de citocinas solúveis por CBA}

O tipo e a quantidade das citocinas produzidas nos ensaios de proliferação e sensibilização em macrocultura foram avaliados pela técnica de CBA (do inglês, Cytometric Bead Array), segundo orientações do fabricante (BD Bioscience). Para tal, as beads de captura foram misturadas com anticorpos de detecção conjugados com ficoeritrina (PE), sendo incubados com o sobrenadante obtido dos ensaios para formação dos complexos. Os dados foram obtidos por citometria de fluxo e analisados com software FCAP Array (BD Bioscience).

\subsection{Sensibilização de linfócitos $\mathrm{T} C D 8^{+}$em microculturas}

A estimulação de linfócitos $\mathrm{T} \mathrm{CD}^{+}$foi feita conforme previamente descrito (SUNDARASETTY, SINGH, et al., 2013). Linfócitos T CD8 ${ }^{+}$foram purificados das células CD14 obtidas após isolamento dos monócitos utilizando microbeads (Miltenyi Biotec). A fração CD8 obtida após esse isolamento foi utilizada com células alimentadoras (do inglês, feeder cells) após serem gama-irradiadas com 45 Gy. Para cada poço da placa de 96 poços com fundo em $U, 1 \times 10^{5}$ linfócitos $\mathrm{T} \mathrm{CD}^{+}, 1 \times 10^{4}$ híbridos de células tumorais

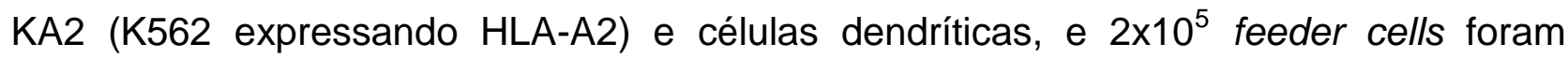
plaqueados em um volume final de $200 \mu \mathrm{L}$ de meio X-VIVO (Lonza) suplementado com $5 \%$ de soro humano AB. O meio foi também suplementado com IL-2 (25 IU $/ \mathrm{mL})$, IL-7 (5 $\mathrm{ng} / \mathrm{mL})$, e IL-15 ( $5 \mathrm{ng} / \mathrm{mL})$, sendo reposto a cada dois dias. As células foram mantidas em estufa com $5 \%$ de $\mathrm{CO}_{2}$ e $37{ }^{\circ} \mathrm{C}$ por 12 dias, sendo reestimuladas em uma placa de 96 poços com fundo chato após 7 dias, com o número apropriado de híbridos de células dendriticas e células tumorais, recém preparados e irradiados, mantendo a proporção de 10:1.

\subsection{Análise da especificidade de linfócitos T CD8 utilizando pentâmeros}

Linfócitos $\mathrm{T}\left(4 \times 10^{5}\right.$ células por teste) obtidos do ensaio de sensibilização em microcultura foram marcados com um pentâmero de HLA-A02 específico para pp65 
(NLVPMVATV), um pentâmero de HLA-B07 específico para pp65 (TPRVTGGGAM) ou um pentâmero inespecífico por 30 min no escuto a $4{ }^{\circ} \mathrm{C}$ em $50 \mu \mathrm{L}$ de PBS suplementado com $0.5 \%$ de soroalbumina bovina. Os linfócitos $T$ também foram marcados com anticorpos CD8 conjugados com FITC e CD3 conjugados com PeCy7. As células foram lavadas com PBS suplementado com $0.5 \%$ de soroalbumina bovina, ressuspendidas no mesmo tampão e mantidas no gelo até a aquisição. A análise foi feita delimitando, consecutivamente, as células únicas (singlets), células vivas, células $C D 3^{+} C D 8^{+}$e então analisando a porcentagem de células $\mathrm{CD}^{+}$que se ligaram ao pentâmero (Figura 2).
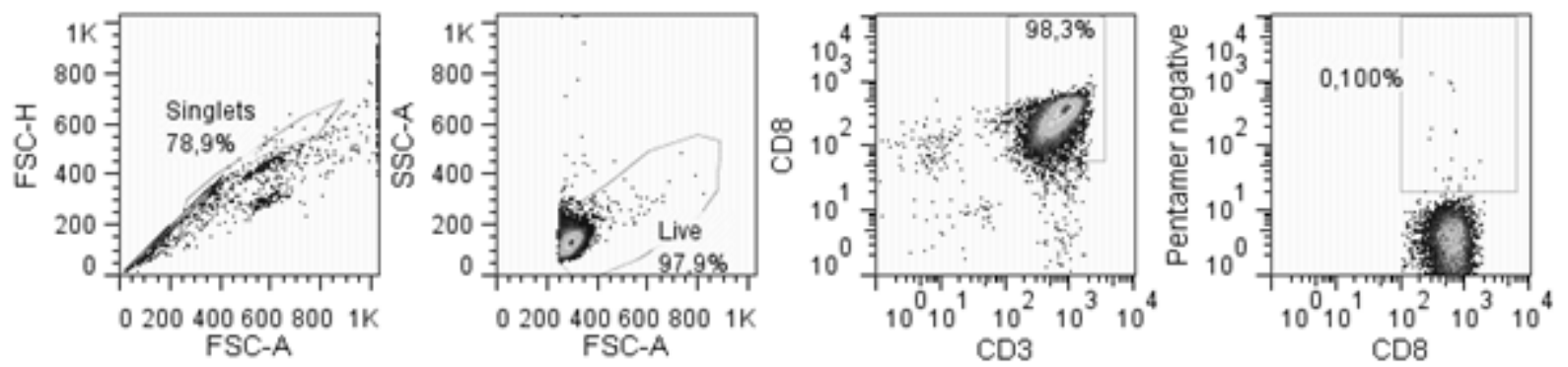

Figura 2 - Estratégia de análise da marcação com pentâmeros. Primeiramente os singlets foram delimitados, excluindo-se os doublets da análise. Em seguida, foi feito um gate no tamanho e granulosidade característico de linfócitos vivos. Dentro das células vivas, selecionaram-se aquelas duplo-positivas para CD3 e CD8. Por fim, a porcentagem de células positivas para o tetrâmero foi determinada entre as células positivas para CD8.

\subsection{ELISPOT}

A capacidade dos linfócitos T CD8 ${ }^{+}$sensibilizados no ensaio de microcultura em produzir IFN-y após um estímulo específico foi testada incubando-se essas células com células KA2, KA2/pp65 ou pp65 pepmix (uma mistura de peptídeos gerada a partir da clivagem da proteína pp65). Como controle negativo, as células foram incubadas sem nenhum outro estímulo, e como controle positivo foram incubadas com CEF, uma mistura de peptídeos contendo 32 epítopos restritos pelas moléculas de classe I do MHC e específicos para três diferentes vírus: citomegalovírus humano, vírus Epstein-Barr e influenza. $2,5 \times 10^{4}$ células $T$ foram misturadas com $5 \times 10^{5}$ células alvo por poço e incubadas por 20 horas em estufa a $37^{\circ} \mathrm{C}$ e $5 \% \mathrm{CO}_{2}$. Após incubação, as células foram 
descartadas e as placas foram incubadas com anticorpo anti IFN- $\gamma$ conjugado com biotina. As placas foram desenvolvidas utilizando substrato líquido NBT/BCIP (Sigma), analisadas em um leitor de ELISPOT (CTL Immunospot analyzer) e quantificadas com o Software ImmunoSpot ${ }^{\circledR}$ (CTL-Europe $\left.\mathrm{GmbH}\right)$.

\subsection{Extração de RNA}

A extração de RNA foi feita com 2 a $10 \times 10^{5}$ células tumorais, utilizando-se ou a técnica de extração por Trizol, ou um kit de extração comercial da Quiagen (RNeasy Plus Mini Kit). A extração com kit, que consiste em uma etapa de eliminação de DNA genômico seguida da separação do RNA total, foi feita conforme protocolo do fabricante.

A extração por trizol foi feita adicionando-se ao tubo com as células $1 \mathrm{~mL}$ de Trizol $^{\circledR}$ (Invitrogen) e ressuspendendo as células vigorosamente com auxílio de pipeta. As amostras foram, em seguida, incubadas por $5 \mathrm{~min}$ a temperatura ambiente para a completa dissociação dos complexos nucleoprotéicos. Em seguida, $200 \mu \mathrm{L}$ de clorofórmio foram adicionados a cada amostra. Os tubos foram agitados manualmente de forma vigorosa por $15 \mathrm{seg}$, sendo posteriormente incubados de 2 a $3 \mathrm{~min}$ a temperatura ambiente. Após esse período, as amostras foram centrifugadas a $12000 \mathrm{~g}$ por $15 \mathrm{~min}$ a $4{ }^{\circ} \mathrm{C}$. Após centrifugação, observou-se a formação de uma fase aquosa incolor na parte superior do líquido que foi transferida para outro tubo, uma vez que é nessa camada que se encontra o RNA. O RNA foi precipitado adicionando-se $500 \mu \mathrm{L}$ de álcool isopropílico no tubo e o incubado por $10 \mathrm{~min}$ a temperatura ambiente. Em seguida, as amostras foram centrifugadas a $12000 \mathrm{~g}$ por $10 \mathrm{~min}$ a $4{ }^{\circ} \mathrm{C}$. O sobrenadante foi removido e o sedimento lavado com $1 \mathrm{~mL}$ de etanol a $75 \%$ em água DEPC, sendo centrifugado a $7500 \mathrm{~g}$ por $5 \mathrm{~min}$ a $4{ }^{\circ} \mathrm{C}$. O sobrenadante foi novamente removido e as amostras foram mantidas em temperatura ambiente até completa evaporação do etanol. Por fim, o RNA foi dissolvido em água DEPC sendo armazenado a $-80{ }^{\circ} \mathrm{C}$ para posterior utilização.

O RNA total obtido pelos dois métodos foi quantificado pelo espectrofotômetro NanoDrop ND-1000 e a integridade do RNA extraído foi avaliada através de uma eletroforese em gel de agarose 1,5\% corado com GelRed ${ }^{\mathrm{TM}}$ Nucleic Acid Gel Stain 
(Biotium). A observação de duas bandas fortes correspondentes aos RNAs das subunidades ribossomais $18 \mathrm{~S}$ e $28 \mathrm{~S}$ confirma a integridade do RNA (Figura 3).

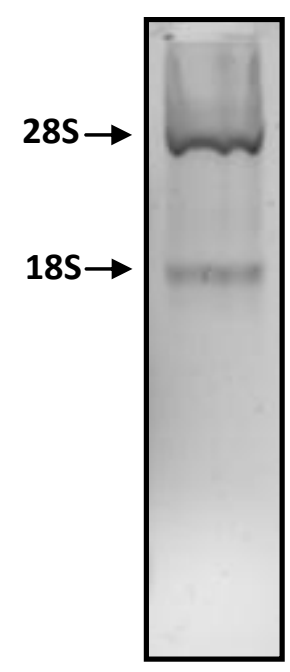

Figura 3 - Fotografia da eletroforese em gel de agarose do produto de extração de RNA total. O produto de extração de RNA de células tumorais foi submetido à eletroforese em gel de agarose $1,5 \%$, onde se evidenciou o padrão de migração do RNA das subunidades ribossomais $18 \mathrm{~S}$ e $28 \mathrm{~S}$.

\subsection{Transfecção de linhagens tumorais com mRNA tumoral}

As linhagens tumorais MCF-7 e MDA-MB-231 foram submetidas a um processo de transfecção reversa com diferentes agentes de transfecção lipídicos. As melhores condições de transfecção foram testadas adicionando ao mRNA tumoral, 10\% de mRNA que codifica a proteína verde fluorescente (GFP).

Para cada grupo, $5 \mu \mathrm{L}$ do agente de transfecção - na maioria dos casos a Lipoanfectamina (Lipofectamine $\AA 2000$, Invitrogen) - foram diluídos em $95 \mu \mathrm{L}$ de meio Opti-MEM® (Invitrogen) e 1 a 2,5 $\mu \mathrm{g}$ de RNA foram diluídos em $100 \mu \mathrm{L}$ de Opti-MEM. Então, as duas soluções foram misturadas, incubadas a temperatura ambiente por 30 min e colocadas em placas de 6 poços. As células tumorais foram retiradas das garrafas de cultura e ressuspendidas em RPMI-1640. Para cada tratamento, $5 \times 10^{5}$ células (que foram ressuspendidas em $1,3 \mathrm{~mL}$ de meio) foram colocadas na placa de 6 poços tratada previamente com $200 \mu \mathrm{L}$ do complexo lipídico. Quatro horas após a transfecção, as células tiveram seu meio trocado por R-10. 


\subsection{Transcrição reversa (RT-PCR) para detecção de sequências específicas}

Para detecção de sequências específicas por PCR e qPCR é necessário apenas a transcrição reversa da fita complementar do mRNA, formando assim, moléculas de mRNA/cDNA dupla fita, que são passíveis de amplificação por esses métodos.

Para gerar o duplex, $1 \mu \mathrm{g}$ de RNA foi diluído para um volume final de $11 \mu \mathrm{L}$ e incubado com $1 \mu \mathrm{L}$ de primer oligo- $\mathrm{dT}_{18}\left(50 \mu \mathrm{M}\right.$, Invitrogen) a $70{ }^{\circ} \mathrm{C}$ por 3 min para anelamento. Em seguida, com a temperatura em $4{ }^{\circ} \mathrm{C}$, adicionou-se uma mistura contendo $1 \mu \mathrm{L}$ de DTT (0,1 M), $2 \mu \mathrm{L}$ de dNTPs a 2,5 mM (Invitrogen), $1 \mu \mathrm{L}$ da enzima SuperScript ${ }^{\circledR}$ III Reverse Transcriptase (200 U/ $\mathrm{L}$, Invitrogen) e $4 \mu \mathrm{L}$ de seu tampão 5x. A extensão foi feita a $42{ }^{\circ} \mathrm{C}$ por 60 min e a reação foi inativada a $92{ }^{\circ} \mathrm{C}$ por $10 \mathrm{~min}$.

\subsection{Desenho dos primers usados nas reações de PCR e qPCR}

Tabela 2 - Sequências dos primers para PCR e qPCR. Sequências dos primers forward $(F)$ e reverse $(R)$ e números de identificação das sequências de cDNA do banco de dados do NCBI que foram utilizadas para o desenho dos primers.

\begin{tabular}{|c|c|c|}
\hline Gene & Sequência & \# NCBI \\
\hline \multirow[t]{2}{*}{$\beta 2$-microglobulina } & F5'- GAGGCTATCCAGCGTACTCCA -3' & NM_004048.2 \\
\hline & R5'- CGGCAGGCATACTCATCTTTTT -3' & \\
\hline \multirow[t]{2}{*}{ HLA-DR } & F5'- GGTGGAGCACTGGGGCTTGG -3' & NM_019111.3 \\
\hline & R5'- ACAGAGGCCCCCTGCGTTCT -3' & \\
\hline \multirow[t]{2}{*}{ HLA-A } & F5'- GATTACATCGCCTTGAACGAGG -3' & NM_002116.7 \\
\hline & R5'- AGAGACAGCGTGGTGAGTCAT -3' & \\
\hline \multirow[t]{2}{*}{ Her2/neu (ERBB2) } & F5'- TGCAGGGAAACCTGGAACTC -3' & NM_001005862.1 \\
\hline & R5'- ACAGGGGTGGTATTGTTCAGC -3' & \\
\hline \multirow[t]{2}{*}{ Era } & F5'- CCCACTCAACAGCGTGTCTC -3' & NM_001122741.1 \\
\hline & R5'- CGTCGATTATCTGAATTTGGCCT -3' & \\
\hline \multirow[t]{2}{*}{ PR } & F5'- ACCCGCCCTATCTCAACTACC -3' & NM_000926 \\
\hline & R5'- AGGACACCATAATGACAGCCT -3' & \\
\hline \multirow[t]{2}{*}{$\beta$-actina } & F5'- ACGAAACTACCTTCAACTCCATCAT -3' & NM_001101.3 \\
\hline & R5'- ATGATCTTGATCTTCATTGTGCTG-3' & \\
\hline
\end{tabular}


Os primers foram desenhados com base em sequências de referência depositadas no NCBI (http://www.ncbi.nlm.nih.gov) e sua especificidade foi testada com um software de PCR in sílico (http://genome.ucsc.edu/cgi-bin/hgPcr) (Tabela 2).

É importante observar que os primers para a molécula HLA-DR, que é composta por duas cadeias, amplificam a cadeia alfa da proteína. Os primers para Her2/neu foram desenhados para amplificar uma região idêntica das duas isoformas do receptor. Os primers para o receptor de estrógeno $(E R)$ amplificam apenas a isoforma alfa desse receptor. Os primers para o receptor de progesterona (PR) foram desenhados para amplificar uma região idêntica das variantes transcricionais $A, B$ e $D$ do receptor.

\subsection{PCR convencional}

Para cada reação de PCR, foi feita uma mistura $(25 \mu \mathrm{L})$ consistindo de: $2,5 \mu \mathrm{L}$ do tampão (10X), 0,75 $\mu \mathrm{L}$ de $\mathrm{MgCl}_{2}$ (50 mM), 2,0 $\mu \mathrm{L}$ de dNTPs a 2,5 mM (Invitrogen), 1,25

$\mu \mathrm{L}$ de cada primer (10 pmol/ $\mu \mathrm{L}), 0,2 \mu \mathrm{L}$ da enzima Taq DNA Polimerase (Invitrogen) (5 $\mathrm{U} / \mu \mathrm{L}$ ) e $1 \mu \mathrm{L}$ do cDNA. A reação foi realizada no termociclador utilizando uma desnaturação inicial a $94^{\circ} \mathrm{C}$ por 3 min, seguido de 35 ciclos de desnaturação a $94^{\circ} \mathrm{C}$ por $45 \mathrm{~s}$, anelamento a $60{ }^{\circ} \mathrm{C}$ por $30 \mathrm{~s}$ extensão a $72{ }^{\circ} \mathrm{C}$ por $60 \mathrm{~s}$, com uma extensão final a $72{ }^{\circ} \mathrm{C}$ por $10 \mathrm{~min}$. Em seguida, foi realizada uma eletroforese em gel de agarose 1,5\% corado com GelRed $^{\mathrm{TM}}$ Nucleic Acid Gel Stain com o produto da PCR, visualizando-se a presença ou ausência da banda correspondente ao produto esperado.

\subsection{PCR em tempo real (qPCR)}

Para a reação de PCR em tempo real (qPCR) utilizou-se o kit SYBR® Green PCR Master Mix (Applied Biosystems). A reação de qPCR foi padronizada para os primers descritos na Tabela 2, garantindo a amplificação específica do produto de interesse, conforme observado pelas curvas de dissociação de cada um dos genes (Figura 4).

Cada reação $(12,5 \mu \mathrm{L})$ foi composta por $6,25 \mu \mathrm{L}$ de SYBR, 4,5 $\mu \mathrm{L}$ de água ultrapura, $0,375 \mu \mathrm{L}$ de cada primer $(10 \mathrm{pmol} / \mu \mathrm{L})$ e $1 \mu \mathrm{L}$ de cDNA. As condições para a reação foram: $95{ }^{\circ} \mathrm{C}$ por 10 min para a ativação da enzima AmpliTaq Gold DNA 
Polimerase presente no SYBR mix, 40 ciclos de desnaturação a $95{ }^{\circ} \mathrm{C}$ por $15 \mathrm{~s}$, anelamento e extensão a $60^{\circ} \mathrm{C}$ por 1 min, seguido da curva de dissociação $\left(95^{\circ} \mathrm{C}\right.$ por 1 min, $60^{\circ} \mathrm{C}$ por $30 \mathrm{~s} \mathrm{e} 95^{\circ} \mathrm{C}$ por $30 \mathrm{~s}$ ). A reação de qPCR foi realizada no equipamento Stratagene Mx3000P QPCR System utilizando o software MxPro ${ }^{T M} 3.0$.
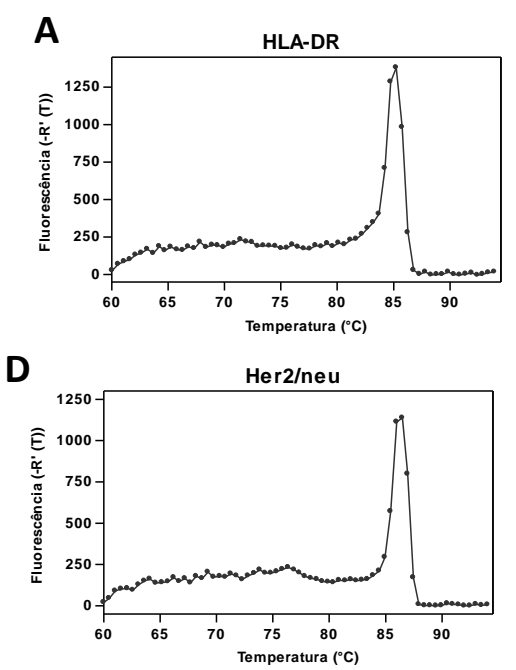

B

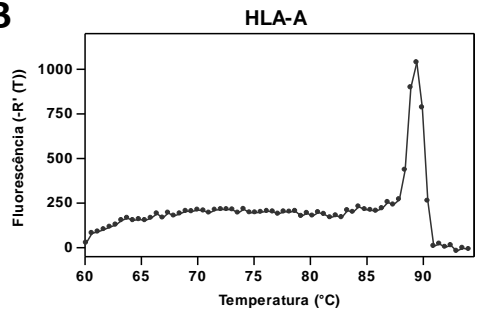

E

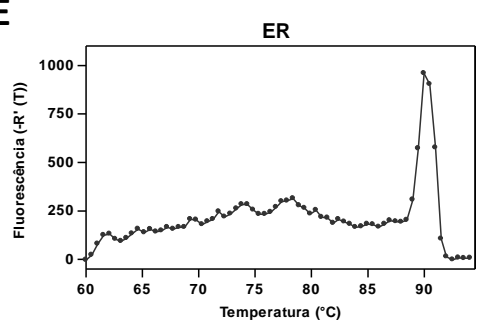

C

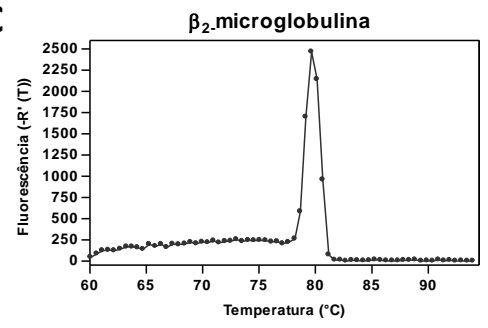

$\mathbf{F}$

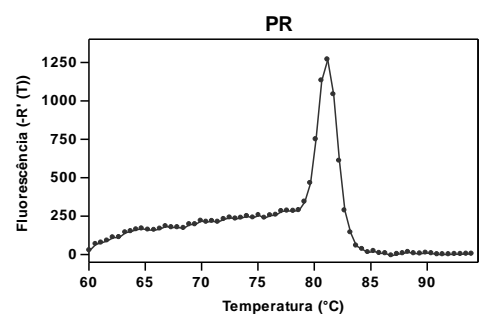

Figura 4 - Especificidade da reação de PCR em tempo real. Curvas de dissociação do produto da reação de PCR em tempo real com pares de primers específicos para amplificar (A) HLA-DR , (B) HLA-A, (C) $\beta_{2}$-microglobulina, (D) Her2/neu, (E) ER e (F) PR.

A expressão relativa dos genes alvos foi analisada pelo método do $2^{-\Delta \Delta C T}$ (LIVAK e SCHMITTGEN, 2001). Segundo este método, deve-se subtrair o Ct (Threshold cicle) da amostra de interesse pelo $\mathrm{Ct}$ do gene constitutivo dessa mesma amostra, no caso, $\beta$-actina, dando origem a um valor de $\Delta \mathrm{Ct}$. Em seguida, calcula-se o $\Delta \Delta \mathrm{Ct}$, que trata da diferença entre o valor de $\Delta \mathrm{Ct}$ de uma amostra em questão e o $\Delta \mathrm{Ct}$ de uma amostra calibradora, a partir da qual todas as amostras farão referência. Por fim, calcula-se o valor de $2^{-\Delta \Delta C t}$, obtendo-se, assim, a expressão relativa do gene de interesse. Este método parte do princípio de que a eficiência da reação de amplificação do gene alvo é igual à do gene constitutivo, ambas próximas de 100\%. O teste de eficiência de amplificação foi feito para todos os primers usados e, após constatação de eficiências acima de $90 \%$, foi possível eleger esse método de análise. 


\subsection{Transcrição reversa (RT-PCR) e amplificação do RNA total via PCR}

A reação de transcrição reversa deve ser feita de modo a formar cDNAs de comprimento completo, uma vez que a perda de parte da sequência do mRNA, mesmo em regiões não traduzidas (UTR; do inglês, untranslated region), pode interferir no processo de tradução que se espera ocorrer in vivo. Sendo assim, para sintetizar a primeira fita do cDNA, foi usado um primer composto de um oligonucleotídeo de desoxitiminas (oligo-dT), que é capaz de se anelar a cauda poli-A dos mRNAs, com uma sequência adicional (3' PCR). A segunda fita foi sintetizada levando-se em consideração que a transcriptase reversa adiciona três ou quatro resíduos de desoxicitidina $(\mathrm{dC})$ na extremidade 5' do cDNA. Sendo assim, para extensão da segunda fita do cDNA, utilizouse um primer que contém uma pequena sequência de desoxiguanosina ( $d G$ ) e a sequência complementar do sítio promotor de T7 (Figura 5, Tabela 3).

Tabela 3 - Sequência dos primers que foram usados para produção e amplificação do cDNA a partir do mRNA tumoral total. $V=G, A$ ou $C . N=G, T, A$ ou $C$.

\begin{tabular}{ll}
\hline \hline Primer & Sequência \\
\hline oligo-dT modificado & 5'-AAGCAGTGGTATCAACGCAGAGTACT ${ }_{(30)} \mathrm{VN}^{\prime}$ 3' $^{\prime}$ \\
T7 modificado & 5'-CTAATACGACTCACTATAGGGCGGG-3' \\
T7 PCR & 5'-CCATCCTAATACGACTCACTATAGGGC-3' \\
3' PCR & 5'- AAGCAGTGGTATCAACGCAGAGT-3 \\
\hline
\end{tabular}

Para obtenção da primeira fita do cDNA, $1000 \mathrm{ng}$ do RNA total foram submetidas a transcrição reversa com $10 \mathrm{pmol}$ do primer oligo-dT modificado (IDT - Integrated DNA Technologies, Coralville, IA, USA) e $4 \mu \mathrm{L}$ de dNTPs a 2,5 mM (Invitrogen) em um volume final de reação de $20 \mu \mathrm{l}$. Essa mistura foi incubada a $70{ }^{\circ} \mathrm{C}$ por $15 \mathrm{~min}$, sendo em seguida refrigerada a $4{ }^{\circ} \mathrm{C}$ por $5 \mathrm{~min}$. Durante esse período foi adicionada uma mistura contendo 200 unidades da enzima de transcrição reversa SuperScript III (Invitrogen), $4 \mu \mathrm{L}$ do seu tampão 5x, $1 \mu \mathrm{L}$ de DTT 0,1 M (Invitrogen), e 40 unidades de RNAse OUT (Invitrogen). Em seguida, a reação foi mantida a $25{ }^{\circ} \mathrm{C}$ por 5 min, e depois por mais 1 hora a $42{ }^{\circ} \mathrm{C}$. Após esse tempo de reação, para obtenção da fita complementar, foram adicionados 10 
pmol do primer T7 modificado (IDT, San Jose, CA, EUA) e a reação foi mantida por mais 1 hora a $42^{\circ} \mathrm{C}$. A inativação da reação foi feita a $70^{\circ} \mathrm{C}$ por $15 \mathrm{~min}$.

\section{A Transcrição reversa do mRNA}
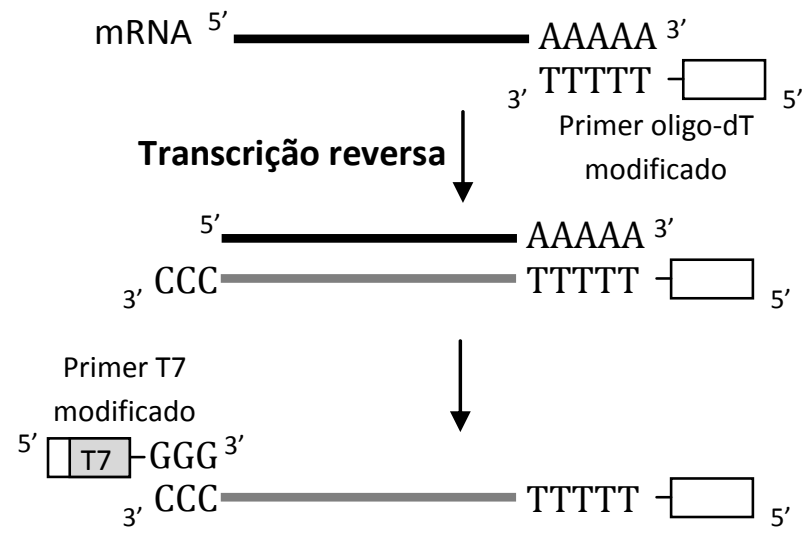

Transcrição reversa

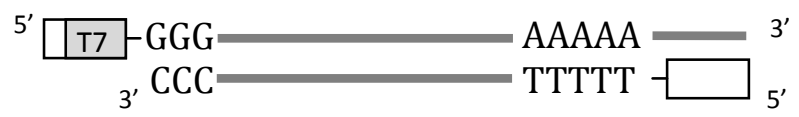

B Amplificação do cDNA
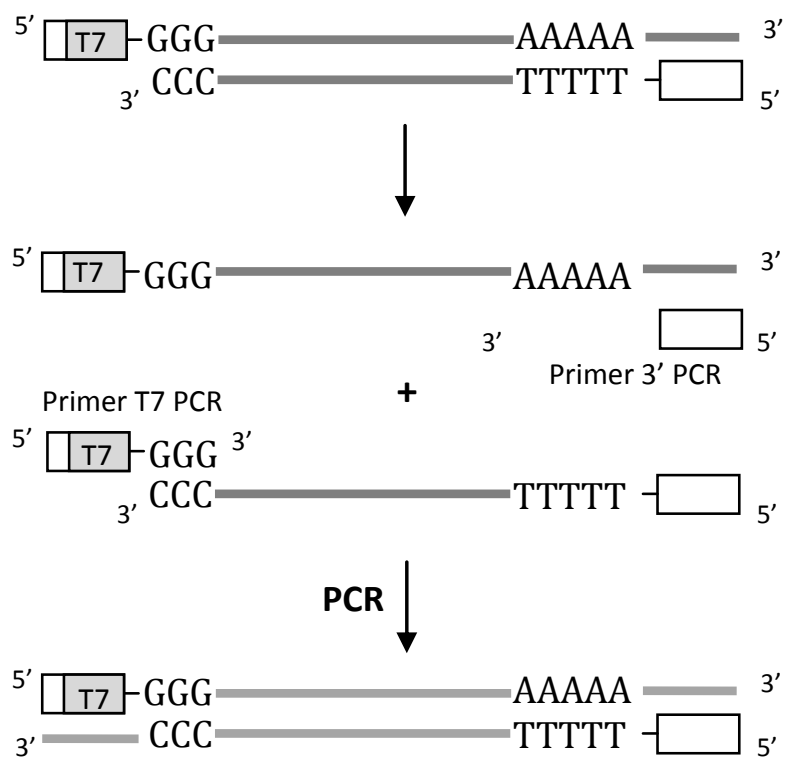

Figura 5 - Esquema do método de amplificação do mRNA. (A) O RNA extraído foi submetido à transcrição reversa com uma enzima que adiciona três ou quatro resíduos de $\mathrm{C}$ no final da fita nascente, usando como primer um oligonucleotídeo contendo resíduos de $\mathrm{T}$ e uma sequencia de 23 nucleotídeos necessária para a amplificação

(oligo-dT modificado). Um segundo oligonucleotídeo contendo a sequencia complementar do promotor T7 e 3 resíduos de G (primer T7 modificado) foi usada para produzir a segunda fita do cDNA. (B) Para amplificar o cDNA foi usada uma enzima de alta fidelidade, o primer 3' que anela na região acrescentada pelo oligo-dT modificado e o primer T7 que se anela na região acrescentada pelo primer T7 modificado.

A amplificação do cDNA foi feita pela adição de $2 \mu$ do produto da reação de transcrição reversa em $50 \mu$ de volume final da reação de PCR contendo 20 pmol dos primers T7 PCR e 3' PCR (IDT). As condições de amplificação foram adaptadas para a enzima Taq High Fidelity DNA polymerase (Invitrogen) com adição de 2,5 unidades da enzima com $5 \mu \mathrm{L}$ do seu tampão 10x, $4 \mu \mathrm{L}$ de dNTPs a 2,5 mM (Invitrogen) e 1,5 $\mu \mathrm{L}$ de $\mathrm{MgCl}_{2}$ para uma concentração final de $1,5 \mathrm{mM}$. 
A reação foi realizada mantendo a amostra por 2 min de desnaturação inicial a $94{ }^{\circ} \mathrm{C}$ e 35 ciclos de $94{ }^{\circ} \mathrm{C}$ por $30 \mathrm{~s}$ para desnaturação, $60{ }^{\circ} \mathrm{C}$ por $30 \mathrm{~s}$ para anelamento, e $68^{\circ} \mathrm{C}$ por 3 min para extensão. A inativação da reação foi feita a $72{ }^{\circ} \mathrm{C}$ por 10 minutos.

A reação de PCR foi alterada após constatação de que o RNA não estava sendo amplificado em sua integridade. As condições de ciclagem alteradas consistiram de uma desnaturação inicial a $95{ }^{\circ} \mathrm{C}$ por 1 min e 18 ciclos de $95{ }^{\circ} \mathrm{C}$ por $30 \mathrm{~s}$ para desnaturação, $65{ }^{\circ} \mathrm{C}$ por $30 \mathrm{~s}$ para anelamento, e $68{ }^{\circ} \mathrm{C}$ por 6 min para extensão. No final, a reação foi mantida por mais 7 min a $68^{\circ} \mathrm{C}$.

\subsection{Transcrição in vitro do cDNA total amplificado}

A transcrição in vitro foi feita com a enzima T7 RNA polimerase, sendo realizada a adição do Cap 5' na porção inicial do mRNA (Figura 6).

Para reação de transcrição in vitro foram usados $1 \mu \mathrm{g}$ do produto de amplificação do cDNA total, ATP, CTP e UTP para uma concentração final de $0,4 \mathrm{mM}$, GTP para uma concentração final de $0,04 \mathrm{mM}, 2,5 \mu \mathrm{L}$ da estrutura análoga do Cap a $10 \mathrm{mM}$ (7mG(ppp)G RNA Cap Structure Analog, New England BioLabs, Ipswich, MA, EUA), DTT (Invitrogen) para uma concentração final de $5 \mathrm{mM}, 50$ unidades do Inibidor de RNAse (40 $\mathrm{U} / \mu \mathrm{L}$, New England BioLabs) e 30 unidades da enzima T7 RNA Polimerase (50 U/ $\mu \mathrm{L}$, Invitrogen) com seu tampão na concentração final $1 \mathrm{x}$, completando-se 0 volume da reação para $50 \mu \mathrm{L}$ com água tratada com DEPC. A reação foi incubada a uma temperatura de $37^{\circ} \mathrm{C}$ por $120 \mathrm{~min}$, adicionando-se, após 30 min de reação, $5 \mu \mathrm{L}$ de GTP a $10 \mathrm{mM}$ e, após 60 min de reação, $10 \mathrm{U}$ da enzima T7 RNA Polimerase. Por fim, foi feita uma incubação de 20 min a $-20^{\circ} \mathrm{C}$ para interromper a reação.

Uma modificação do protocolo foi feita, passando a se usar o mMESSAGE mMACHINE® T7 Transcription Kit (Invitrogen) para realizar a reação de transcrição. A reação foi feita adicionando-se a $200 \mathrm{ng}$ de produto da PCR, $10 \mu \mathrm{L}$ de NTP/CAP, $2 \mu \mathrm{L}$ de 10x Reaction Buffer, $2 \mu \mathrm{L}$ de Enzime mix, completando-se o volume para $20 \mu \mathrm{L}$ com água livre de nucleases. A reação foi mantida por 2 horas a $37^{\circ} \mathrm{C}$, sendo $1 \mu \mathrm{L}$ de GTP adicionado após os primeiros $30 \mathrm{~min}$. 
O RNA obtido pela reação com o kit foi purificado via precipitação com cloreto de lítio. Adicionou-se $20 \mu \mathrm{L}$ da solução de $\mathrm{LiCl}$ e $20 \mu \mathrm{L}$ de água a $10 \mu \mathrm{L}$ do produto da amplificação, incubando a mistura no freezer por $30 \mathrm{~min}$. Em seguida, o tubo foi centrifugado, sendo o pellet contendo o RNA lavado uma vez com $70 \%$ etanol e ressuspendido em água ultrapura.

Transcrição in vitro
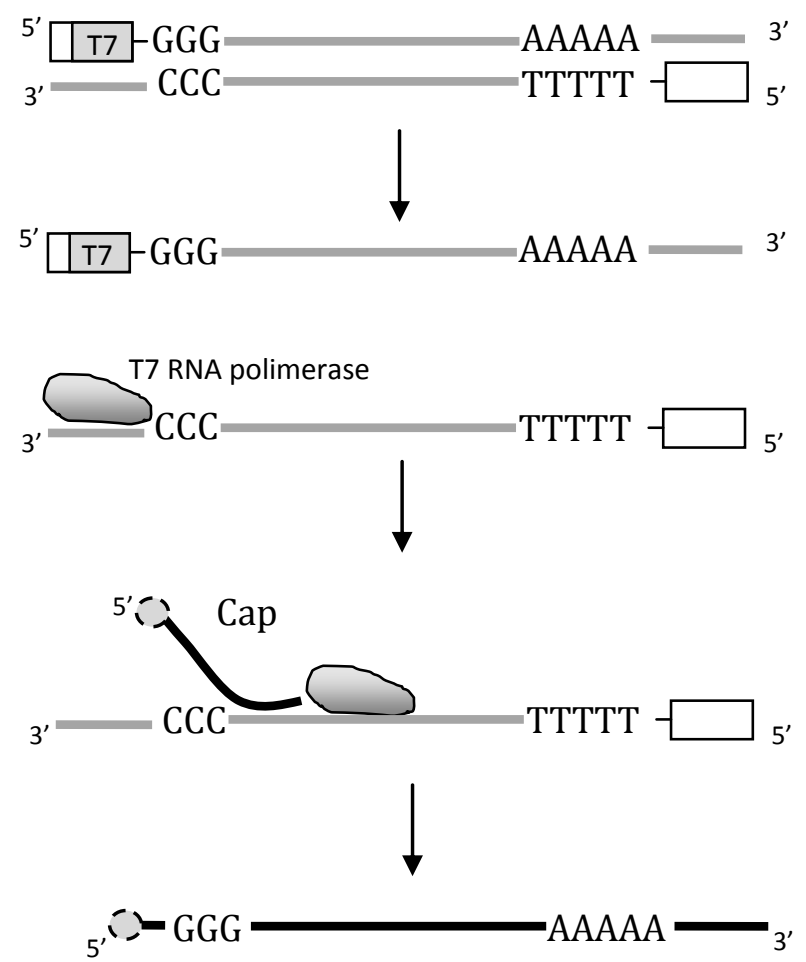

Figura 6 - Esquema do método de transcrição in vitro do cDNA. As duas fitas do cDNA são desnaturadas e a enzima T7 RNA polimerase transcreve o RNA usando como molde a fita $3^{\prime} \rightarrow 5^{\prime}$, gerando uma fita de mRNA com sequência idêntica à do mRNA original. Uma estrutura análoga ao Cap é adicionada na extremidade 5'do mRNA recém sintetizado.

\subsection{Tratamento com DNAse}

Para tratamento com DNAse, $1000 \mathrm{ng}$ de ácidos nucleicos foram adicionados a uma solução com volume final de $10 \mu \mathrm{L}$ contendo 1 unidade da enzima DNAse (Promega, Fitchburg, WI, EUA) e $1 \mu \mathrm{L}$ do seu tampão 10x. A reação foi mantida por 30 
min a $37^{\circ} \mathrm{C}$. Em seguida, adicionou-se $1 \mu \mathrm{L}$ de STOP Solution, incubando a amostra por mais 10 min a $65^{\circ} \mathrm{C}$ para interromper a reação.

\subsection{Recuperação de cDNA presente em gel de agarose}

Os cDNAs de interesse presentes em fragmentos de gel de agarose foram recuperados com o kit PureLink ${ }^{\circledR}$ Quick Gel Extraction Kit (Invitrogen) de acordo com as instruções do fabricante. Em suma, os fragmentos foram solubilizados a $50{ }^{\circ} \mathrm{C}$ com tampão de solubilização de gel, sendo o líquido obtido centrifugado sob uma coluna de extração de DNA, que posteriormente foi lavada e teve seu cDNA eluído com um tampão de eluição.

\subsection{Análise Estatística}

Para a análise estatística entre monócitos, iDCs e mDCs e entre células separadas, misturadas e fusão foi feito um teste Kolmogorov-Smirnov para testar se as amostras apresentavam distribuição normal (Gaussiana). Para amostras com distribuição normal, foi utilizado o teste de variância ANOVA com pós-teste de Bonferroni. Quando as amostras não apresentaram distribuição normal, foi utilizado o teste não paramétrico Kruskal-Walis com pós-teste Dunns. As diferenças foram consideradas estatisticamente significativas quando $o$ valor de $p$ for menor ou igual a $0,05\left({ }^{*} p \leq 0,05 ;{ }^{* *} p \leq 0,01\right.$; *** $p \leq 0,0001)$ nos resultados analisados. A análise estatística e os gráficos apresentados foram gerados com auxílio do software GraphPad Prisma versão 5 para Windows. 
4 RESULTADOS 


\subsection{Fenótipo celular durante a diferenciação de células dendríticas a partir de monócitos}

Para determinar se a diferenciação e maturação das células dendríticas ocorreram como esperado, células do dia 0 (monócitos), 5 (iDCs) e 7 (mDCs) de cultura (Figura 7) tiveram seu fenótipo de membrana analisado. Dois parâmetros foram analisados: a quantidade de células que expressavam cada marcador (porcentagem de células positivas) e a quantidade relativa de moléculas na superfície das células (intensidade relativa de fluorescência, RFI) (Figura 8).
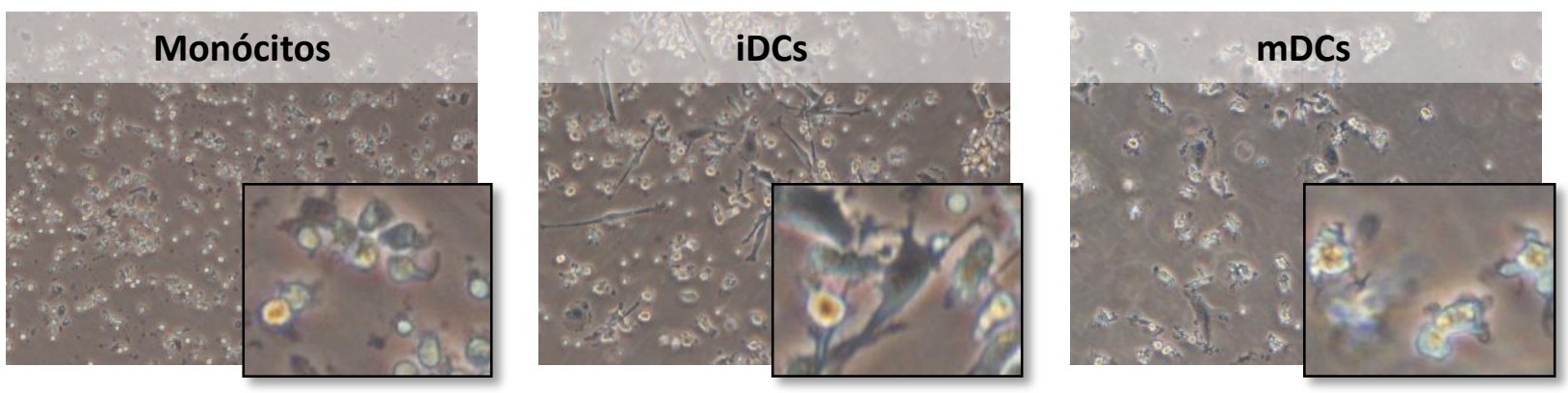

Figura 7 - Morfologia das células durante diferenciação de monócitos em

DCs. Fotos das células após 0 (monócitos), 5 (iDCs) ou 7 dias (mDCs) do inicio da cultura de diferenciação de monócitos em células dendríticas.

A quantidade de células positivas para CD14 caiu drasticamente durante a diferenciação, o que indica que o processo ocorreu como esperado, uma vez que CD14 é expresso em monócitos, mas apresenta baixa expressão em células dendríticas. As células obtidas mantém o fenótipo de APC profissional, dado que a expressão de HLA-DR foi mantida em todas as células durante a diferenciação. Porém, a quantidade de moléculas de HLA-ABC nas células diminuiu significativamente nas DCs. A expressão de CCR7 também teve um comportamento atípico, uma vez que não aumentou após a ativação, apresentando, ao contrário, uma tendência de queda.

Com relação às moléculas de co-estímulo CD80, CD86 e CD40, podemos observar um aumento em sua quantidade na superfície das mDCs quando comparada com as iDCs e os monócitos. A porcentagem de células positivas para CD86 foi alta durante toda a diferenciação, diminuindo no estado de iDC, mas, voltando a aumentar na 
mDC. Por outro lado, a quantidade de células expressando CD80 e CD40 aumentou gradativamente durante a cultura, sendo que, no último dia da cultura, quase a totalidade das células expressaram tais marcadores. A molécula CD274 (PD-L1) é uma molécula reguladora da resposta e também teve sua expressão aumentada, o que era esperado, uma vez que moléculas de regulação tendem a ter sua expressão aumentada quando a célula é ativada.

A ativação das iDCs com TNF- $\alpha$ teve o efeito esperado, uma vez que induziu um aumento da expressão de CD80, CD86 e CD40, além de aumentar significativamente a expressão do marcador de células dendríticas maduras, CD83.

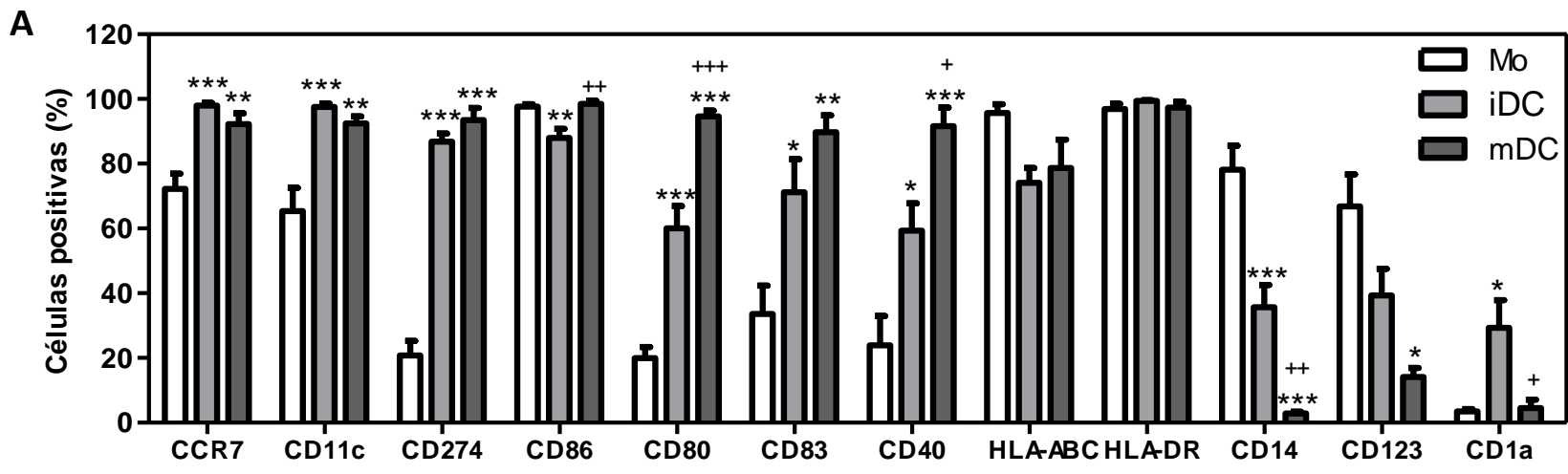

B

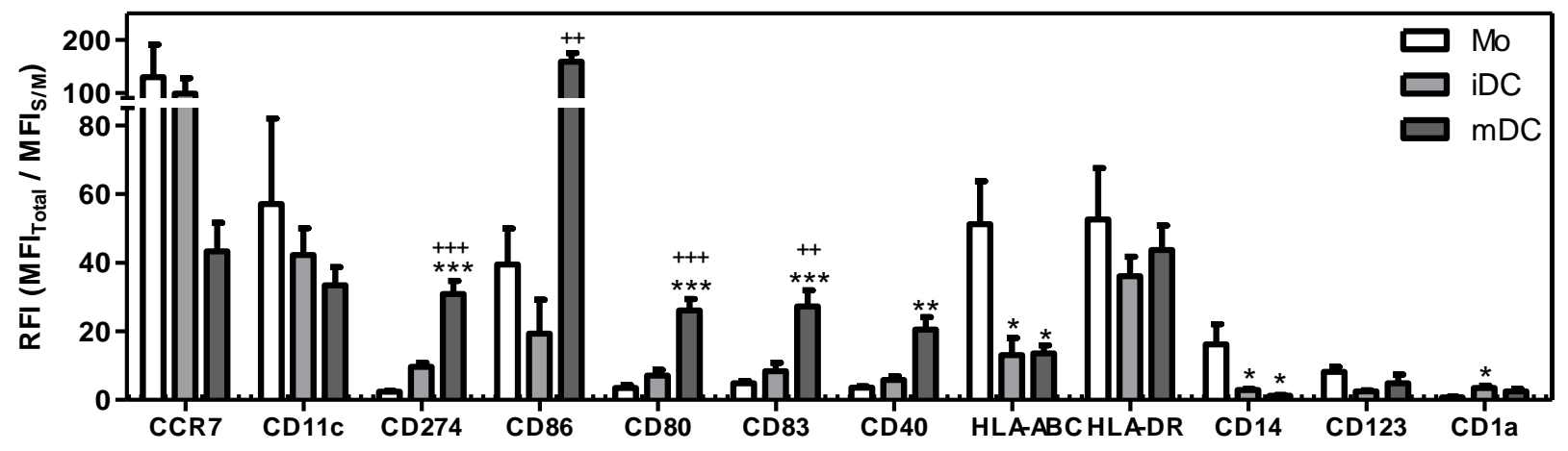

Figura 8 - Fenótipo celular durante a diferenciação de monócitos em mDCs. (A) Porcentagem de células positivas e $(B)$ intensidade relativa de fluorescência (RFI) de moléculas de superfície em monócitos, iDCs e mDCs $\left(n=5 ;{ }^{*} p<0,05,{ }^{* *} p<0,01,{ }^{* * *}\right.$ $p<0,001$ em relação ao monócito; $+p<0,05,++p<0,01,+++p<0,001$ em relação à iDC).

Portanto, de modo geral, as células dendríticas diferenciadas a partir de monócitos tiveram um fenótipo satisfatório e condizente com o esperado, expressando moléculas de apresentação de antígenos e de co-estimulação. 


\subsection{Fenótipo das linhagens de câncer de mama}
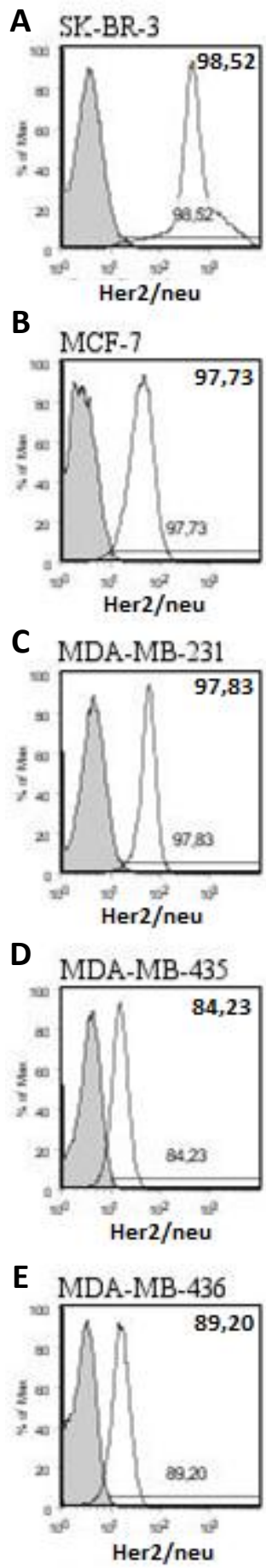
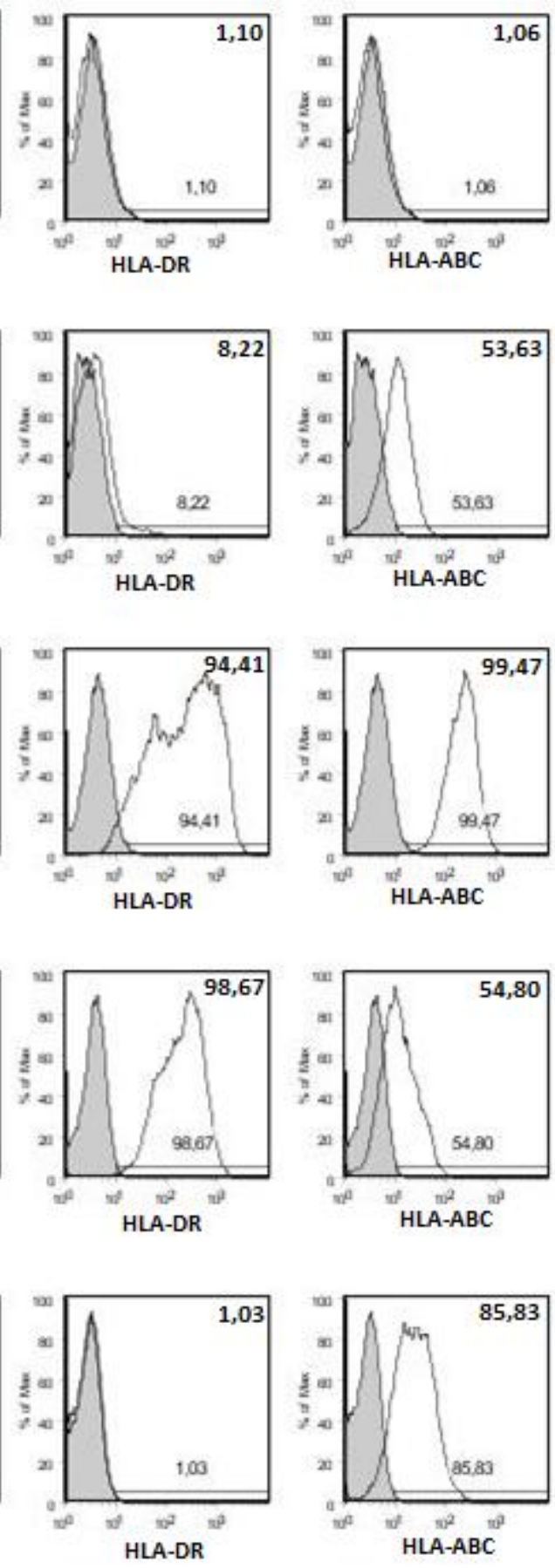
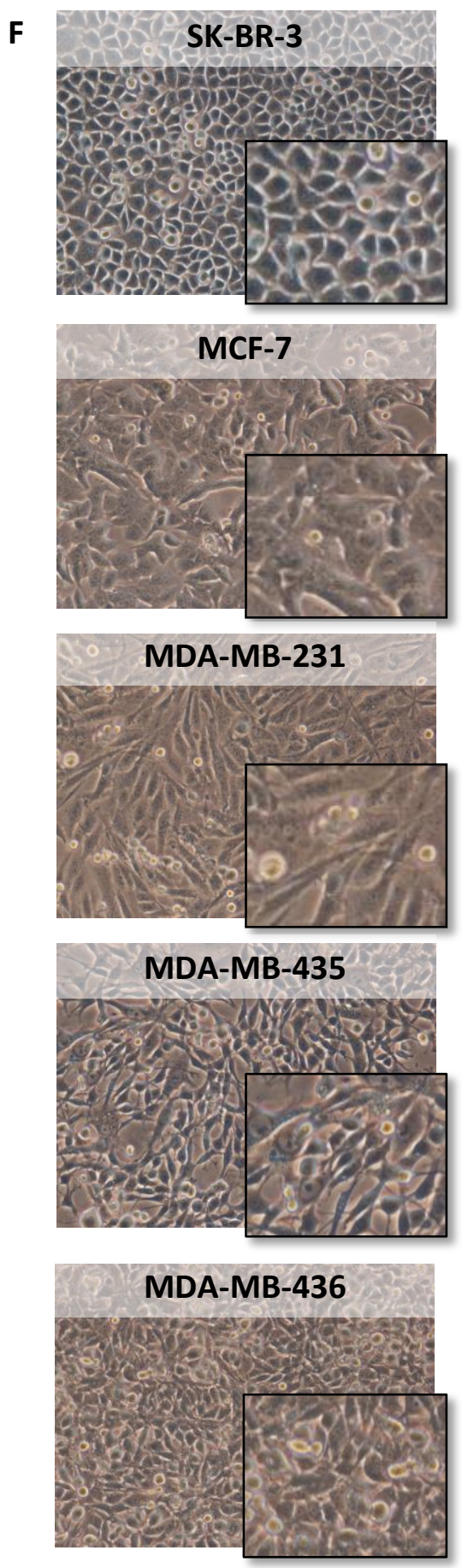

Figura 9 - Fenótipo das linhagens de câncer de mama. Avaliação da expressão de Her2/neu, HLA-DR e HLA-ABC por citometria de fluxo nas linhagens (A) SK-BR-3. (B) MCF-7. (C) MDA-MB-231. (D) MDA-MB-435. (E) MDA-MB-436. (F) Fotos de uma cultura confluente de cada uma das linhagens de câncer de mama. 
Dado que as células dendriticas foram diferenciadas corretamente, o próximo passo foi avaliar o fenótipo das linhagens celulares de câncer de mama a serem usadas no projeto. A expressão de Her2/neu, de uma das moléculas de classe II do MHC (HLA-DR) e das moléculas de classe I do MHC (HLA-ABC) foi avaliada nas linhagens por citometria de fluxo, desconsiderando-se os debris celulares e as células mortas (através do uso do Live/Dead) (Figura 9).

Observou-se a expressão de Her2/neu por mais de $80 \%$ das células de todas as linhagens, porém, a quantidade de moléculas de Her2/neu em cada célula da linhagem SK-BR-3 foi muito maior do que a observada nas outras linhagens.

Mais de $90 \%$ das células das linhagens SK-BR-3, MDA-MB-436 e MCF-7 não apresentaram expressão de HLA-DR. Foi detectada a expressão heterogênea de HLA-DR nas células das linhagens MDA-MB-231 e MDA-MB-435, com algumas células apresentando expressão elevada e outras expressão baixa.

A única linhagem que não apresentou expressão de HLA-ABC foi a SK-BR-3, o que a tornaria "invisível" aos linfócitos $\mathrm{T} \mathrm{CD}^{+} \mathrm{e}$, portanto, possivelmente resistente à morte induzida pelos linfócitos T CD8 ${ }^{+}$citotóxicos.

Escolheu-se então, como células doadoras de mRNA, as células da linhagem SK-BR-3, uma vez que essa foi a única linhagem que apresentou superexpressão de Her2/neu. Assim, seria esperado que a transferência do mRNA dessas células para qualquer uma das células das outras linhagens gerasse um aumento de Her2/neu na linhagem receptora do mRNA. Desse modo, a eficiência da transfecção poderia ser detectada através desse marcador de superfície. Como célula receptora do mRNA foi escolhida a linhagem MDA-MB-231, por ser, de todas as linhagens disponíveis, a mais potencialmente imunogênica, ou seja, a que mais expressa moléculas de classe I do MHC.

\subsection{Análise da porcentagem de híbridos após eletroporação}

Em seguida, avaliou-se a formação de heterocarions entre as células dendríticas diferenciadas de monócitos e as células de linhagens tumorais. A porcentagem de híbridos foi avaliada em duas condições de fusão diferentes (ver 3.6) através da 
porcentagem de células positivas para os corantes Violet e Green, que foram usados para corar previamente cada um dos tipos celulares. O segundo protocolo se mostrou mais eficiente, sendo o usado nos próximos experimentos (Figura 10). Intrigantemente, o grupo contendo a mistura das células dos dois tipos celulares sem, porém, terem sido eletroporadas (MIX) gerou uma quantidade elevada de células duplo-positivas.
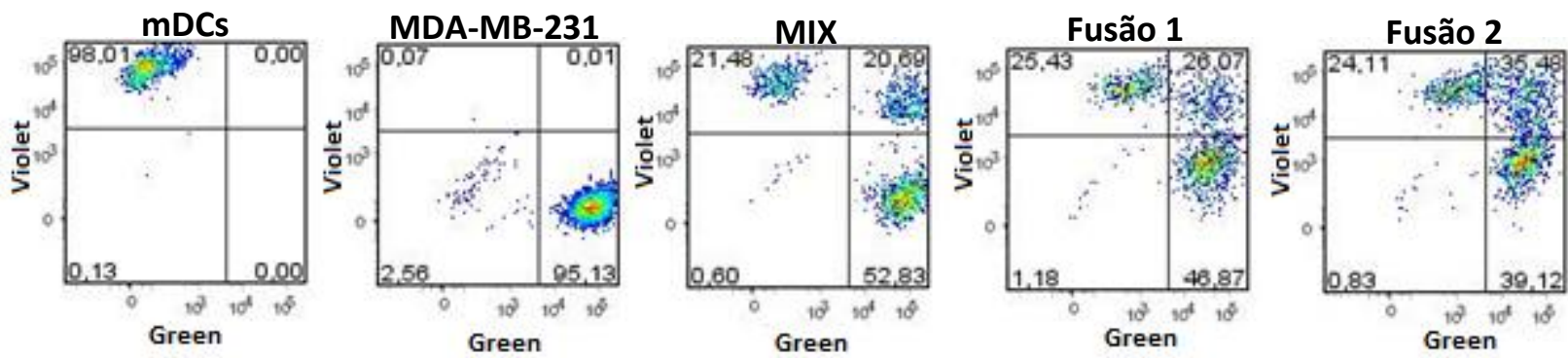

Figura 10 - Marcação dos corantes Green e Violet após dois processos distintos de fusão. Gráfico de pontos mostrando a expressão de Green e Violet em células da linhagem MDA-MB-231 e mDCs separadas, misturadas (MIX), ou fundidas por dois métodos diferentes de eletroporação (Fusão 1 e Fusão 2).

A

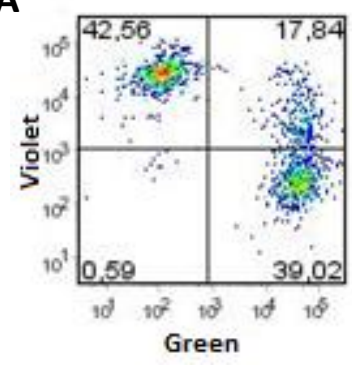

B

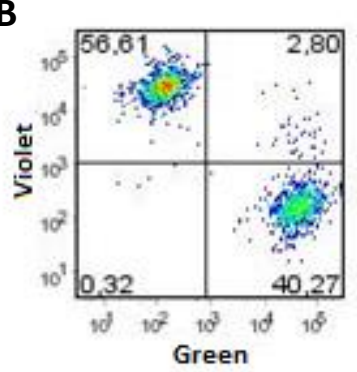

C

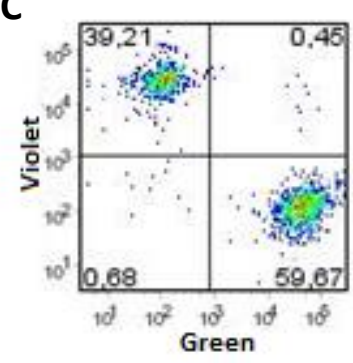

D

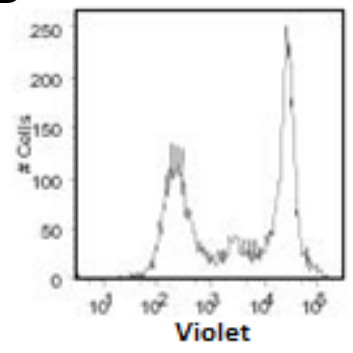

E

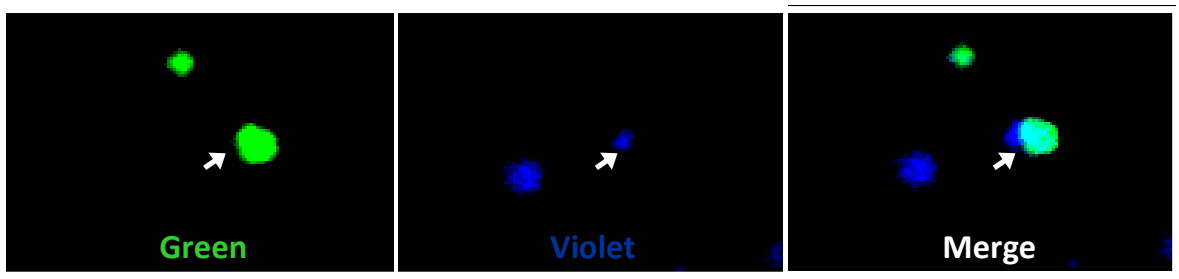

Figura 11 - Análise da dupla-positividade na mistura de mDCs e MDA-MB-231.

Gráfico de pontos mostrando a marcação dos corantes Violet e Green em mDCs e MDA-

MB-231 que (A) ficaram interagindo por $1 \mathrm{~h}$ antes de serem fixadas, (B) que foram fixadas imediatamente após serem misturadas ou (C) foram fixadas antes de serem

misturadas. (D) Histograma da intensidade de fluorescência do Violet em células misturadas e fixadas após $1 \mathrm{~h}$. (E) Fotos de microscopia de fluorescência de mDCs e MDA-MB-231 que foram misturadas fixadas após $1 \mathrm{~h}$. 
Para avaliar o motivo da grande quantidade de células duplo-positivas no MIX, foi feito um experimento onde mDCs e células da linhagem MDA-MB-231 interagiram por diferentes tempos, sendo, em seguida, fixadas e lidas no citômetro de fluxo para avaliação da porcentagem de células duplo-positivas. Foi possível observar que, quanto maior o tempo de interação, maior era a quantidade de células duplo-positivas (Figura 11A-C). Além disso, as células duplo-positivas apresentaram uma intensidade de fluorescência no violeta intermediária entre as células marcadas com esse corante (mDCs) e não marcadas (MDA-MB-231) (Figura 11D). Foi possível observar também, por microscopia de fluorescência, algumas células verdes (MDA-MB-231) que apresentavam uma pequena região marcada com violeta (Figura 11E). Esses dois dados corroboram a hipótese de que as células tumorais, ao serem misturadas com mDCs, de alguma forma incorporam parte da coloração das mDCs, processo que poderia ocorrer, por exemplo, através da incorporação de exossomos de mDCs pelas células tumorais. O processo de eletroporação, a partir de então, começou a ser feito a $4{ }^{\circ} \mathrm{C}$, visando minimizar a interação das células enquanto essas estivessem sendo fundidas, permitindo assim uma leitura mais confiável da quantidade de células híbridas obtidas.

A
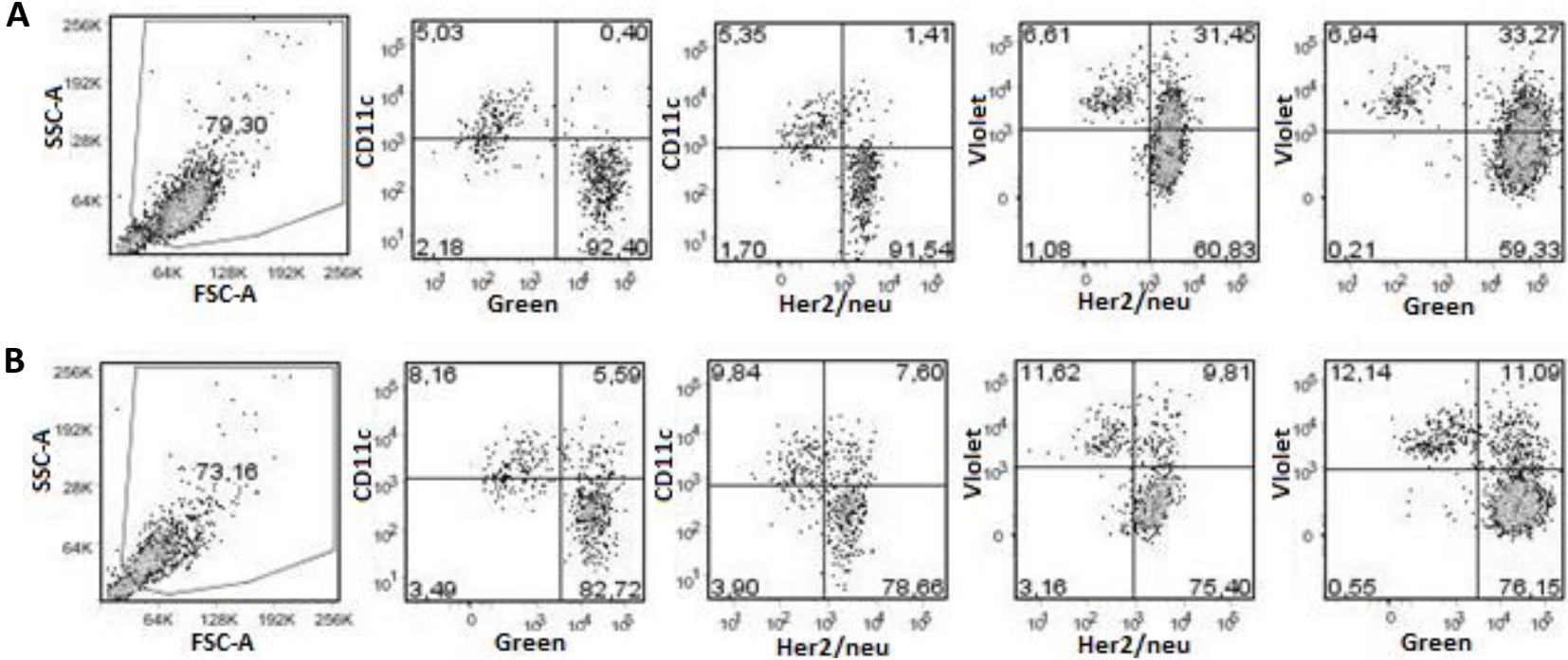

Figura 12 - Análise da porcentagem de híbridos utilizando diferentes combinações de corantes e marcadores de membrana. Análise das células da linhagem MDA-MB231 e mDCs (A) misturadas ou (B) fundidas. Porcentagem de células duplo-positivas obtidas analisando-se a marcação de dois corantes celulares (Violet $x$ Green), um corante e um marcador de membrana (CD11c $x$ Green / Violet $x$ Her2) ou dois marcadores de membrana (CD11c $x$ Her2). 
Em seguida, a quantidade de células fundidas foi avaliada por dois diferentes métodos (corantes e marcadores de membranas) visando descobrir qual era mais confiável para determinar a eficiência da fusão. Ao contrário da marcação com corantes, foram encontradas poucas células duplo-positivas na mistura quando foram analisados os marcadores de membrana (Figura 12). Sendo assim, optou-se por fazer a determinação da quantidade de híbridos utilizando-se os marcadores de membrana.
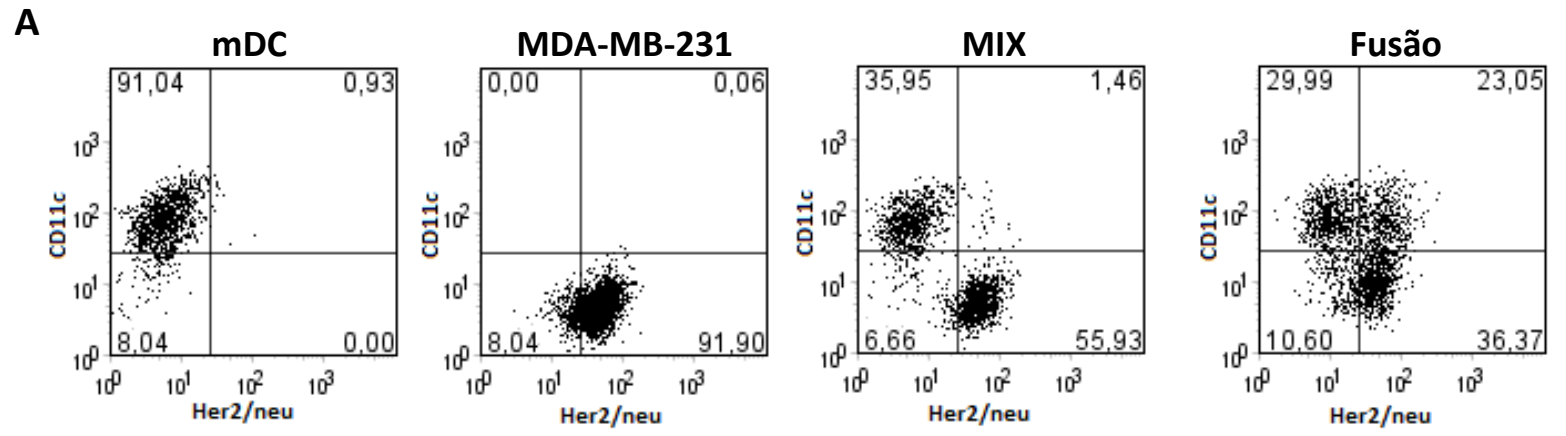

B

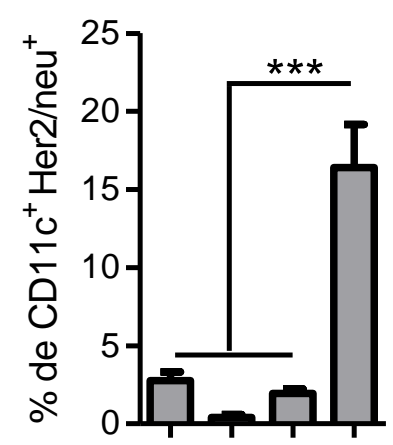

C

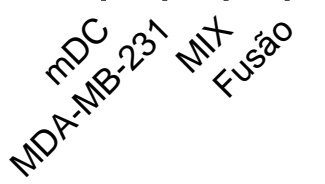

Figura 13 - Análise da eficiência da fusão. (A) Porcentagem de células positivas para CD11c e Her2/neu $\left(n=14 ;{ }^{* \star *} p<0,001\right)$. (B) Fotos de células encontradas no grupo de células eletroporadas.

Foi possível observar que o método de eletroporação aumentou a porcentagem de células duplo-positivas (Figura 13; Mix: $1.9 \pm 0.3$; Fusão: $16.4 \pm 2.8 ; p<0.0001 ; n=14$ ). Também foi possível observar células com dois nucléolos (e às vezes até com dois núcleos distintos) no grupo de células que foram eletroporadas. Por microscopia de fluorescência e confocal, observou-se que as células duplo-positivas presentes no grupo de células eletroporadas apresentavam, em sua maioria, dois nucléolos (Figura 14). 


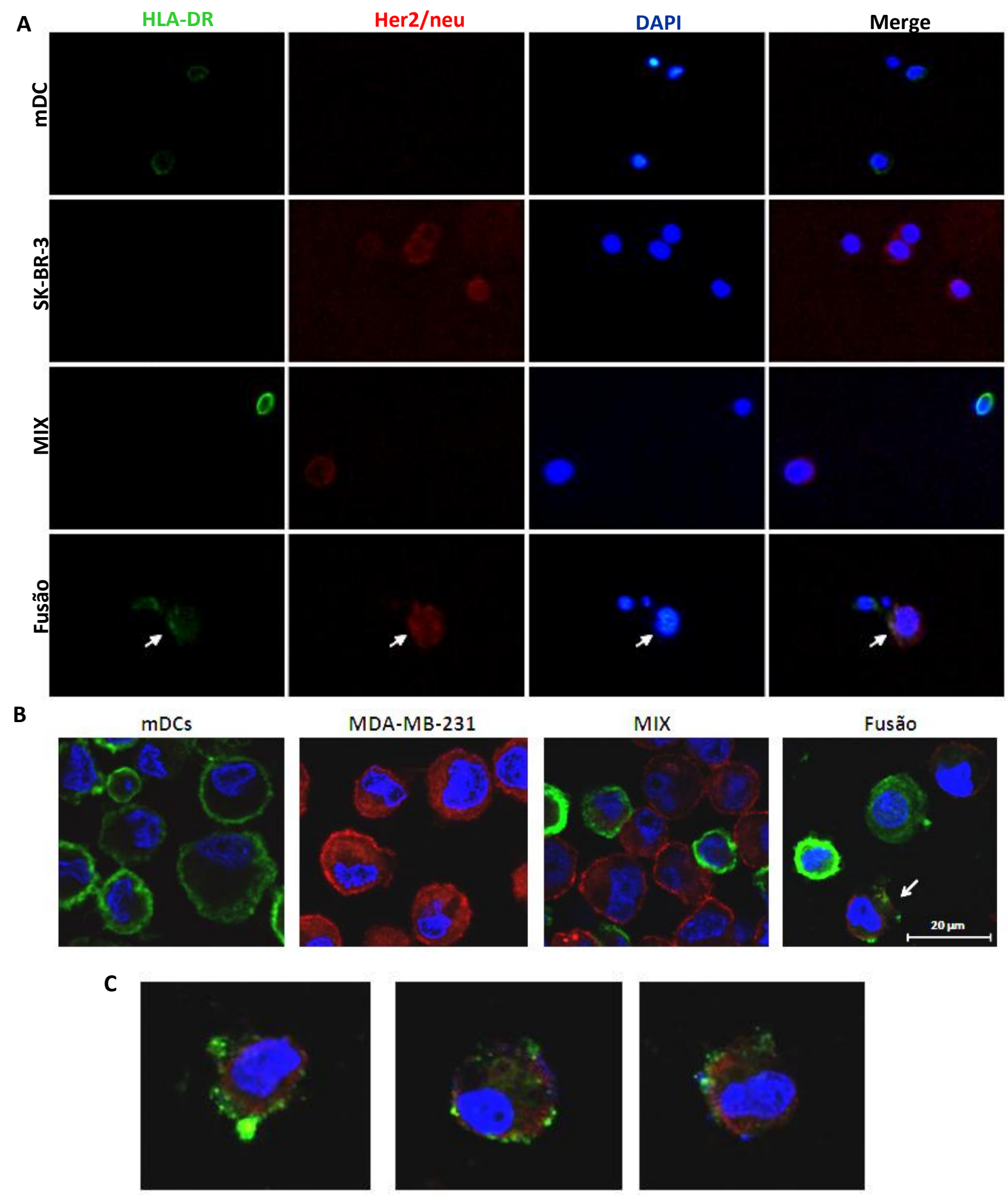

Figura 14 - Microscopia das células fundidas. Fotos obtidas por (A) microscopia de fluorescência e (B) microscopia confocal de células marcadas com anticorpos para moléculas de superfície e o marcador de núcleo DAPI. (C) Células duplo-positivas presentes no grupo Fusão. 


\subsection{Híbridos de DCs maduras e imaturas}

Dois experimentos independentes foram feitos comparando-se a fusão de células tumorais com iDCs e com mDCs. A porcentagem de células duplo-positivas para CD11C e Her2/neu foi avaliada após a eletroporação de cada um dos grupos, revelando uma maior quantidade de células híbridas nos grupos eletroporados com mDCs (Figura 15).
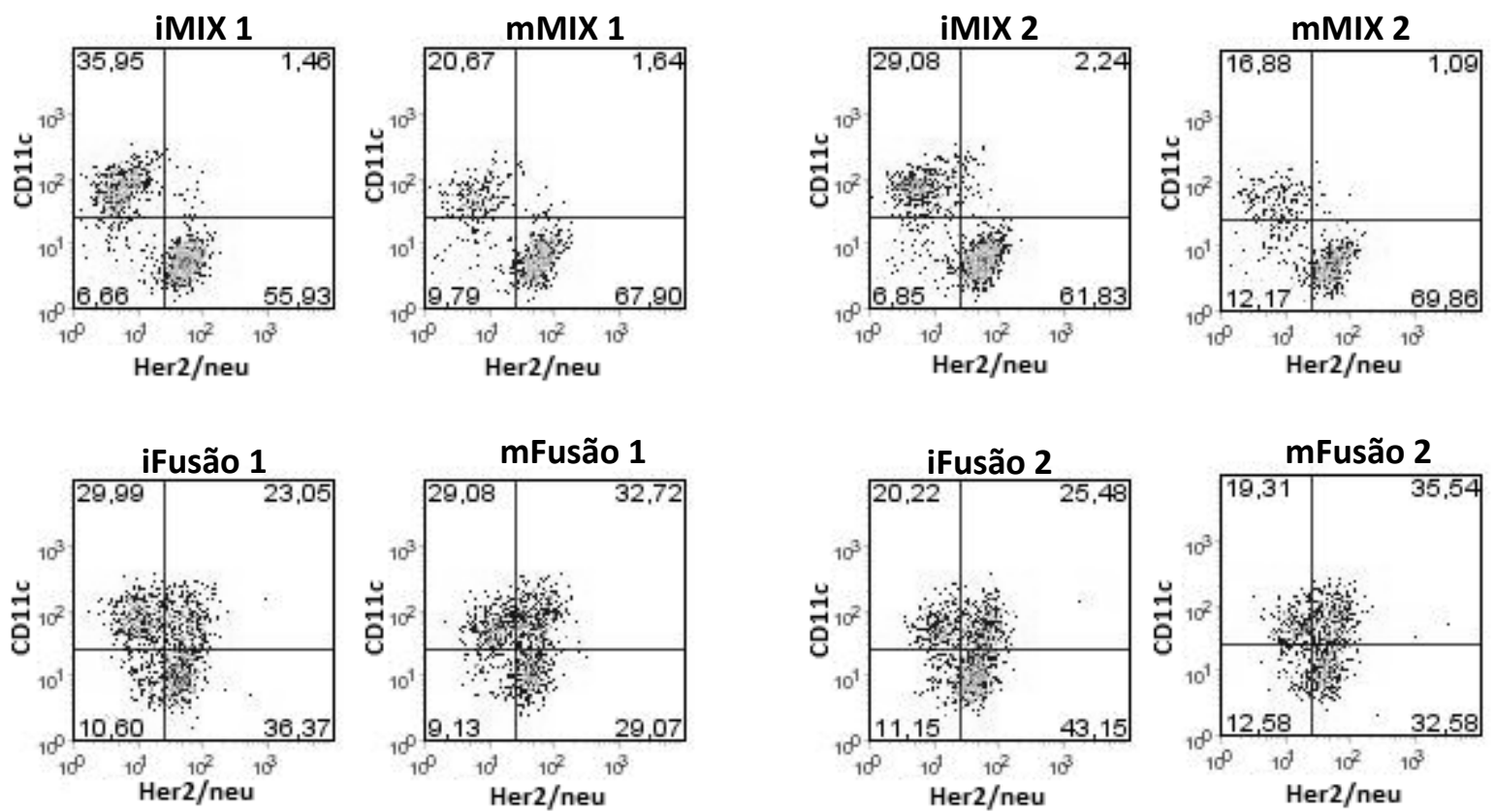

Figura 15 - Porcentagem de híbridos de células tumorais com iDCs ou mDCs. Porcentagem de células duplo-positivas para CD11c e Her2/neu na mistura de células tumorais da linhagem MDA-MB-231 com iDCs (iMIX) ou mDCs (mMIX) e na fusão de células tumorais e iDCs (iFusão) ou mDCs (mFusão) em dois experimentos independentes.

Além da porcentagem de células positivas, avaliou-se também a intensidade de expressão de HLA-DR em cada um dos tipos celulares presentes na mistura de células tumorais com DCs imaturas (iMIX) e DCs maduras (mMIX), além da fusão obtida usando iDCs (iFusão) e mDCs (mFusão) (Figura 16). 


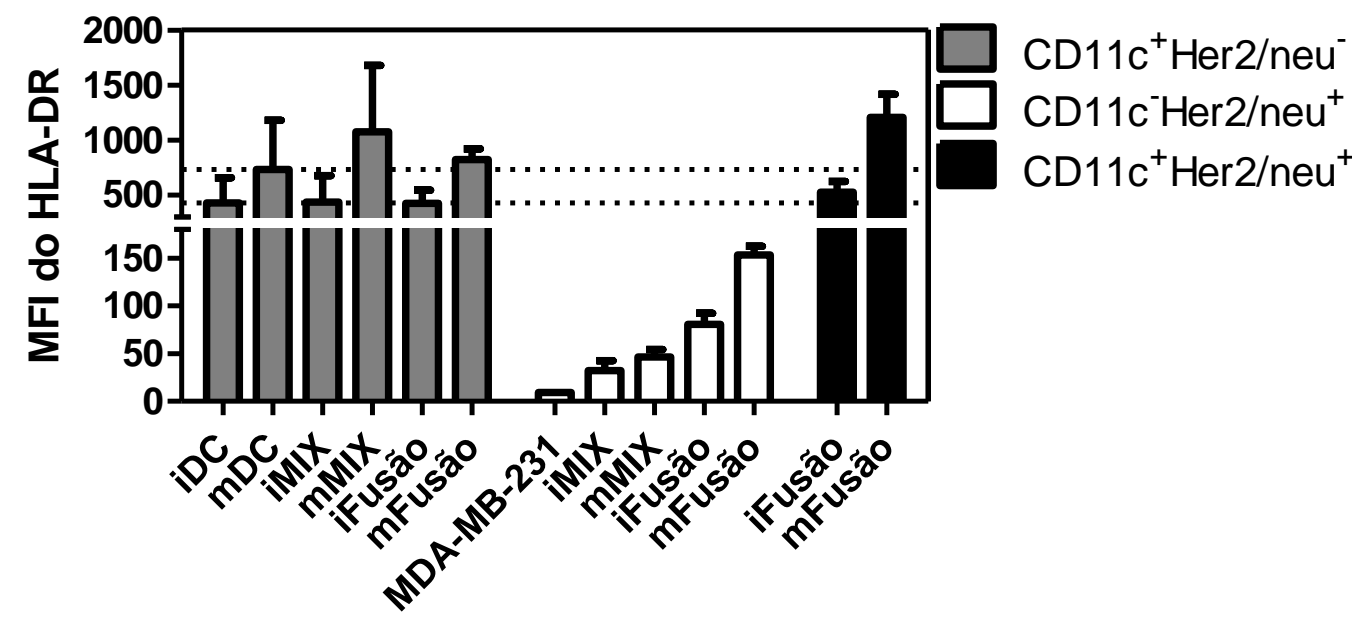

Figura 16 - Quantidade de HLA-DR em cada tipo celular após processo de eletroporação. Intensidade mediana de fluorescência do HLA-DR em células

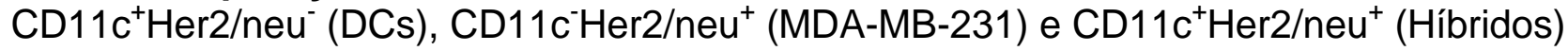
após a mistura de células tumorais e iDCs (iMIX) ou mDCs (mMIX) ou eletroporação das MDA-MB-231 com iDCs (iFusão) ou mDCs (mFusão) ( $n=2)$.

Como esperado, as mDCs apresentaram maior MFI do que as iDCs, não havendo diferença se estas haviam sido misturadas com células tumorais ou até mesmo eletroporadas. As células tumorais sozinhas apresentaram baixa expressão de HLA-DR, sendo essa aumentada se essas células haviam sido misturadas com células dendríticas maduras ou imaturas. Porém, a maior expressão de HLA-DR nas células tumorais foi encontrada no grupo dessas células que sofreu eletroporação com mDCs. Avaliando a expressão nos híbridos, foi possível observar a mesma intensidade de HLA-DR nos híbridos de iDCs e nas iDCs sozinhas, enquanto os híbridos de mDCs apresentaram intensidade de HLA-DR ainda maior do que as mDCs sozinhas. Esses dados mostram que as células presentes no grupo de células tumorais eletroporadas com mDCs expressam maior HLA-DR quando comparadas com a eletroporação com iDCs, tornando essas células melhores apresentadoras de antígenos.

Sendo assim, os híbridos passaram a ser formados apenas por células dendríticas maduras (mDCs). O próximo passo foi, então, avaliar o fenótipo de membrana dos híbridos gerados com essas células. 


\subsection{Fenótipo de membrana dos híbridos}

O nível de expressão de diversos marcadores de células dendríticas foi avaliado nas células que sofreram o processo de fusão (Figura 17). As células misturadas e eletroporadas (Fusão), independente de apresentaram um fenótipo Her2 ${ }^{+}$CD11C $^{+}$, expressaram níveis equivalentes à $\mathrm{mDC}$ de CD80, CD40 e CD83. Por outro lado, apenas as células misturadas e eletroporadas que tinham o fenótipo Her2 ${ }^{+} \mathrm{CD}_{11 \mathrm{c}^{+}}\left(\mathrm{Fusão}^{+/+}\right.$) apresentaram a mesma porcentagem de células positivas para HLA-DR e CD86 encontrada no grupo das mDCs.
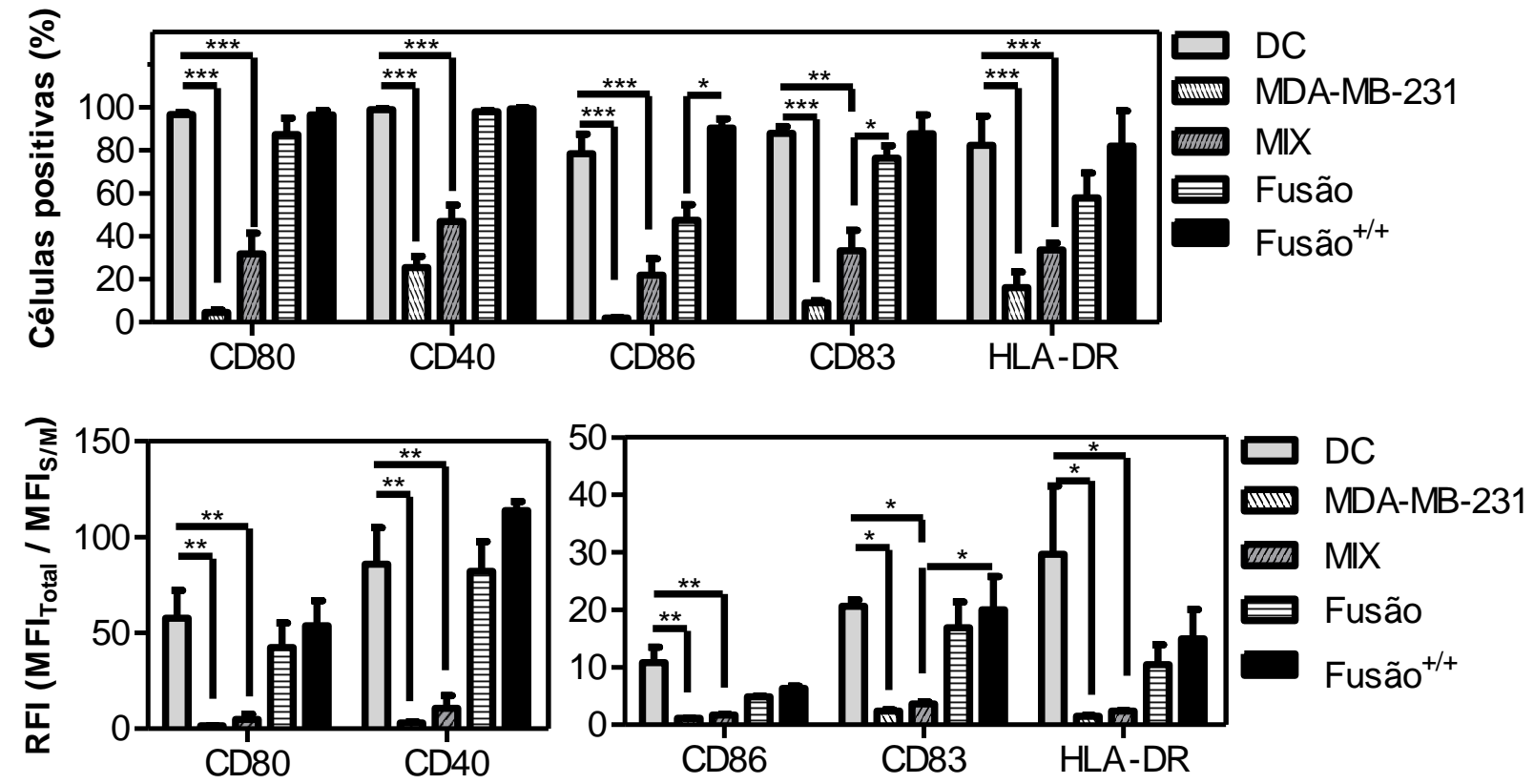

Figura 17 - Fenótipo das células que sofreram o processo da fusão. (A) porcentagem de células positivas e (B) intensidade relativa de fluorescência (RFI) de

moléculas de superfície em DCs, MDA-MB-231, células misturadas (MIX), células eletroporadas (Fusão) ou apenas as células eletroporadas que apresentam um fenótipo Her2 $^{+}$CD11 $^{+}\left(\right.$Fusão $\left.^{+/+}\right)\left(C D 80\right.$ e CD40: $n=4$; CD86, CD83, HLA-DR: $n=3 ;{ }^{*} p<0,05,{ }^{*}$ *

$$
\left.p<0,01,{ }^{* * *} p<0,001\right) \text {. }
$$

A expressão de moléculas de HLA-ABC na superfície das células fundidas mostrou-se significativamente maior do que no grupo de células misturadas e no grupo das mDCs (Figura 18A). Para verificar se esse aumento de expressão era devido a uma 
co-expressão de moléculas de HLA-ABC provenientes das células tumorais e das mDCs, cada uma dessas células foram coradas, antes da eletroporação, com um anticorpo para HLA-ABC com um fluorocromo diferente. O procedimento foi feito todo no gelo visando minimizar ao máximo a dissociação do anticorpo e seu ligante. No grupo eletroporado, foi possível observar $11,93 \%$ de células positivas na fusão, contra apenas 2,95\% no MIX (Figura 18B). Outro experimento mostrou que, dentre as células que eram CD11 ${ }^{+}$ Her2/neu+, 74,32\% expressavam HLA-ABC proveniente das duas células, o que mostra que as células fundidas expressam moléculas de classe I do MHC provenientes de ambas as células (Figura 18C).

A

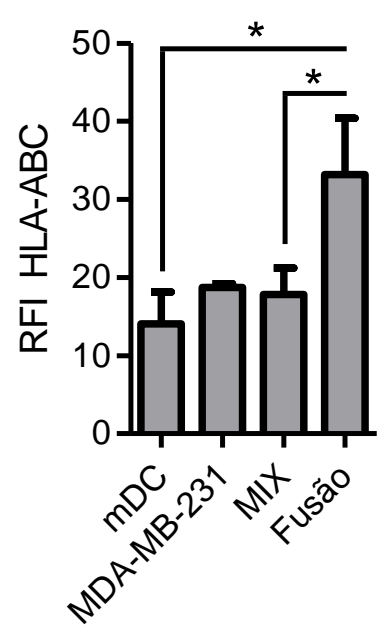

B

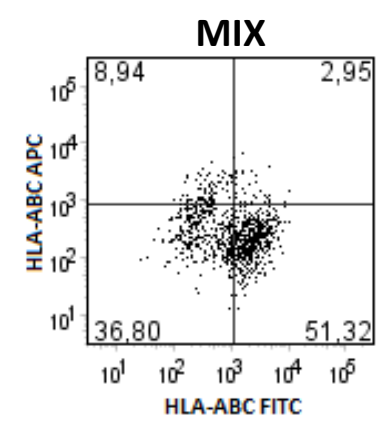

C

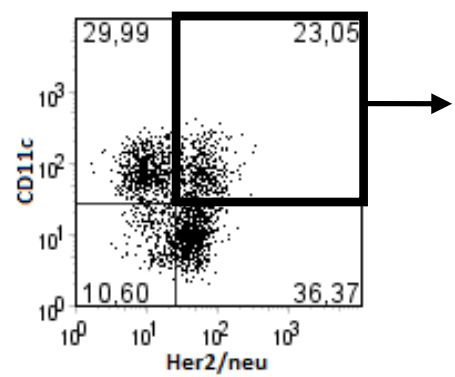

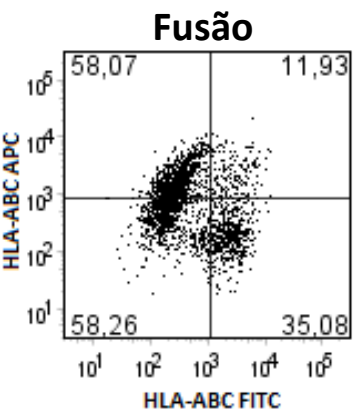

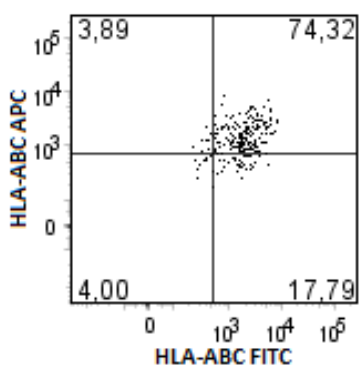

Figura 18 - Expressão de HLA-ABC nas células fundidas. (A) Intensidade mediana de fluorescência (MFI) de HLA-ABC em células da linhagem MDA-MB-231, mDCs, uma mistura dessas células (MIX) e células fundidas. (B) Células tumorais foram marcadas com HLA-ABC FITC enquanto mDCs foram marcadas com HLA-ABC APC, sendo, em seguidas, misturadas (MIX) e eletroporadas (Fusão). (C) Análise da expressão das duas moléculas de HLA-ABC dentro das células duplo-positivas para CD11c e Her2/neu no grupo fusão. 


\subsection{Efeito da irradiação nas células}

Durante um ensaio de co-cultura, a irradiação das células estimuladoras é necessária para parar a sua proliferação, principalmente no caso de estímulo com células tumorais, para que essas não consumam todo o meio. Além disso, a irradiação é importante para parar a proliferação dos híbridos a serem utilizados para imunoterapia. Porém, é necessário avaliar se as células irradiadas realmente pararam de proliferar e se há alguma alteração relevante em seu fenótipo.

As células MDA-MB-231 parecem ter parado de crescer após irradiação com 200 Gy, uma vez que, enquanto as que não foram irradiadas entraram em confluência após 7 dias, as que foram irradiadas continuaram em uma pequena quantidade. Porém, não foi possível avaliar a proliferação pela diluição de CFSE, uma vez que as células não apresentaram um pico uniforme de marcação logo após serem coradas (dados não mostrados).

As células KA2 (K562 expressando HLA-A2) a serem usadas nos ensaios de microcultura também parecem ter parado de proliferar, uma vez, que após 10 dias da irradiação com 40 Gy, o meio das células não havia sido consumido e, ao olhar sob o microscópio, a quantidade de células no grupo irradiado era muito inferior ao encontrado no grupo controle, sem irradiação (Figure 19).
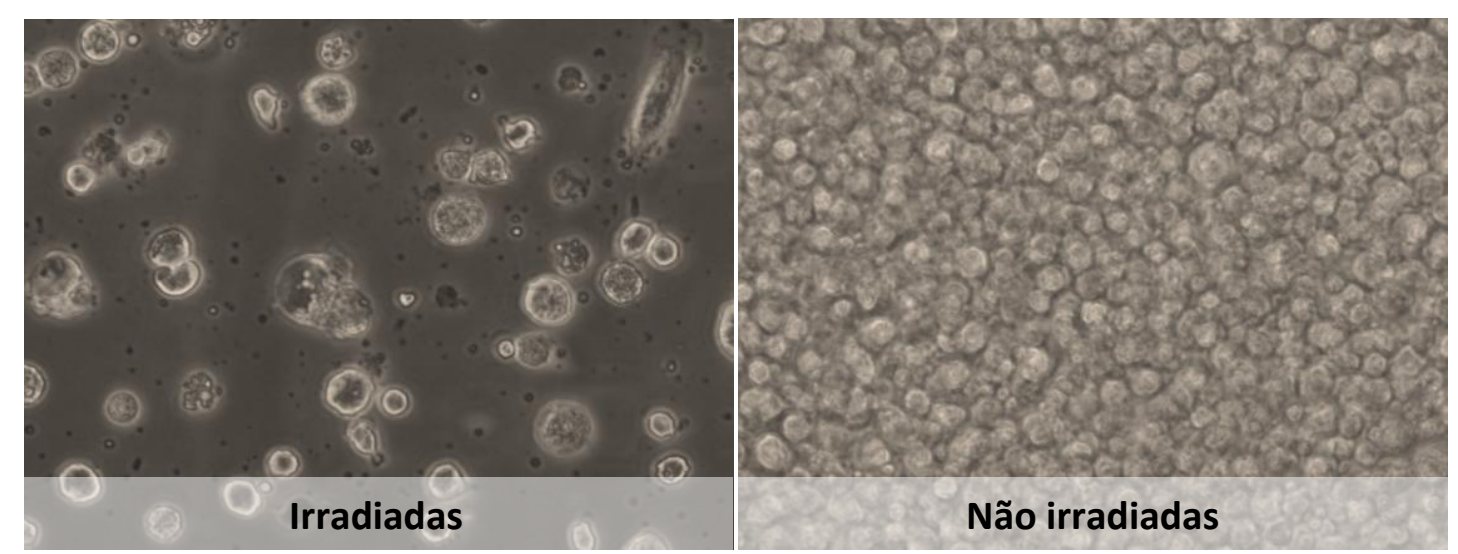

Figure 19 - Efeito da irradiação no crescimento de células KA2. Foto da cultura de células KA2 10 dias após as células terem sido irradiadas com 40 Gy (esquerda) ou mantidas sem irradiação (direita). 
Não foi possível observar diferenças nos marcadores de membrana CD80, CD40, CCR7, HLA-ABC e HLA-DR logo após a irradiação (dados não mostrados). A porcentagem de células duplo-positivas no grupo da fusão, porém, diminuiu ligeiramente no grupo que foi irradiado em três experimentos independentes (Figura 20).
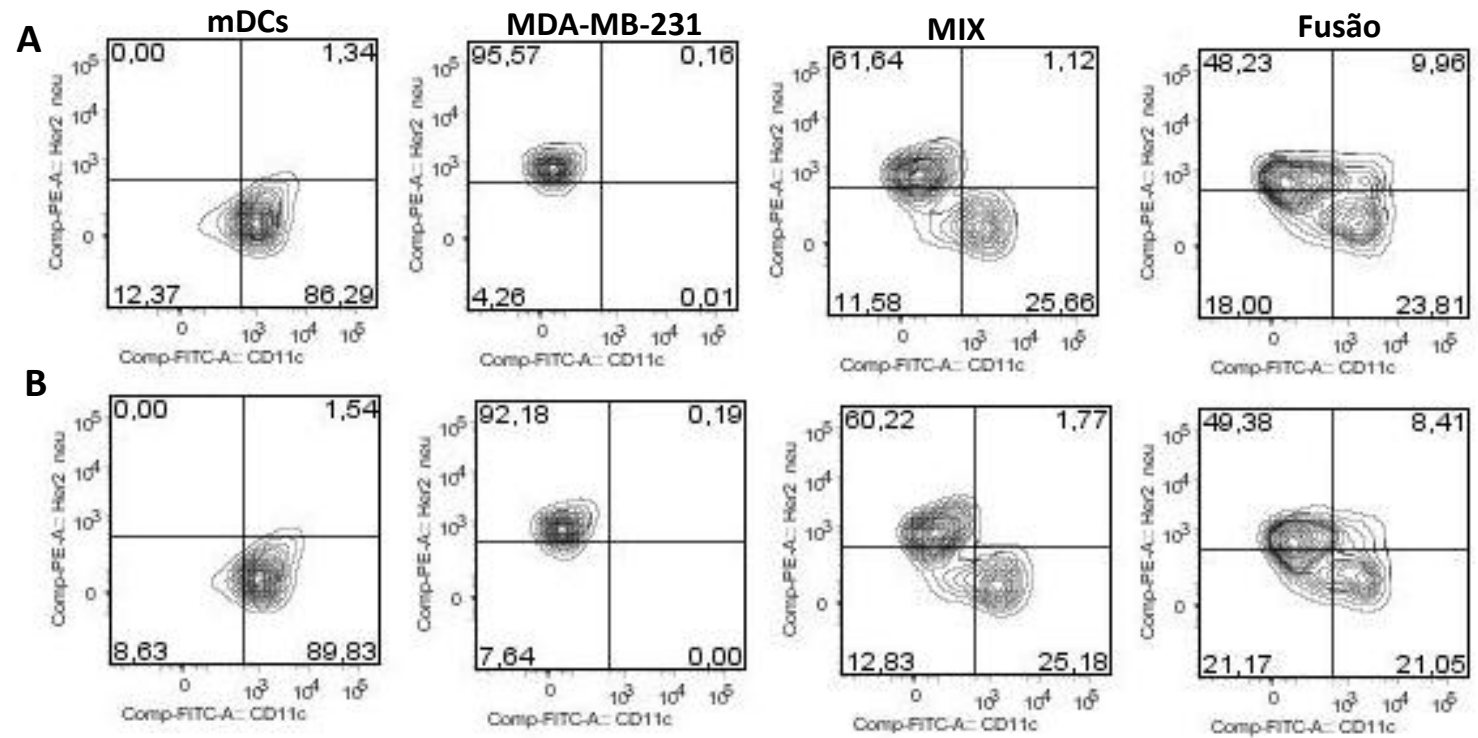

Figura 20 - Análise da expressão de CD11c e Her2/neu em células irradiadas. Gráfico representativo da expressão de CD11c por Her2/neu em mDCs, MDA-MB-231, a mistura dessas duas células e em híbridos que foram ou não irradiados. (A) Células não irradiadas. (B) Células irradiadas

De modo geral a irradiação funcionou conforme esperado, seguindo-se assim para os experimentos de linfoestimulação com as células híbridas.

\subsection{Capacidade dos híbridos em induzir linfoproliferação}

Primeiramente, experimentos foram feitos visando analisar se os híbridos seriam capazes de estimular a proliferação de linfócitos T. Analisou-se, em três experimentos independentes, a proliferação de linfócitos $\mathrm{T} \mathrm{CD}^{+}{ }^{+}$e $\mathrm{CD} 8^{+}$estimulados, por 5 dias, com mDCs, MDA-MB-231, as duas células misturadas (MIX) ou fundidas (Fusão). Linfócitos T autólogos ou alogeneicos às mDCs de cada ensaio foram utilizados, avaliando-se a 
porcentagem de linfócitos T com diluição de CFSE, que corresponde à porcentagem de células provenientes de linfócitos T que sofreram proliferação (Figura 21).
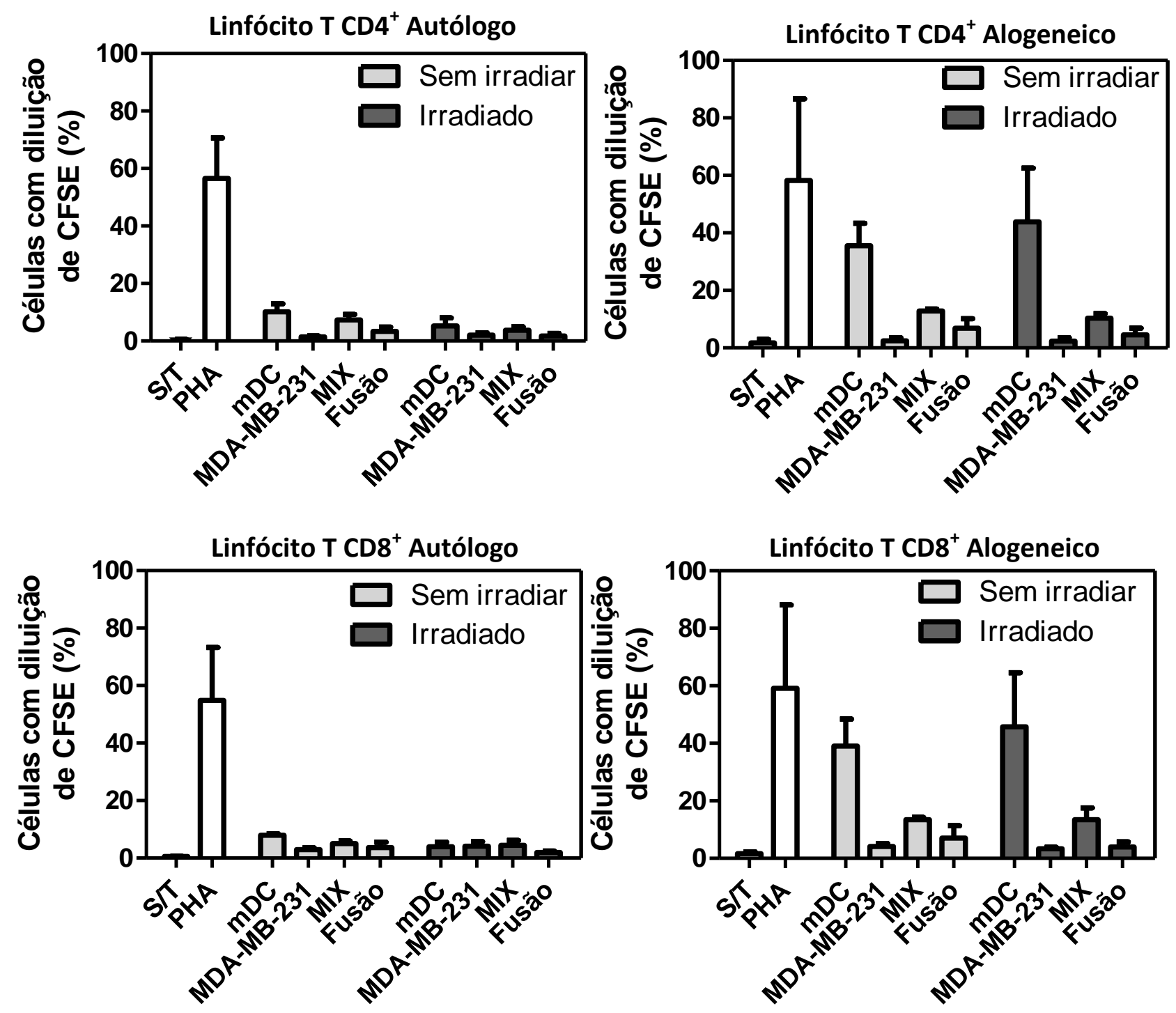

Figura 21 - Proliferação de linfócitos T induzida pela fusão. Linfócitos T autólogos ou alogeneicos às DCs usadas em cada experimento foram estimulados com mDCs, MDAMB-231, uma mistura (MIX) ou fusão dessas células. As células estimuladoras foram ou não previamente irradiadas com 200 Gy. A fitohemaglutinina (PHA) foi utilizada como controle positivo de proliferação. Células sem tratamento $(\mathrm{S} / \mathrm{T})$ foram consideradas como controle negativo. A porcentagem de linfócitos T CD4 ${ }^{+}$ou $\mathrm{CD} 8^{+}$com diluição de CFSE foi avaliada após 5 dias de estimulação $(n=3)$.

Foi possível detectar proliferação de linfócitos T autólogos, mas sem diferenças significativas entre os grupos. Também não houve diferença estatisticamente significativa 
entre os linfócitos T alogeneicos estimulados com o MIX ou a fusão. Não foi possível observar alteração significativa na capacidade de linfoestimulação das células irradiadas em comparação com as não irradiadas, apesar de ter sido observado uma diminuição da proliferação induzida pelas células irradiadas em dois dos três experimentos. Um perfil semelhante de ativação foi encontrado analisando-se a porcentagem de células positivas para CD25 (dados não mostrados).

A análise do sobrenadante das culturas autólogas por CBA não revelou quantidades significativas das citocinas IL-4 e TNF- $\alpha$ e IL-17A. IL-10 só foi detectada no grupo MIX sem irradiar, mas próximo ao limiar mínimo de detecção do método (dados não mostrados). Pequenas concentrações de IL-2, também próximas ao limiar mínimo do método, foram detectadas nas células tratadas com os diferentes estímulos, porém, sem diferenças entre os grupos (Figura 22). Uma concentração muito elevada de IL-6 foi encontrada nos grupos onde as células tumorais da linhagem MDA-MB-231 foram utilizadas, sendo essa concentração menor no grupo de células híbridas. IFN-y foi detectado nos grupos de linfócitos T que foram tratados com o MIX ou com a fusão, mas sem diferença estatística entre os grupos.
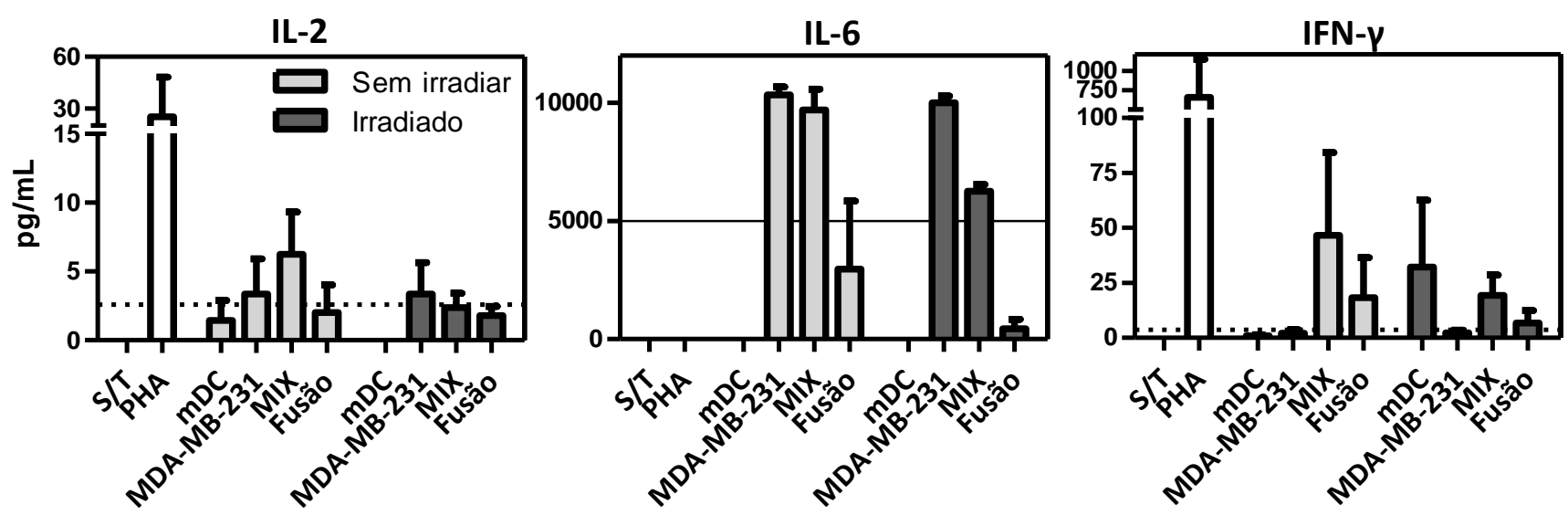

Figura 22 - Produção de citocinas no sobrenadante do ensaio de proliferação de linfócitos T estimulados com a fusão. Análise da presença das citocinas IL-2, IL-6 e IFN-y por CBA no sobrenadante da co-cultura de cinco dias entre linfócitos T autólogos e mDCs, MDA-MB-231, uma mistura (MIX) ou fusão dessas células irradiadas ou não com 200 Gy. A fitohemaglutinina (PHA) foi utilizada como controle positivo de proliferação.

Células sem tratamento $(\mathrm{S} / \mathrm{T})$ foram consideradas o controle negativo. As linhas pontilhadas e contínuas indicam o limite inferior e superior de detecção da reação, respectivamente $(n=3)$. 


\subsection{Resposta imune induzida pelos híbridos}

Dado que os híbridos foram capazes de estimular a proliferação de linfócitos $T$, o próximo passo consistiu em analisar o tipo de resposta que esses linfócitos eram capazes de gerar. Portanto, foi feito um experimento de sensibilização em macrocultura, onde linfócitos $T$ autólogos foram estimulados duas vezes com mDCs e MDA-MB-231 misturadas ou fundidas, e irradiadas com 200 Gy na presença de IL-2 e IL-7. No decorrer da sensibilização, foi possível observar blastos e grumos de células nas culturas com os dois estímulos. Após 2 dias da segunda estimulação, foi possível observar linfócitos $T$ interagindo com células grandes, que provavelmente são as células estimuladoras utilizadas (Figura 23). Essas células maiores não foram mais encontradas no final do segundo estímulo, sendo possível observar restos celulares antes das trocas de meio.

A

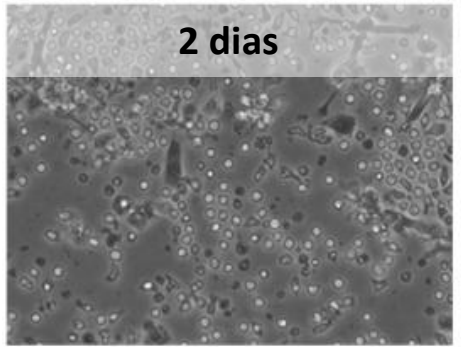

\section{5 dias}
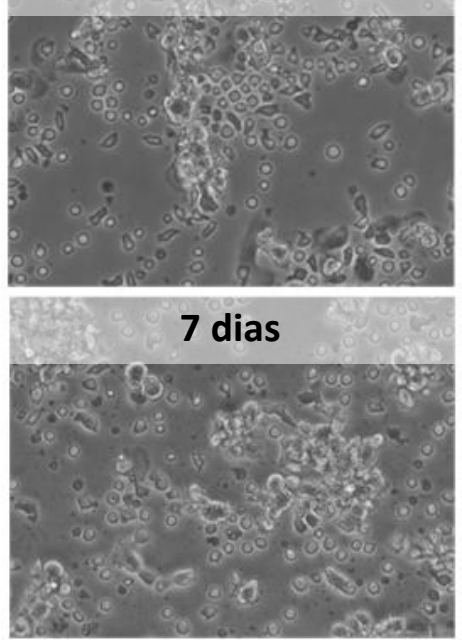

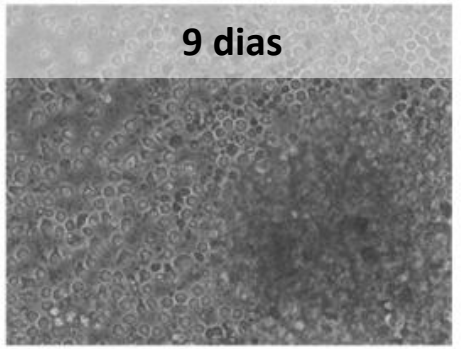

12 dias

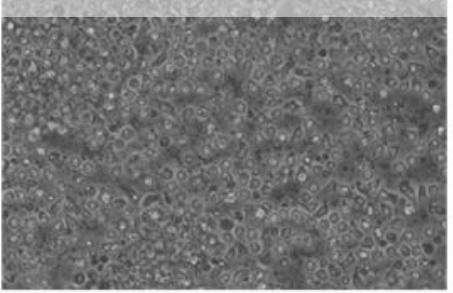

14 dias
B

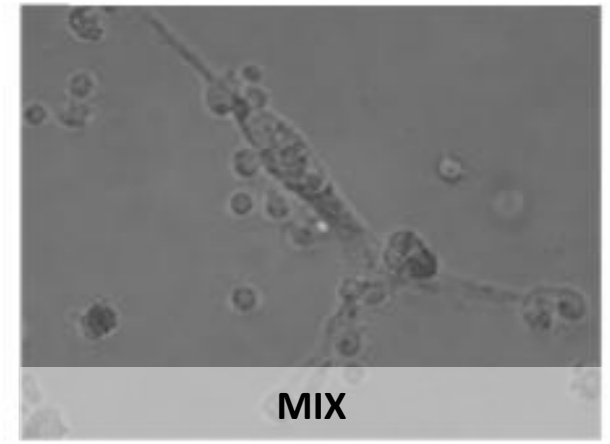

Fusão

Figura 23 - Fotos da sensibilização de linfócitos T com a fusão. (A) Fotos de linfócitos T estimulados pela fusão depois de passados diferentes dias do estímulo inicial. (B) Fotos das culturas de linfócitos T após dois dias do segundo estímulo (Dia 9) com a mistura (MIX) ou fusão de mDCs com células da linhagem MDA-MB-231. 
O fenótipo dos linfócitos $\mathrm{T} \mathrm{CD4^{+ }}$ e $\mathrm{CD} 8^{+}$foi avaliado após 7 e 14 dias do início do protocolo de sensibilização (Tabela 4). A porcentagem de células positivas para CD25 se manteve elevada nos dois tipos de linfócitos $T$ durante o experimento. Já a expressão de CD62L foi reduzida após a segunda estimulação, indicando a perda de uma molécula presente em linfócitos T naïve por, pelo menos, 10\% das células. Também foi possível observar o aparecimento de células positivas para CD45RO após a segunda estimulação, demonstrando o aparecimento de linfócitos $T$ de memória após o protocolo de sensibilização.

Tabela 4 - Fenótipo dos linfócitos T sensibilizados pela fusão. Porcentagem de linfócitos $\mathrm{T} \mathrm{CD}^{+}$ou $\mathrm{CD}^{+}$positivos para as moléculas de interesse após sete dias (após primeira sensibilização) ou 14 dias (após segunda sensibilização) do início do protocolo de sensibilização em macrocultura. Os linfócitos T foram mantidos sem células estimuladoras $(\mathrm{S} / \mathrm{T})$ ou estimulados com células mDCs misturadas (MIX) ou fundidas com células da linhagem MDA-MB-231,

\begin{tabular}{|c|c|c|c|c|c|c|}
\hline \multicolumn{7}{|c|}{ CD4 } \\
\hline \multirow[t]{2}{*}{ Molécula } & \multicolumn{3}{|c|}{ Primeira sensibilização } & \multicolumn{3}{|c|}{ Segunda sensibilização } \\
\hline & $\mathbf{S} / \mathbf{T}$ & MIX & Fusão & $\mathbf{S} / \mathbf{T}$ & MIX & Fusão \\
\hline CD25 & 92.68 & 89.30 & 91.62 & 90.62 & 85.80 & 89.01 \\
\hline CD62L & 99.82 & 99.09 & 99.71 & 81.22 & 83.96 & 83.65 \\
\hline CD45RA & 23.12 & 30.42 & 30.12 & 41.32 & 53.25 & 35.57 \\
\hline CD45RO & 0.08 & 0.02 & 0.08 & 46.00 & 39.68 & 47.67 \\
\hline PD-1 & 86.41 & 83.41 & 88.33 & 67.14 & 60.27 & 63.99 \\
\hline CD38 & 81.44 & 88.89 & 87.60 & 88.11 & 90.41 & 87.72 \\
\hline \multicolumn{7}{|c|}{ CD8 } \\
\hline \multirow[t]{2}{*}{ Molécula } & \multicolumn{3}{|c|}{ Primeira sensibilização } & \multicolumn{3}{|c|}{ Segunda sensibilização } \\
\hline & $\mathbf{S} / \mathbf{T}$ & MIX & Fusão & $\mathbf{S} / \mathbf{T}$ & MIX & Fusão \\
\hline CD25 & 60.97 & 67.51 & 69.16 & 75.30 & 62.11 & 69.90 \\
\hline CD62L & 96.45 & 94.51 & 94.17 & 75.91 & 81.62 & 78.71 \\
\hline CD45RA & 54.19 & 52.40 & 57.68 & 60.51 & 68.91 & 55.64 \\
\hline CD45RO & 2.01 & 1.63 & 2.82 & 28.33 & 26.85 & 34.51 \\
\hline PD-1 & 82.11 & 81.02 & 82.79 & 49.45 & 48.60 & 48.39 \\
\hline CD38 & 71.43 & 88.37 & 83.62 & 83.88 & 83.01 & 81.16 \\
\hline
\end{tabular}


Por outro lado, observou-se, tanto em linfócitos $\mathrm{T} \mathrm{CD4}^{+}$quanto nos linfócitos $\mathrm{T}$ $\mathrm{CD}^{+}$, a diminuição da molécula PD-1, que regula negativamente a ativação de linfócitos T, após a segunda estimulação. Não foi possível observar grandes alterações na expressão de CD38, que se manteve elevada durante toda a cultura. Com relação à molécula CD69, observou-se um pico de positividade nos linfócitos $T$ sem tratamento apenas após a primeira semana, enquanto que os linfócitos T estimulados com MIX ou fusão apresentaram esse pico apenas após a segunda estimulação (Figura 24).
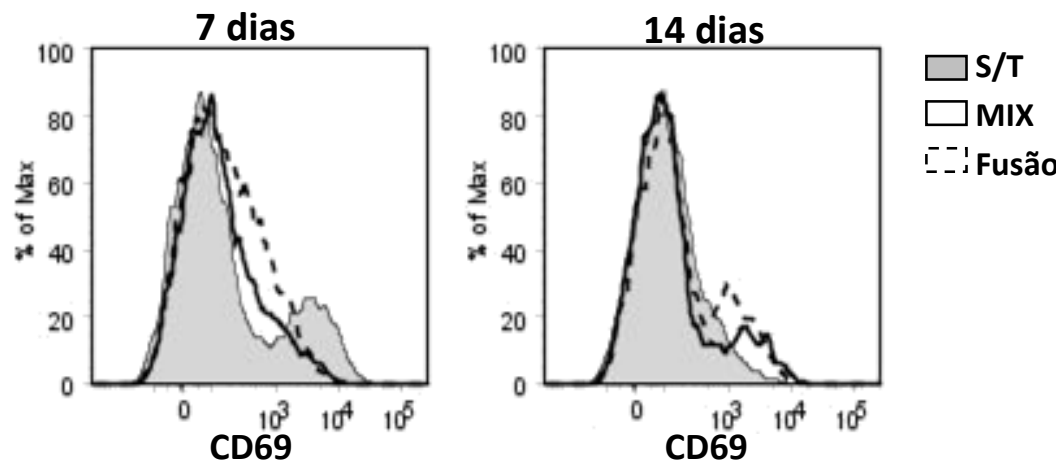

Figura 24 - Expressão de CD69 após uma ou duas semanas do início do ensaio de sensibilização. Histograma da expressão de CD69 em linfócitos T CD4 após a primeira (7 dias) ou a segunda estimulação (14 dias) com MIX ou fusão.

Durante a sensibilização, o meio das células foi constantemente trocado, impedindo a análise da produção de citocinas por CBA. Para analisar as citocinas produzidas pelos linfócitos $T$ sensibilizados, após a primeira semana de estimulação, uma parte dos linfócitos $T$ foram colocados em placas de 96 poços e mantidos por 5 dias, sem troca de meio ou adição de IL-2 ou IL-7. Os linfócitos T foram mantidos sem tratamento ou na presença de fitohemaglutinina (PHA) ou reestimulados com a mesma célula estimuladora utilizada na primeira semana (MIX para as células previamente estimuladas com MIX ou Fusão para as células previamente estimuladas com Fusão) (Figura 25). De modo geral, os linfócitos T mantiveram a capacidade de produção de citocinas frente a um estímulo inespecífico, porém, as células previamente tratadas com MIX ou fusão produziram menos IL-10 e mais IL-4 ao serem estimuladas com fitohemaglutinina do que o grupo que não havia sido tratado previamente com células $(\mathrm{S} / \mathrm{T})$. Foi possível detectar a presença de IFN-y e TNF- $\alpha$ no sobrenadante das culturas de linfócitos T reestimulados com MIX ou fusão. Porém, IL-6 foi observado apenas no 
grupo de linfócitos T reestimulados com o MIX. A citocina IL-17A não foi detectada em nenhum grupo.
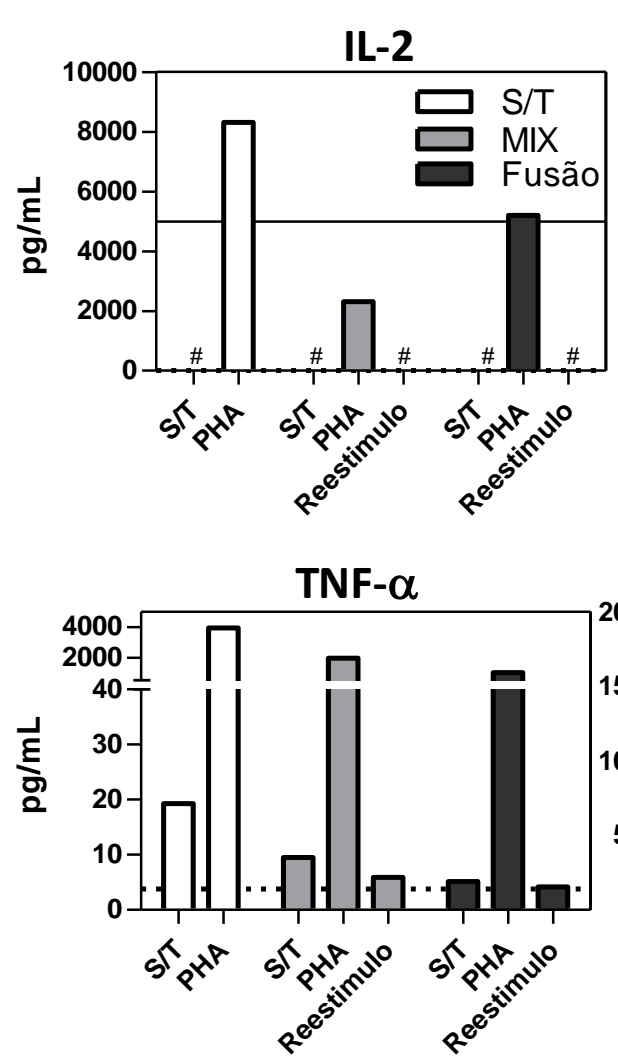
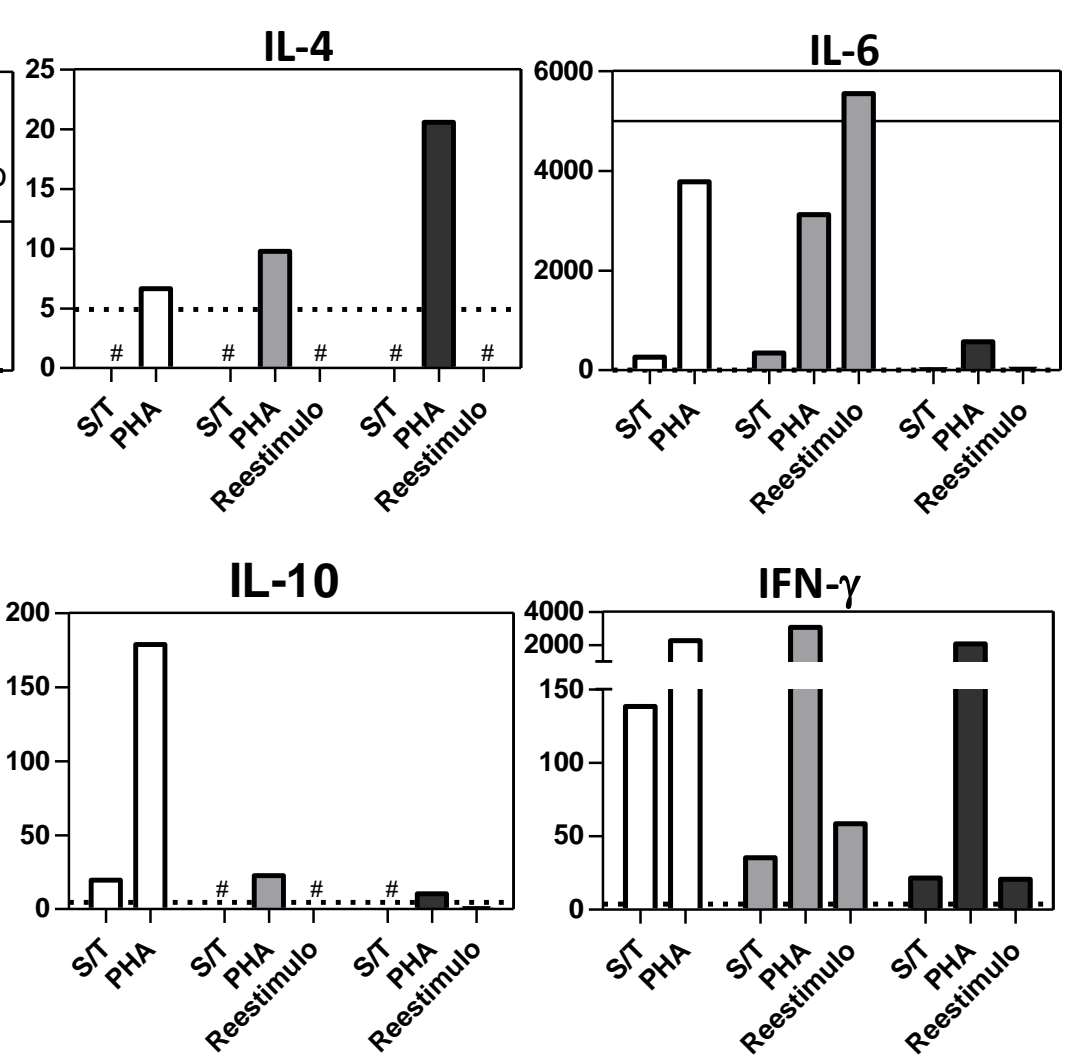

Figura 25 - Citocinas no sobrenadante do ensaio de sensibilização de linfócitos $T$ estimulados com a fusão. Linfócitos T previamente tratados com MIX (cinza) ou Fusão (preto) ou mantidos sem tratamento (branco) por sete dias foram plaqueados em placa de 96 poços. Esses linfócitos foram mantidos por 5 dias sem estímulo (S/T), estimulados com PHA, ou reestimulados com as células que haviam sido usadas na primeira semana

de estímulo. O sobrenadante dessas culturas foi analisado quanto à presença de citocinas por CBA. As linhas pontilhadas e contínuas indicam o limite inferior e superior de detecção da reação, respectivamente (\# não detectado).

Em seguida, avaliou-se a polarização dos linfócitos T CD4 que foram sensibilizados com o MIX ou a fusão (Figura 26). De modo geral, não houve mudanças drásticas no padrão de células T helper entre os três grupos, sendo o fator de transcrição RORyt presente na maior porcentagem dos linfócitos de todos os grupos. Por outro lado, a porcentagem de células positivas para o fator de transcrição Foxp3 foi maior no grupo de linfócitos T que foram sensibilizados com o MIX, e menor no grupo de linfócitos $T$ que foram 
sensibilizados com a fusão. A expressão de Foxp3 nos linfócitos T cultivados apenas com citocinas foi intermediária.
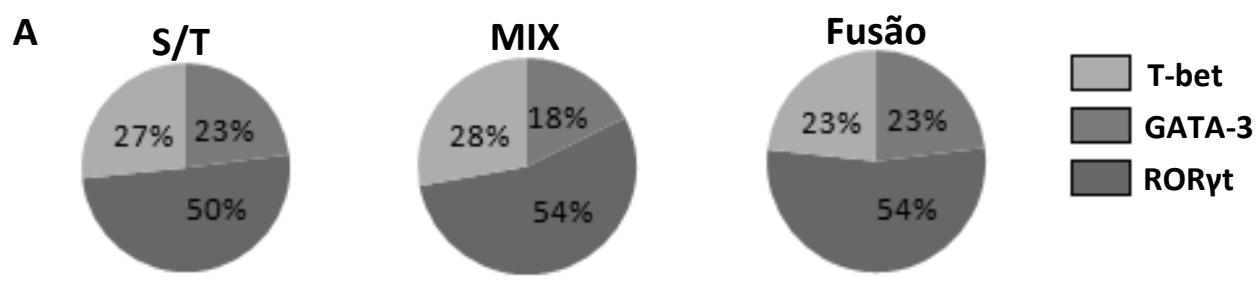

\section{B}

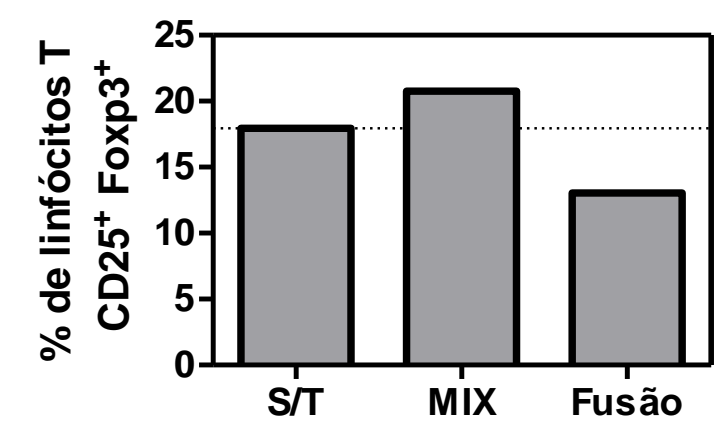

Figura 26 - Expressão de fatores de transcrição nos linfócitos T sensibilizados. (A) Proporção de linfócitos T helper expressando os fatores de transcrição T-bet (Th1), GATA-3 (Th2) e RORyt (Th17). (B) Porcentagem de linfócitos T CD4 ${ }^{+}$CD25 $5^{+}$que expressam Foxp3.

Por último, células das linhagens MDA-MB-231, MCF-7 e SK-BR-3 foram colocadas, em diferentes proporções, com os linfócitos $T$ sensibilizados, visando avaliar a capacidade citotóxica dessas células. Todas as células tumorais mostraram-se positivas para anexina $V$, mesmo na ausência de estímulos apoptóticos, o que inviabilizou esse marcador para o ensaio de citotoxicidade (dados não mostrados). As células da linhagem MDA-MB-231 foram as mais sensíveis à morte por linfócitos $T$, uma vez que mesmo os linfócitos $T$ apenas cultivados com citocinas foram capazes de induzir a morte dessas células (Figura 27). A sensibilização dos linfócitos T com MIX ou fusão parece ter sido capaz de gerar linfócitos T citotóxicos (CTLs) específicos, uma vez que a morte induzida por esses grupos foi maior do que no grupo de linfócitos $T$ que não foram sensibilizados.

Esses resultados mostram que os híbridos foram capazes de estimular a geração de linfócitos $T$ com características de células ativadas e que estes foram capazes de 
produzir citocinas pró-inflamatórias frente a um estímulo inespecífico. Os linfócitos $T$ $\mathrm{CD}^{+}$apresentaram um perfil menos regulador quando comparado aos controles e os linfócitos T CD8 ${ }^{+}$apresentaram uma capacidade citotóxica que pareceu ser específica para as células tumorais utilizadas na fusão.

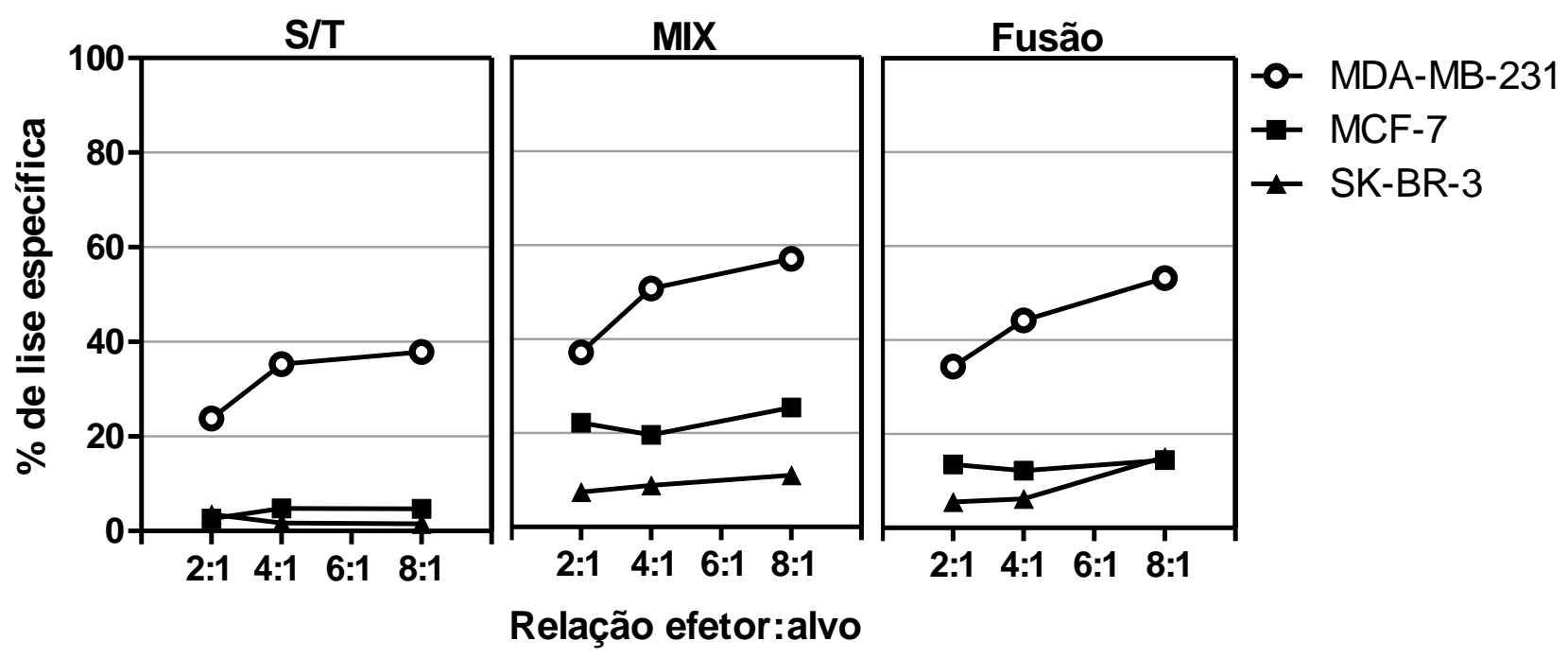

Figura 27 - Citotoxicidade induzida por linfócitos T sensibilizados pela fusão. Células das linhagens MDA-MB-231 (vermelho), MCF-7 (verde) e SK-BR-3 (azul) foram usadas como alvo de linfócitos T sensibilizados com MIX, fusão, ou apenas cultivados sem estímulos. A porcentagem de lise específica foi calculada levando-se em conta a lise espontânea das culturas.

\subsection{Indução de linfócitos T CD8 ${ }^{+}$antígeno-específicos pelos híbridos}

Dado que os híbridos pareceram induzir linfócitos T CD8 ${ }^{+}$citotóxicos específicos contra as células tumorais utilizadas na fusão, um experimento foi feito visando avaliar se esses híbridos seriam capazes de induzir linfócitos $\mathrm{T}$ citotóxicos antígeno-específicos. Para isso, foi feito um experimento de estimulação de linfócitos $\mathrm{T} \mathrm{CD8^{+ }}$ em microcultura, em um sistema biológico com quase nenhuma resposta alogeneica, de modo a eliminar ao máximo o background visando conseguir detectar uma resposta antígeno-específica. Foram utilizadas células dendríticas e linfócitos de doadores $\mathrm{HLA}-\mathrm{A} 2^{+}$e células da linhagem tumoral K562 transfectadas com HLA-A2 (aqui denominadas KA2). As células K562 são conhecidas por não apresentarem moléculas de classe I do MHC, sendo assim, nesse sistema, essas células expressarão apenas a molécula HLA-A2, também 
presente nas células dendríticas e linfócitos $T$ utilizados. Como antígeno, utilizou-se a molécula pp65, uma proteína que é conhecida por ser apresentada eficientemente no contexto das moléculas de HLA-A2 (TRAUTMANN, RIMBERT, et al., 2005).

A formação dos híbridos, nesse caso, foi avaliada utilizando-se a molécula CD86 (expressa em $96 \%$ das DCs e 1\% das KA2) e CD15 (expressa em 50\% das KA2 e 15\% das DCs). Apesar de não ser a situação ideal, foi possível perceber um aumento de células duplo-positivas no grupo eletroporado, indicando que houve a formação de híbridos (Figura 28).
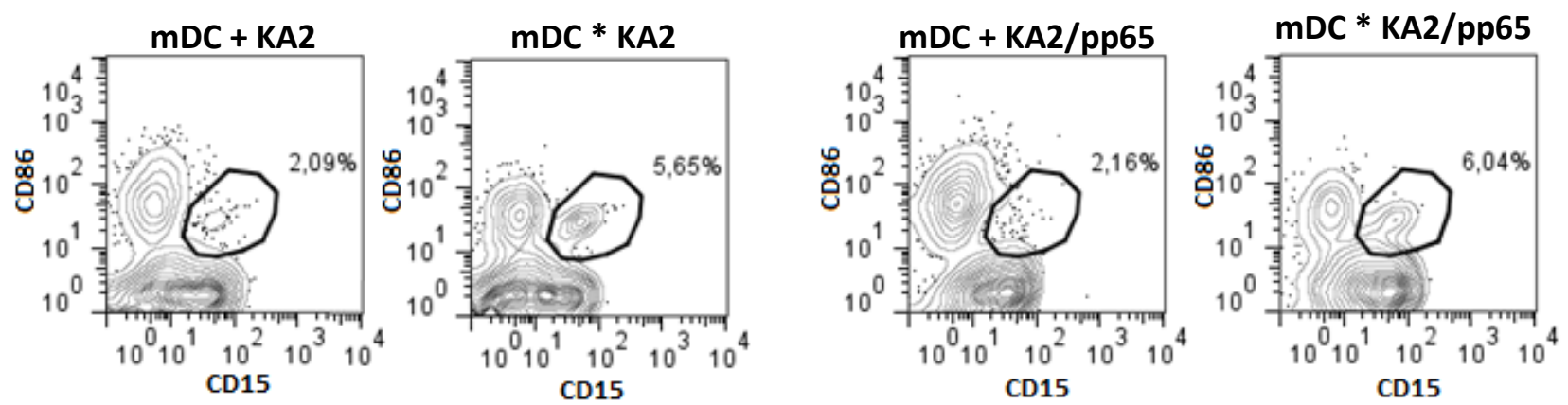

Figura 28 - Porcentagem de híbridos de DCs e células KA2. Gráfico mostrando a porcentagem de células positivas para CD15 e CD86 na mistura (representada pelo símbolo " + ") ou nos híbridos (símbolo " * ") de DCs e células da linhagem KA2 expressando ou não o antígeno pp65.

Os linfócitos $T$ foram, então, estimulados duas vezes com a mistura (aqui representada pelo símbolo "+") ou com híbridos (símbolo "*”) de DCs e KA2 expressando a proteína pp65 (KA2/pp65) ou não. O número de linfócitos T após a primeira e segunda estimulação foi determinado, sendo possível perceber que houve aumento do número de células em todos os grupos utilizados, incluindo a estimulação com mDCs sem antígenos (Figura 29).

Dado que todos os grupos apresentaram expansão de linfócitos $T$, uma análise foi feita para ver se houve uma expansão antígeno-específica, ou seja, se houve aumento da porcentagem de linfócitos $T$ específicos para pp65. Para isso, foram utilizados pentâmeros de moléculas de MHC de classe I carregadas com peptídeos de pp65 ligados a fluorocromos, sendo a aquisição feita por citometria de fluxo. Três diferentes pentâmeros foram utilizados: um pentâmero de HLA-A02 específico para pp65, um 
pentâmero de HLA-B07 específico para pp65 e um pentâmero inespecífico. Os resultados são expressos como porcentagem de linfócitos $T$ reativos ao pentâmero dentro da população de células $\mathrm{CD}^{+}$.

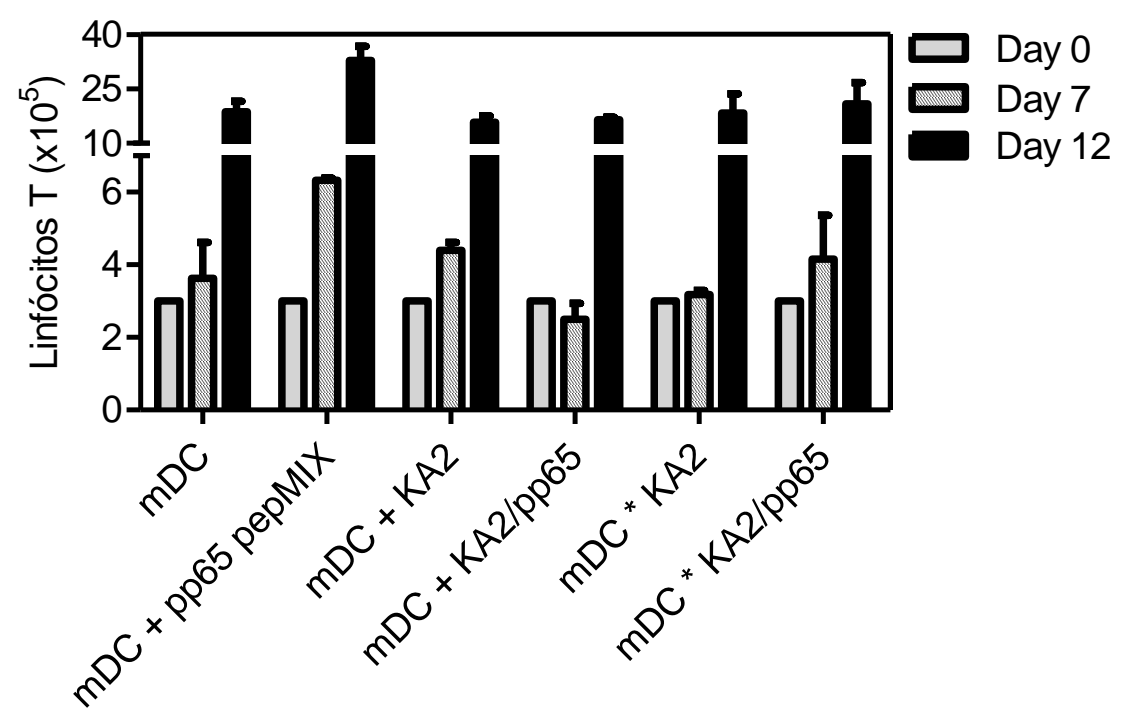

Figura 29 - Número de linfócitos T após sensibilização com híbridos. Quantidade de linfócitos T após primeira (dia 7) e segunda estimulação (dia 12) com diferentes células estimuladoras: $\mathrm{mDCs}$; mDCs carregadas com mistura de peptídeos provenientes da proteína pp65 (mDC + pp65); mistura (mDC + KA2 e mDC + KA2/pp65) ou fusão $\left(m D C *{ }^{*} \mathrm{KA} 2\right.$ e $\left.\mathrm{mDC}{ }^{*} \mathrm{KA} 2 / \mathrm{pp} 65\right)$ de $\mathrm{mDC}$ s e células tumorais sem ou com o antígeno de interesse.

Nenhum dos grupos mostrou positividade significativa para o pentâmero inespecífico (Figura 30). Os linfócitos T estimulados com DCs carregadas com peptídeos mostraram positividade parecida para os dois pentâmeros, sendo os dois em torno de $4 \%$. Nem a mistura nem a fusão de DCs com células KA2 sem o antígeno induziram uma expansão de clones específicos para a proteína pp65. Porém, tanto a fusão quando a mistura de DCs com células KA2/pp65 induziram uma expansão de clones específicos para pp65 e restritos pelo HLA-A2 superior à encontrada nos linfócitos estimulados com DCs carregadas com peptídeos. 


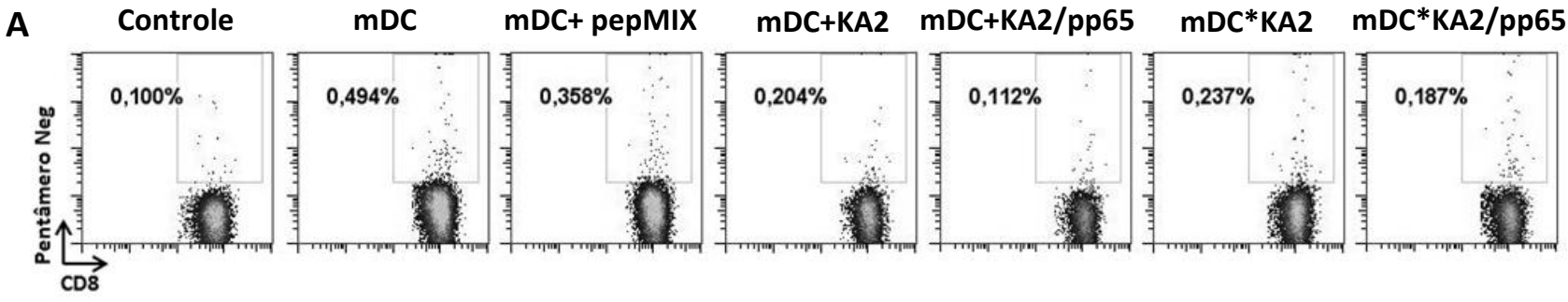

B
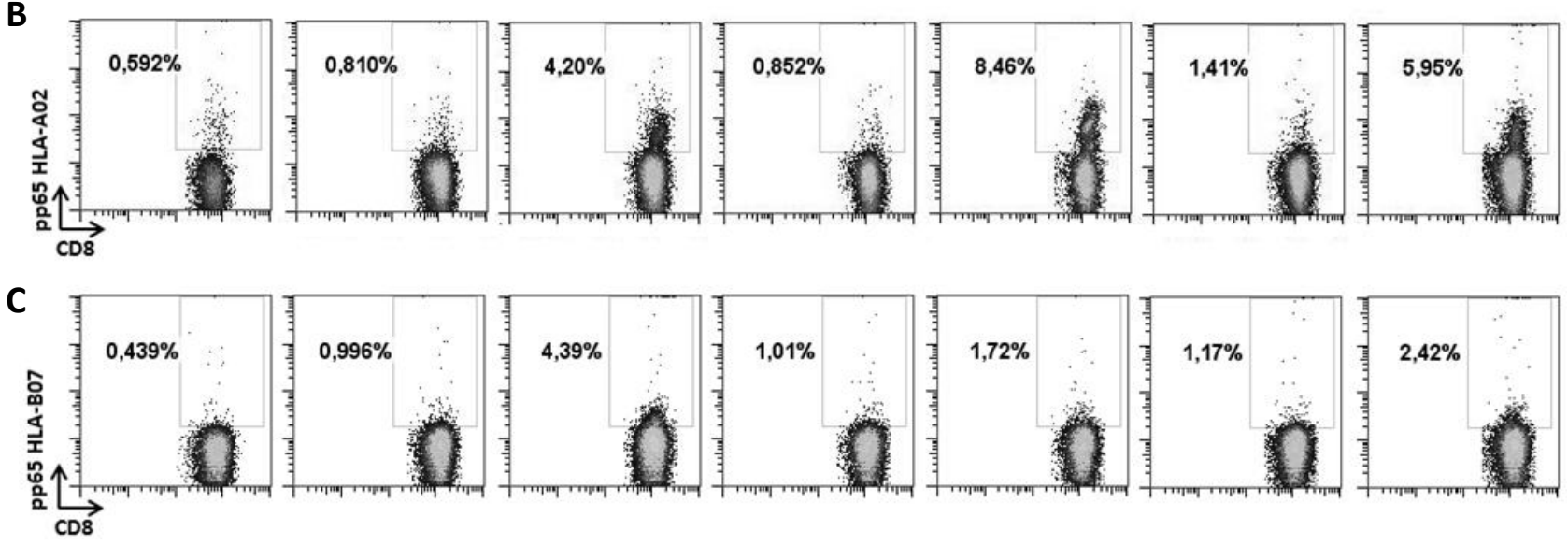

Figura 30 - Porcentagem de células positivas para cada tetrâmero. Porcentagem de linfócitos T $\mathrm{CD}^{+}$capazes de se ligar a diferentes pentâmeros após serem estimulados por 12 dias com diferentes células. (A) Pentâmero inespecífico. (B) Pentâmero de HLAA02 específico para pp65. (C) Pentâmero de HLA-B07 específico para pp65.

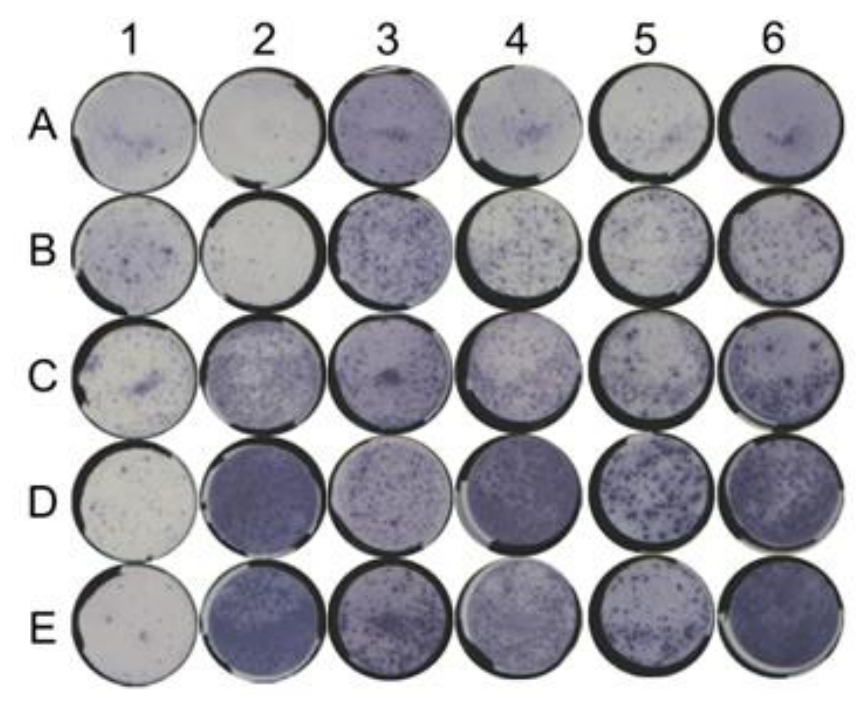

Figura 31 - Poços representativos do ELISPOT. Foto dos poços da placa de ELISPOT mostrando grupos representativos de cada amostra. (A): Linfócitos T sem estímulo; (B): Linfócitos T + KA2; (C): Linfócitos T + pp65 pepmix; (D): Linfócitos T + KA2/pp65; (E): Linfócitos $T+C E F$. Os números representam os grupos de células T estimulados com (1) mDCs; (2) mDC + pp65 pepmix; (3) mistura de mDC + KA2; (4) mistura de mDC + KA2/pp65; (5) fusão de mDC * KA2; (6) fusão de mDC * KA2/pp65. 
Com relação aos clones restritos pelo HLA-B07, o único grupo que apresentou positividade acima de $2 \%$, além das DCs estimuladas com peptídeos, foram os linfócitos T estimulados com híbridos utilizando a KA2/pp65. Dado que essa molécula do MHC só está presente nas DCs, e o antígeno estava presente apenas nas células tumorais, esse resultado mostra que os híbridos são capazes de processar e apresentar antígenos no contexto dos dois conjuntos de moléculas do MHC, cada um proveniente de um tipo celular.

Como tanto a mistura quanto a fusão foram capazes de induzir uma expansão antígeno-específica de linfócitos $\mathrm{T}$, o próximo passo consistiu em analisar se esses linfócitos eram capazes de gerar uma resposta imune, ou seja, se eram reativos contra células contendo esse antígeno. Para isso, um experimento de ELISPOT foi realizado, onde os linfócitos $T$ sensibilizados em microcultura com diferentes células foram colocados em contato com diferentes estímulos. Cada célula capaz de produzir IFN-y frente ao estímulo gerou uma pequena marca na membrana do ELISPOT (Figura 31), sendo a quantidade dessas marcas (spots) quantificada.

Apenas uma pequena quantidade de linfócitos $T$ de cada grupo foi capaz de produzir IFN-y sem a presença de um estímulo, enquanto uma quantidade maior de células produziram IFN- $\gamma$ na presença do controle positivo CEF (Figura 32A). Com relação à reatividade contra a mistura de peptídeos da proteína pp65 (pp65 pepmix), foi possível observar que apenas os linfócitos $T$ estimulados com a fusão e a mistura que usaram as células KA2/pp65, e não as que usaram as células KA2, foram capazes de induzir mais spots quando comparados com as mDCs sem antígenos (Figura 32B). Porém, novamente ambos os grupos de fusão e mistura utilizando KA2/pp65 foram capazes de induzir a mesma quantidade de linfócitos T reativos contra o pp65 pepmix.

Por último, analisou-se o número de linfócitos $\mathrm{T}$, em cada grupo, que conseguia reagir contra células KA2/pp65, mas não células KA2. Para isso, o número de spots por $10^{5}$ células observado quando os linfócitos $T$ foram cultivados com KA2/pp65 foi subtraído do número de spots de linfócitos T reativos contra as células KA2 (Figura 32C). Nenhum dos grupos estimulados por mistura de células foi capaz de induzir um grande número de linfócitos $T$ que reagem apenas á KA2/pp65. Os híbridos de células KA2 e DCs também não estimularam linfócitos $T$ reativos apenas à KA2/pp65, mas os híbridos 
utilizando células KA2/pp65 foi capaz de induzir uma grande quantidade de linfócitos T reativos apenas à KA2/pp65.

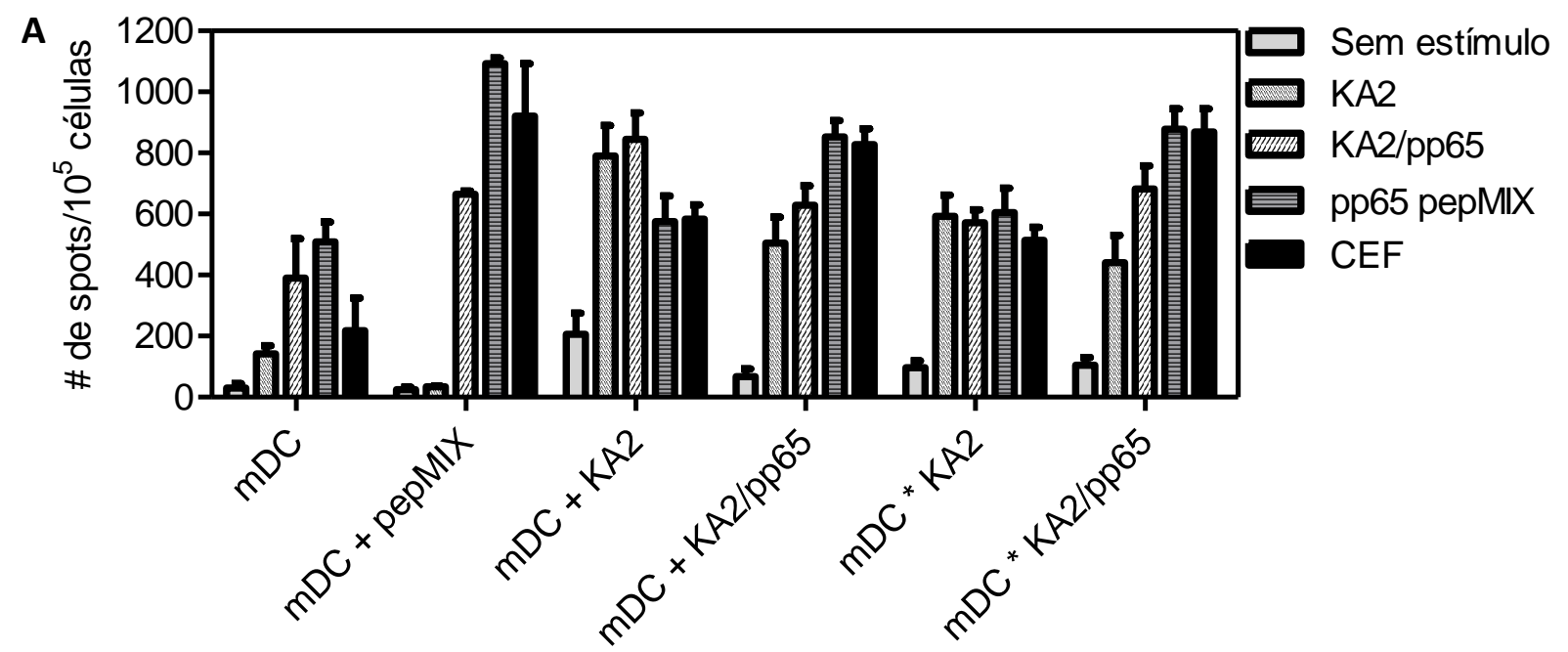

B

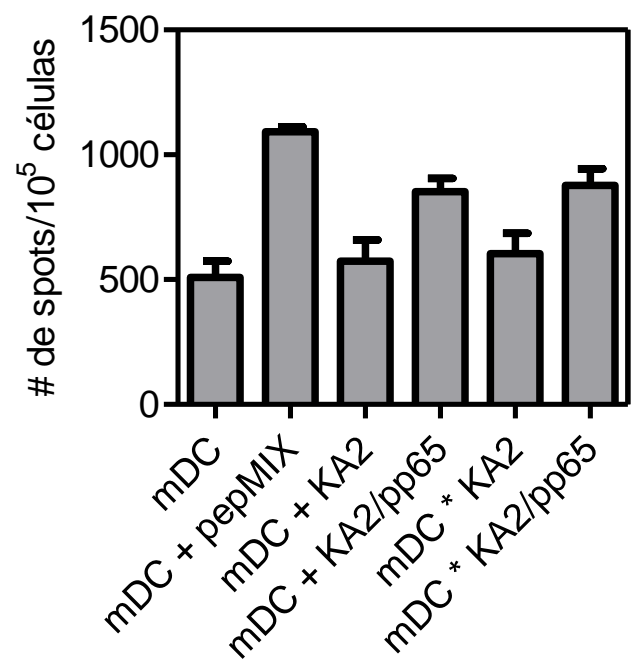

C

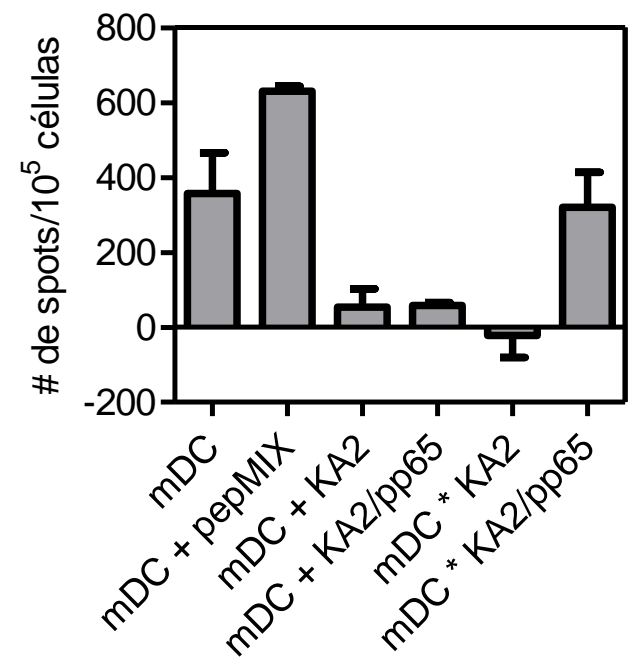

Figura 32 - Quantificação do ensaio de ELISPOT. (A) Quantidade de spots de IFN-y por $10^{5}$ linfócitos $T$ sensibilizados por diferentes células e plaqueados sozinhos, com células KA2, com células KA2/pp65, com pp65 pepmix ou com o controle positivo com

CEF $(n=5)$. (B) Número de linfócitos T que após serem sensibilizados por diferentes células, foram capazes de produzir IFN- $\gamma$ frente à mistura de peptídeos da proteína pp65

(pp65 pepMIX). (C) Número de linfócitos T por $10^{5}$ células reativos contra células KA2/pp65 subtraído do número de linfócitos $T$ por $10^{5}$ células reativos contra células KA2.

O mesmo experimento também foi realizado utilizando não células dendríticas convencionais, mas DCs diferenciadas a partir da transdução de monócitos com vírus 
contendo genes para citocinas (smyleDCs). Os resultados encontrados com essas células foram bastante similares aos obtidos com DCs convencionais (dados não mostrados).

Com esses experimentos, foi possível mostrar que, independente da maneira como as células dendríticas são obtidas, os híbridos são capazes de induzir linfócitos $T$ específicos para um antígeno presente apenas na célula tumoral. Sendo assim, os esforços foram então voltados para descobrir se seria possível enriquecer uma célula tumoral com antígenos de outra, utilizando, como estratégia, a transferência de RNA entre as células.

\subsection{Transfecção de linhagens tumorais com RNA total}

Para determinar as melhores condições de transfecção, RNA total da linhagem SK-BR-3 foi extraído e misturado com mRNA codificando a proteína GFP na proporção $9: 1$. Diversos agentes de transfecção lipídicos foram testados para descobrir qual deles apresentava a maior eficiência de transfecção, avaliada pela expressão de GFP (Figura 33). De todos os agentes testados, a Lipoanfectamina (Lipofectamine ${ }^{\circledR} 2000$ ) foi a que apresentou maior eficiência, e, portanto, foi a utilizada nos próximos experimentos. A transfecção foi também padronizada de modo a diminuir a quantidade de células mortas (dados não mostrados).
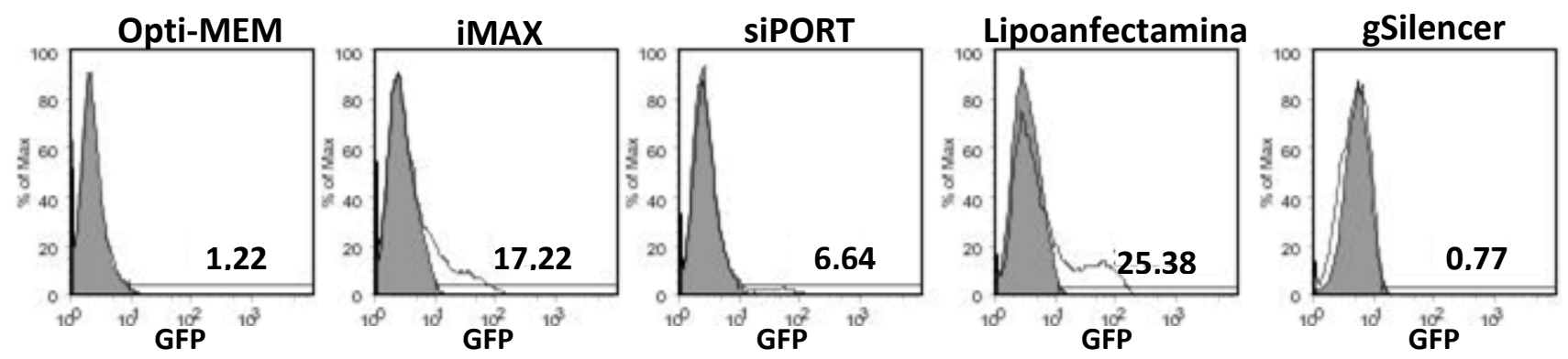

Figura 33 - Expressão de GFP após 24 h do tratamento com diferentes agentes de transfecção. Histograma da expressão de GFP por citometria de fluxo de células da linhagem MDA-MB-231 após tratamento com diferentes agentes de transfecção ou o veículo (Opti-MEM) na presença (branco) ou ausência (cinza) de RNA composto de $90 \%$ de RNA total da SK-BR-3 e 10\% de mRNA para GFP. 
Com a técnica de transfecção lipídica padronizada, analisou-se a expressão de diversas moléculas nas células transfectadas com RNA total, visando avaliar se era possível aumentar a expressão dessas moléculas quando o RNA era introduzido na célula.

Primeiramente, a expressão de ER, PR, HLA-A, HLA-DR e $\beta_{2}$-microglobulina foi analisada por real time em células da linhagem MCF-7 que foram ou não transfectadas com RNA total não amplificado de células SK-BR-3 (Figura 34). Foi possível observar um aumento na quantidade de mRNA de $\beta_{2}$-microglobulina, HLA-A e HLA-DR, mas não de ER e PR nos grupos transfectados com o RNA total.
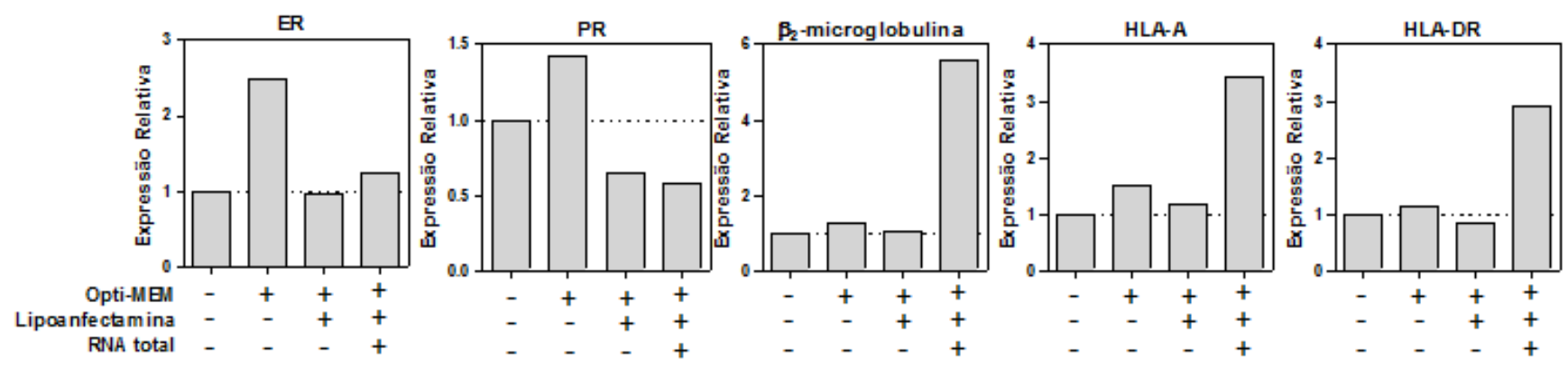

Figura 34 - Expressão relativa de diferentes mRNAs após transfecção com RNA total. Análise de real time PCR da quantidade de mRNA presente em células MCF-7 tratadas ou não com lipoanfectamina com RNA total da SK-BR-3.

Em seguida, analisou-se a expressão de membrana das moléculas de Her2/neu, HLA-ABC e HLA-DR em células das linhagens MCF-7 e MDA_MB-231 transfectadas ou não com RNA total da SK-BR-3. Não foi possível observar diferença na expressão das moléculas HLA-DR e Her2/neu na superfície das células MCF-7 e MDA-MB-231 tratadas com RNA total (dados não mostrados).

Curiosamente, o aumento das moléculas de HLA-ABC na membrana das células só foi observado quando as células transfectadas com o RNA total da SK-BR-3 eram da linhagem MCF-7, e não quando eram células da linhagem MDA-MB-231 (Figura 35). A maioria das células que tiveram aumento de expressão de HLA-ABC eram células positivas para GFP, ou seja, células que foram transfectadas eficientemente. 

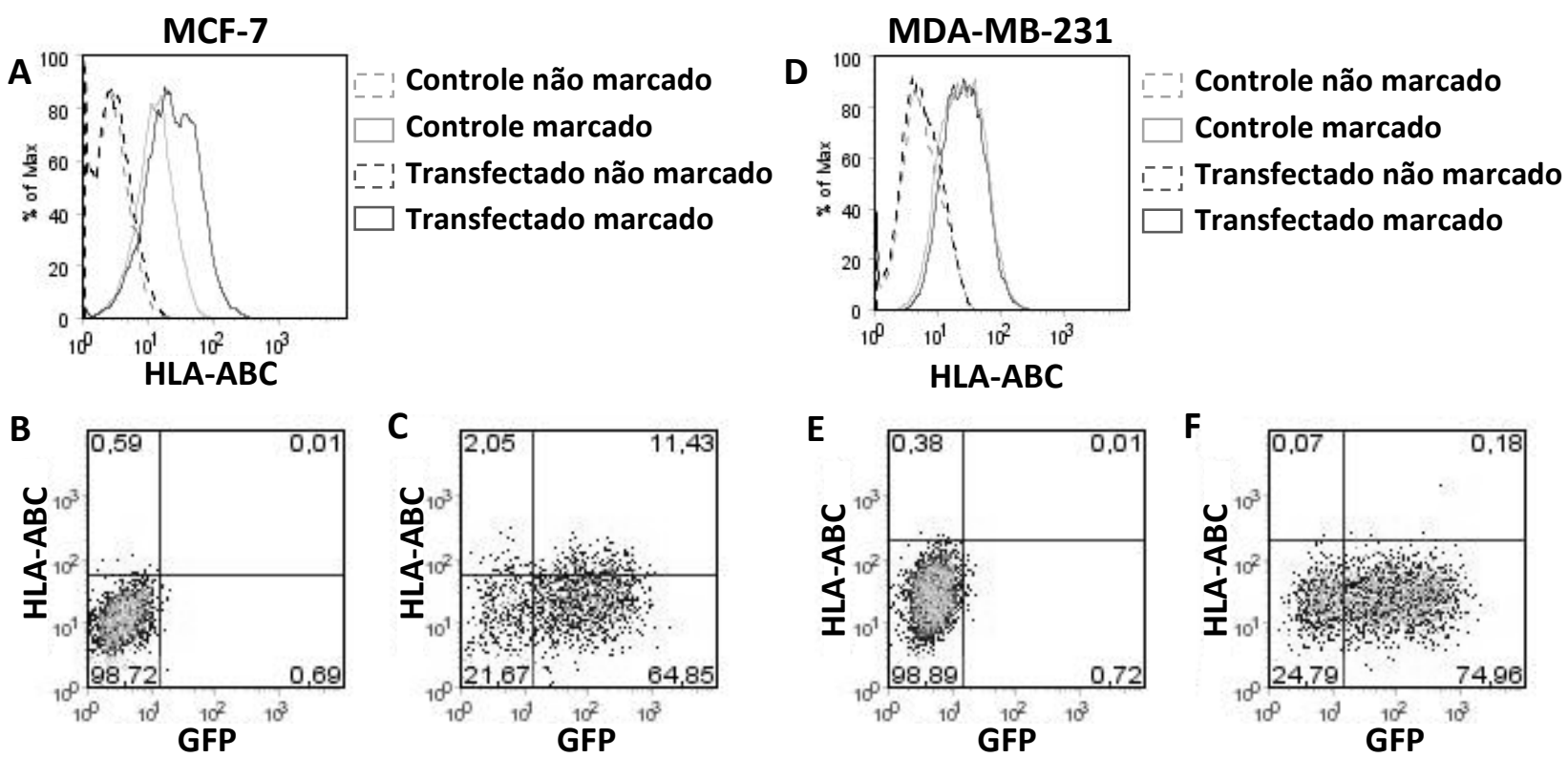

Figura 35 - Expressão de HLA-ABC nas células transfectadas ou não com RNA tumoral total da SK-BR-3. Expressão de HLA-ABC em células da linhagem MCF-7 (esquerda) e MDA-MB-231 (direita). (A) Histograma de HLA-ABC em células da linhagem MCF-7 tratadas com lipoanfectamina na presença (azul) ou ausência (vermelho) de RNA total. Expressão de GFP e HLA-ABC por células da linhagem MCF-7 tratadas com (B) lipoanfectamina ou com (C) lipoanfectamina + RNA. (D) Histograma de HLA-ABC em células da linhagem MDA-MB-231 tratadas com lipoanfectamina na presença (azul) ou ausência (vermelho) de RNA total. Expressão de GFP e HLA-ABC por células da linhagem MDA-MB-231 tratadas com (E) lipoanfectamina ou com (F) lipoanfectamina + RNA. Os gates foram feitos considerando a expressão de HLA-ABC e GFP nas células não transfectadas.
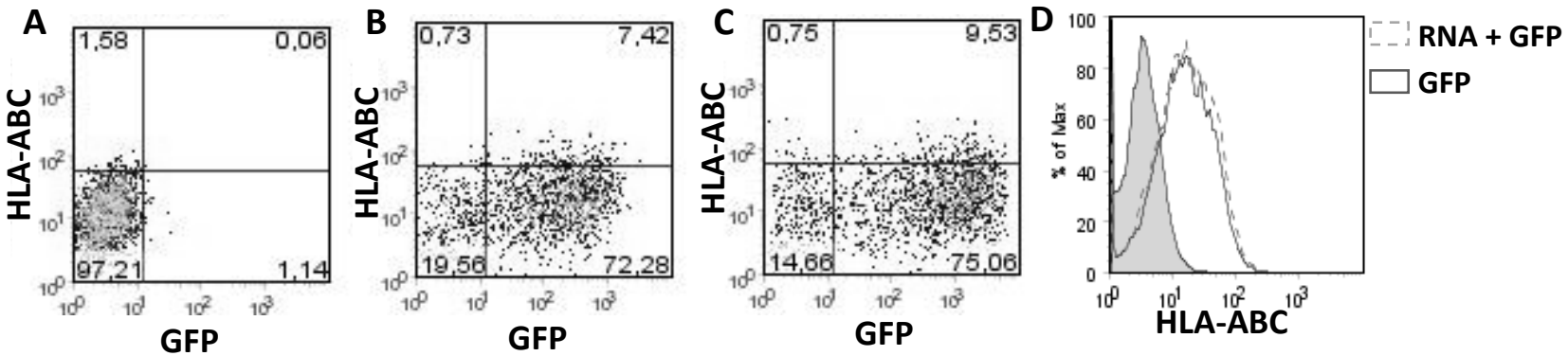

Figura 36 - Expressão de HLA-ABC em células transfectadas apenas com mRNA que codifica o GFP. Gráfico de pontos (dot plot) mostrando a expressão de GFP e HLA$A B C$ em células transfectadas. (A) Lipoanfectamina. (B) Lipoanfectamina + RNA total com $10 \%$ de mRNA para GFP. (C) Lipoanfectamina + mRNA para GFP. (D) Histograma de HLA-ABC em células da linhagem MCF-7 tratadas com lipoanfectamina e GFP na presença (vermelho) ou ausência (azul) de RNA total. 
As células da linhagem MCF-7 foram, então, transfectadas apenas com GFP, visando verificar se o aumento de HLA-ABC foi devido à expressão do mRNA transfectado ou se foi um efeito secundário da transfecção, ou seja, se a MCF-7, mas não a MDA-MB-231, teria algum mecanismo que induziria o aumento da expressão de HLA-ABC por causa do processo da transfecção. Mesmo transfectando a célula apenas com mRNA que codifica o GFP, o aumento da expressão de HLA-ABC nas células da linhagem MCF-7 continuou sendo observado (Figura 36). Sendo assim, podemos inferir que a MCF-7 tem sim um mecanismo que induz o aumento de HLA-ABC, independente da sequência do mRNA transfectado. Isso, porém, não exclui a possibilidade de parte de esse efeito ser devido à expressão de HLA-ABC da SK-BR-3, uma vez que, apesar de não expressar essas moléculas em sua superfície, a SK-BR-3 apresenta mRNA para essas moléculas.

Portanto, apesar de ter sido detectado aumento no nível de mRNA de algumas moléculas, não foi possível detectar um aumento do nível proteico, que fosse devido à expressão do mRNA transfectado, de nenhuma das moléculas analisadas após o processo de transfecção. Então, para determinar se o mRNA transfectado é capaz de ser traduzido na célula, células da linhagem MDA-MB-231 foram transfectadas apenas com mRNA para GFP e tiveram seu RNA extraído, sendo esse transfectado em novas células da linhagem MDA-MB-231. 50\% das células MDA-MB-231 que foram transfectadas com mRNA para GFP ficaram verdes(Figura 37A), sendo o mRNA dessas células extraído e transfectado em novas células. As células transfectadas com esse RNA apresentaram positividade para GFP (Figura 37B), sendo mais de 30\% delas positivas para GFP. Tal fenômeno foi observado em três experimentos independentes.

Esses experimentos mostram que é possível que a transferência do RNA de uma célula para outra gere a expressão de proteínas cujos mRNAs estejam presentes na célula doadora do mRNA. Sendo assim, o próximo passo foi verificar se é possível amplificar o mRNA mensageiro de uma célula, de modo que poucas células tumorais tenham RNA suficiente para que sejam feitas diversas transfecções. 


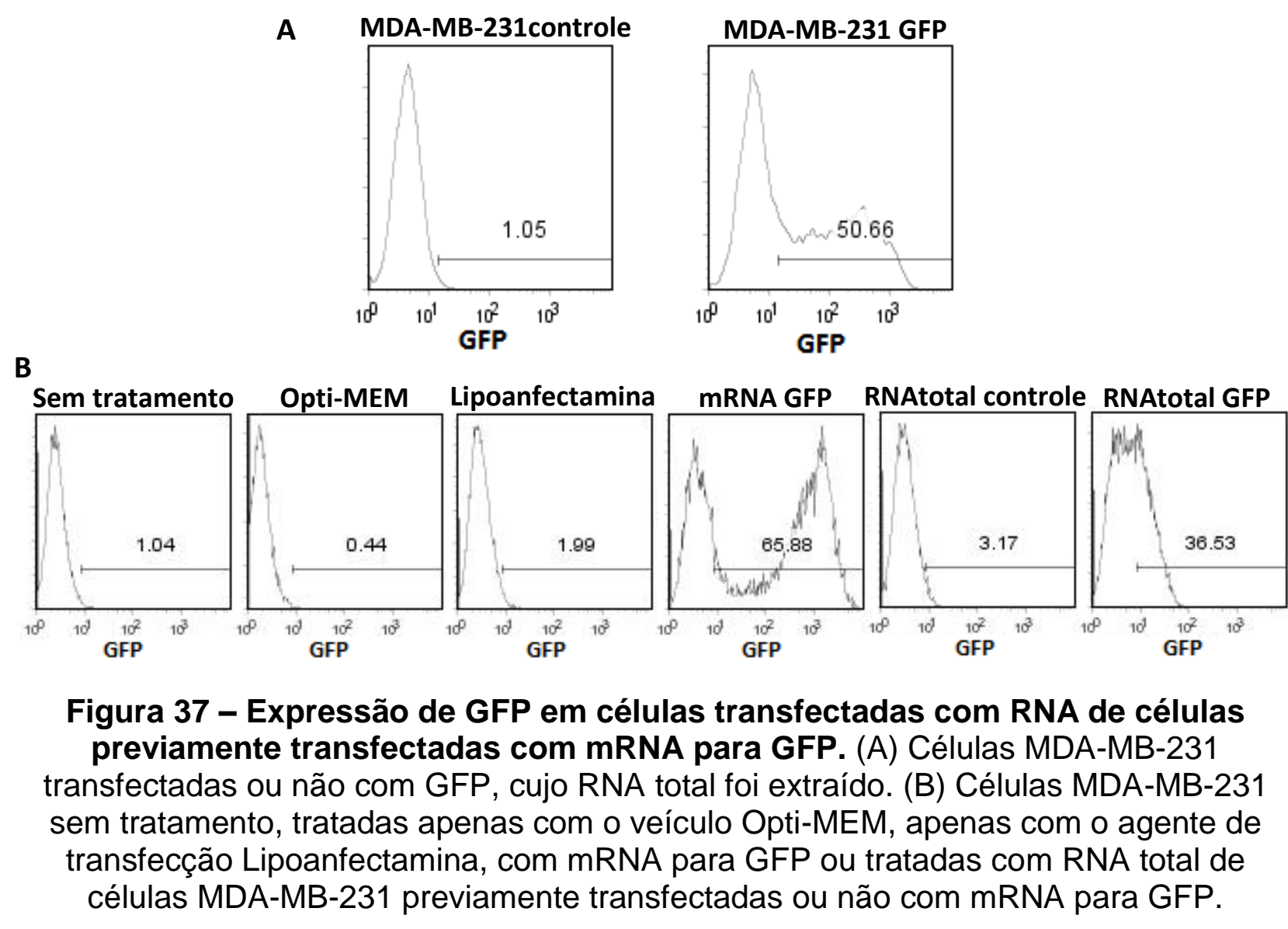

\subsection{Amplificação do mRNA tumoral e transfecção do mRNA amplificado}

O mRNA das células da linhagem tumoral SK-BR-3 foi amplificado como previamente utilizado na literatura, e descrito nas sessões 3.25 e 3.26. Para saber quais os tamanhos de fragmentos estavam sendo amplificados pelo processo, foi feito um gel de agarose com $800 \mathrm{ng}$ de ácidos nucleicos de cada etapa do processo, tratados ou não com DNAse (Figura 38). Como esperado, foi possível distinguir as duas bandas dos RNAs ribossomais no produto do RNA total. Não foi possível visualizar a banda do RNA da subunidade $18 \mathrm{~S}$ no produto da RT-PCR, e a banda do RNA da subunidade $28 \mathrm{~S}$ perdeu um pouco de intensidade. Após a reação de PCR, foi possível observar uma banda forte de 200 bp, que não estava presente antes da reação de PCR. Foi possível observar um rastro de material genético no produto da transcrição in vitro, compreendendo desde moléculas pequenas, até moléculas com tamanhos superiores a $5.000 \mathrm{bp}$ (tamanho correspondente à banda $28 \mathrm{~S}$ em humanos). Estes resultados eram 
parcialmente esperados, embora parte deles ainda esteja além de nossa possibilidade de explicação, como será discutido adiante.

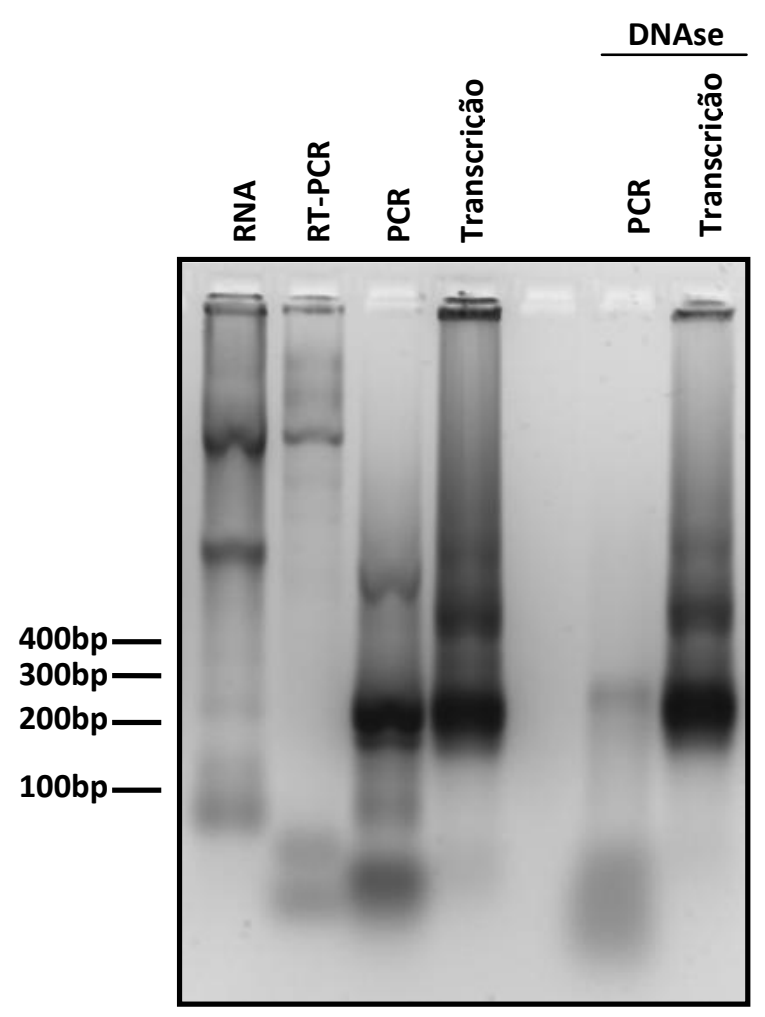

Figura 38 - Análise do tamanho dos ácidos nucleicos presentes no produto da amplificação e transcrição do RNA total. Negativo do gel de agarose com o produto de cada etapa do processo de amplificação e transcrição in vitro.

Para verificar se o procedimento de transcrição ocorreu corretamente, o produto da PCR e da transcrição foram submetidos a um tratamento com DNAse. Como pode ser observado na figura 38, o produto da PCR foi degradado praticamente por completo, enquanto o produto da transcrição quase não sofreu alteração com o tratamento. Como a PCR amplifica os fragmentos de cDNA que foram feitos na RT-PCR, era de se esperar que seu produto fosse ser, em sua maioria, DNA e, portando, deveria ser degradado na presença da DNAse, o que de fato ocorreu. A reação de transcrição, por sua vez, utiliza esses fragmentos de DNA para gerar novas moléculas de mRNA. O produto da transcrição, portanto, deveria ser composto majoritariamente de mRNA caso a reação tenha ocorrido como esperado. De fato, apenas uma pequena fração do produto da 
transcrição foi degradada pela DNAse, o que mostra que o processo de transcrição ocorreu como esperado.

Por último, avaliou-se a presença de mRNA específico para algumas moléculas antes e depois do processo de amplificação (Figura 39). Foi possível observar a presença de mRNA para Her2/neu, $\beta_{2}$-microglobulina e $\beta$-actina antes e após a amplificação. Porém, foi possível observar uma banda fraca no controle negativo (grupo sem ácidos nucleicos) da molécula $\beta$-actina, indicando que a banda observada para esse mRNA pode não ter sido totalmente específica. mRNAs codificando as moléculas HLA-A e ER, porém, foram detectados apenas no extrato total, não tendo aparecido após a amplificação. Já para a molécula PR, observou-se uma banda fraca antes da amplificação e uma banda muito mais intensa após a amplificação do mRNA.

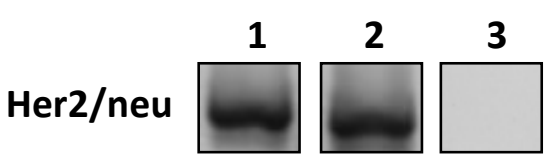

$\beta_{2}$-microglobulina
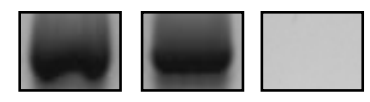

$\beta$-actina

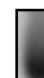
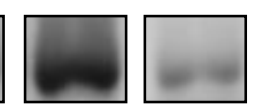

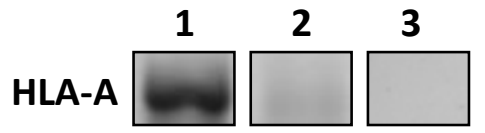

ER

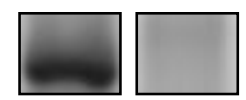

PR

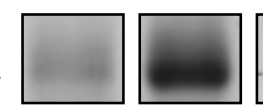

\section{1: RNA total}

2: mRNA amplificado

3: Controle negativo

Figura 39 - Expressão de mRNAs específicos antes e após a amplificação do

mRNA tumoral. Gel de agarose mostrando a presença ou ausência de mRNAs específicos para Her2/neu, $\beta_{2}$-microglobulina, $\beta$-actina, HLA-A, ER e PR antes e após a amplificação do RNA tumoral. O RNA total da SK-BR-3 e o produto da amplificação e transcrição in vitro desse RNA foram submetidos a uma transcrição reversa seguido da amplificação de sequências específicas de alguns mRNAs por PCR convencional.

Em seguida, o mRNA obtido pelo processo de amplificação acima foi misturado com 10\% de mRNA para GFP e transfectado em células da linhagem MDA-MB-231. Não foi possível, porém, observar expressão de GFP em nenhum dos tempos analisados (dados não mostrados). As células tratadas apenas com o agente de transfecção sobreviveram às $72 \mathrm{~h}$ de cultura; as células tratadas com a lipoanfectamina e o mRNA amplificado, porém, em sua maioria morreram, aparecendo grande quantidade de restos celulares na cultura, mostrando que a presença do mRNA amplificado foi tóxica para as células (Figura 40). 
A

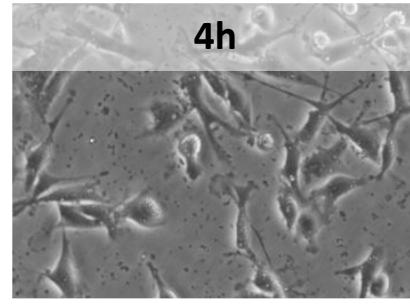

B

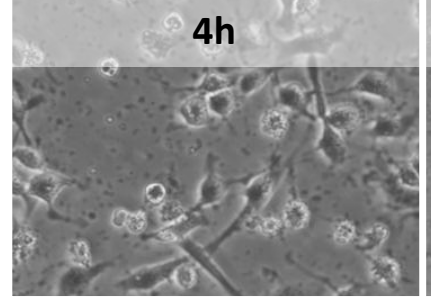

$24 h$

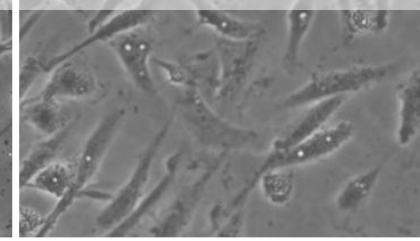

$24 \mathrm{~h}$
$48 h$

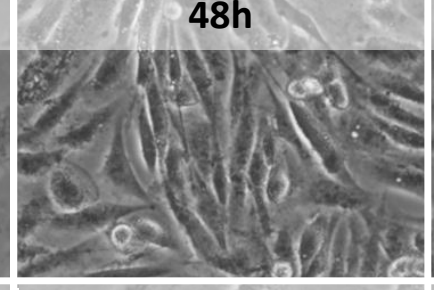

$48 h$
$72 \mathrm{~h}$

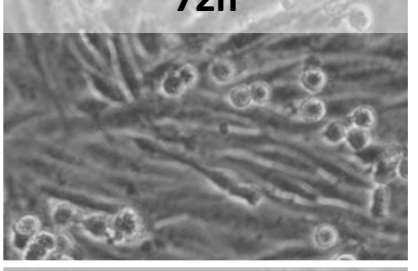

$72 \mathrm{~h}$
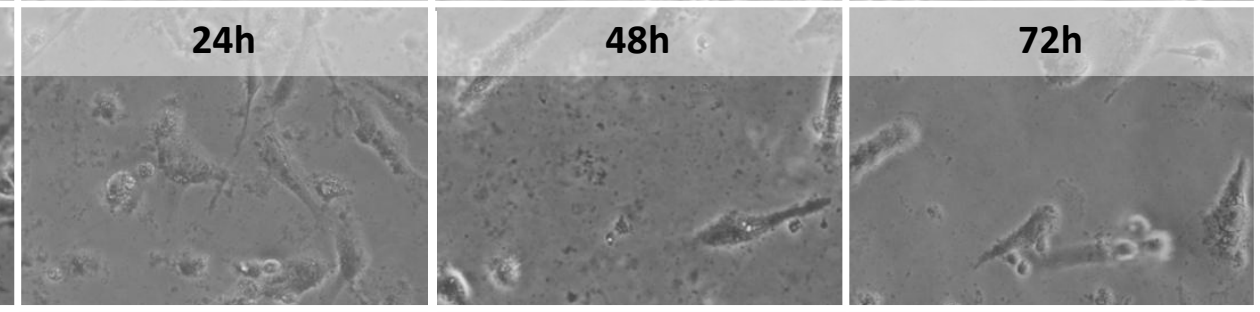

Figura 40 - Fotos das células tratadas com mRNA amplificado. Fotos das células da linhagem MDA-MB-231 após diferentes tempos do tratamento com lipoanfectamina na ausência ou presença de mRNA amplificado. (A) Lipoanfectamina. (B) Lipoanfectamina + mRNA amplificado.

Como não houve marcação com GFP, um experimento foi feito comparando a transfecção do RNA total com o mRNA amplificado. Novamente, foi possível observar que o grupo tratado com RNA total apresentava expressão de GFP enquanto o grupo tratado com mRNA amplificado não. Portanto, a falta de expressão do mRNA para GFP não foi devido à degradação do mesmo (dados não mostrados).

Para testar se esse efeito era específico da linhagem MDA-MB-231, a transfecção com RNA total e mRNA amplificado foi feita também em células da linhagem MCF-7. As duas linhagens tiveram resultados semelhantes, expressando GFP quando eram transfectadas com o RNA total, mas não expressando quando eram transfectadas com o mRNA amplificado (Figura 41). O mesmo efeito aconteceu quando se transfectou iDCs com RNA total ou mRNA amplificado (dados não mostrados). Mesmo variando as condições de transfecção (quantidade de lipoanfectamina e de mRNA amplificado), não foi possível observar uma melhora no fenótipo das células.

Ao se transfectar o RNA total, além do mRNA, também são incorporados RNAs transportadores e ribossômicos, que podem ajudar a célula a lidar com a maior carga de mRNA a ser transcrito, o que não ocorre quando se transfecta apenas o mRNA amplificado. Para verificar se esse era o motivo da falta de expressão de GFP, foi testada a transfecção de misturas com diferentes porcentagens de mRNA amplificado e RNA 
total, além dos $10 \%$ de mRNA para GFP. Porém, nenhuma mistura apresentou expressão de GFP (dados não mostrados), enfraquecendo, portanto, a hipótese.
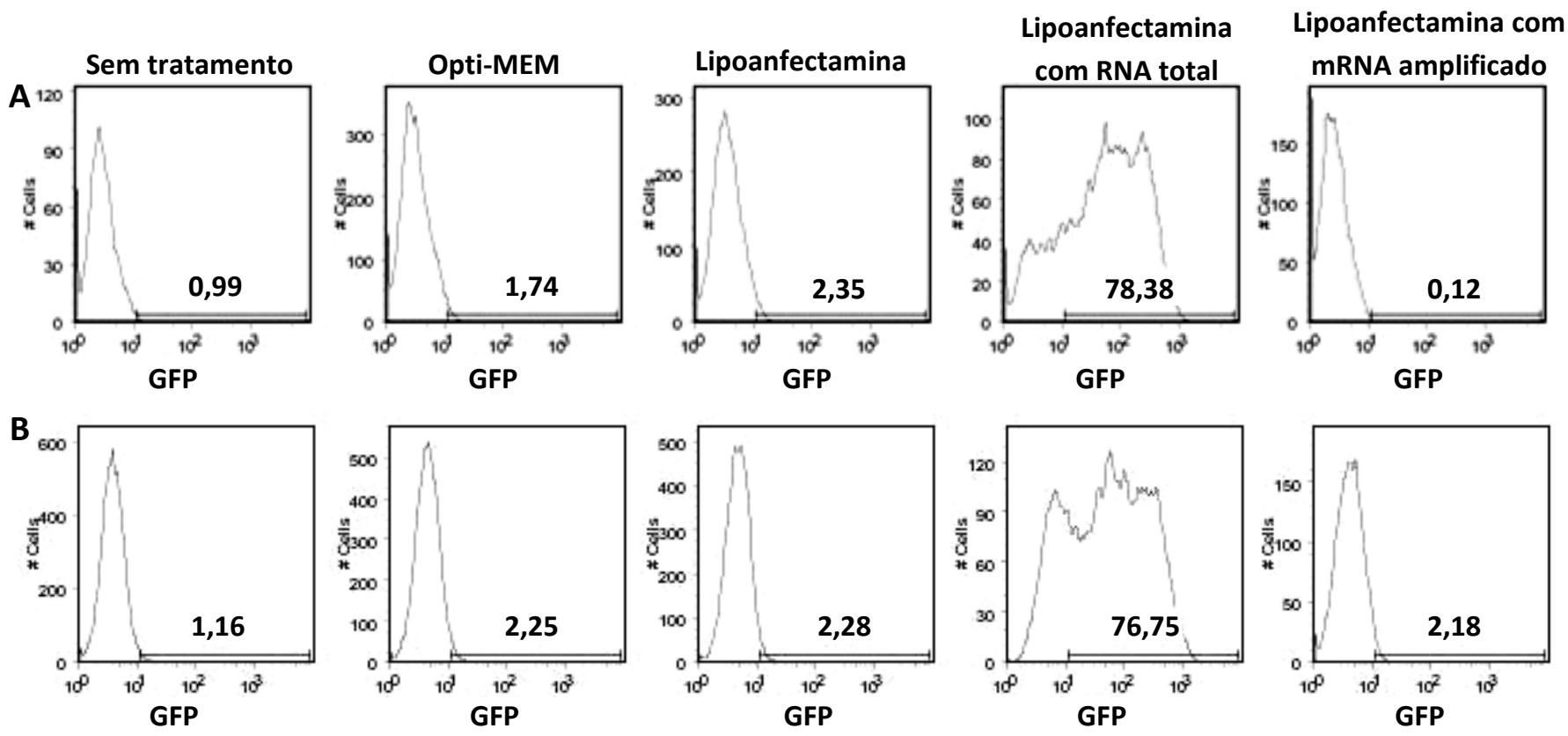

Figura 41 - Expressão de GFP em células MCF-7 e MDA-MB-231 transfectadas com RNA total ou mRNA amplificado. Porcentagem de células expressando GFP após $24 \mathrm{~h}$ da transfecção com RNA total misturado com $10 \%$ de mRNA para GFP ou mRNA amplificado misturado com 10\% de mRNA para GFP. (A) Células da linhagem MCF-7. (B) Células da linhagem MDA-MB-231

O processo de amplificação e transcrição in vitro requer uma grande quantidade de enzimas diferentes que ficam, apesar de inativas, na solução do mRNA amplificado a ser usado na transfecção. Para testar se não foram essas proteínas que atrapalharam a transfecção e mataram as células, o produto da amplificação foi submetido a uma extração com trizol, e transfectado em células da linhagem MCF-7. Esse tratamento, porém, não foi capaz de gerar a expressão de GFP nas células (dados não mostrados).

Outra estratégia utilizada foi a transfecção com diluições seriadas do mRNA amplificado, até a concentração de 15,625 ng, que é muito menor do que a quantidade mínima sugerida para esse tipo de transfecção (2000 ng). Ao contrário do mRNA amplificado, o RNA total contém apenas cerca de 5\% de mRNA; portanto, a falta de expressão poderia ser devido a grande quantidade de mRNA sendo utilizado. Apesar do MFI e da porcentagem de células terem aumentado com a diminuição do mRNA 
amplificado, esse aumento foi pequeno quando comparado com o grupo contendo apenas GFP (Figura 42). Portanto, não foi o fato de existirem muitas moléculas de mRNA que estava atando as células, uma vez que além dos resultados mostrados, a transfecção com 1500 ng de mRNA para GFP não diminuiu a viabilidade das células, que em sua maioria ficaram positivas para o GFP.

A

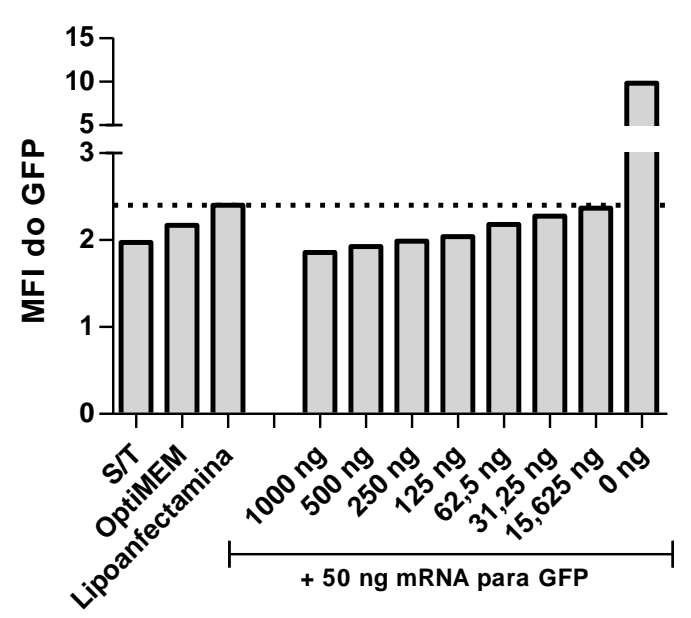

B

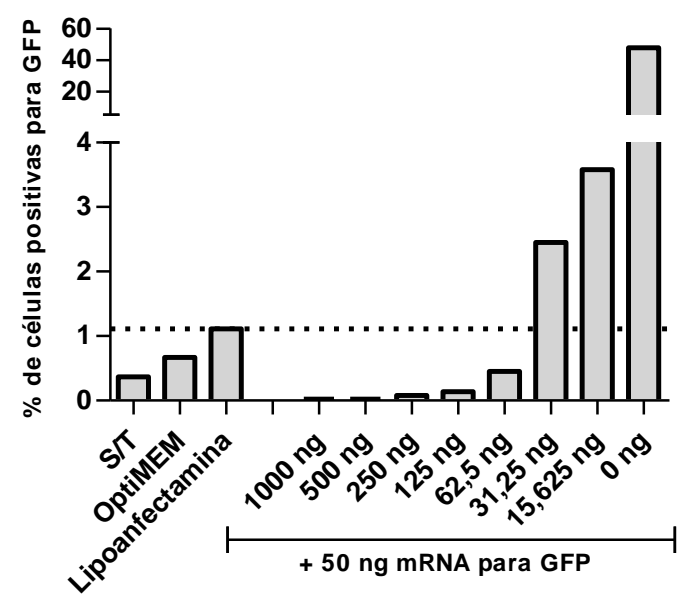

Figura 42 - Transfecção com diluições seriadas de mRNA amplificado. (A) Intensidade mediana de fluorescência ou (B) porcentagem de células positivas para GFP em células transfectadas com diferentes concentrações de mRNA amplificado e 50 ng de GFP

Logo, mesmo modificando as condições de transfecção, diminuindo a quantidade de mRNA usado e retirando as proteínas presentes no mRNA amplificado, não foi possível observar uma quantidade expressiva de células positivas para GFP nas células tradadas com mRNA amplificado e 10\% de mRNA para GFP, sejam elas de origem tumoral, ou DCs.

Como a reação de PCR inespecífica gerou uma banda de 200 bp que não estava presente antes da amplificação (Figura 38), formulou-se a hipótese de que essa banda poderia estar sendo a responsável pela morte das células, uma vez que a maioria dos mRNAs humanos se encontra acima dessa faixa de tamanho. Para testar essa hipótese, o produto da PCR inespecífica foi separado em três tubos, de acordo com o tamanho dos fragmentos (Figura 43A). Após a separação, o cDNA das três regiões, assim como o cDNA total, foram submetidos a uma reação de amplificação. 


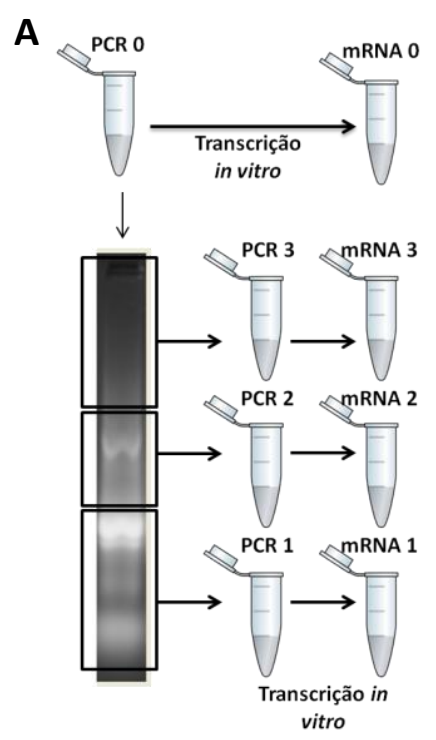

B
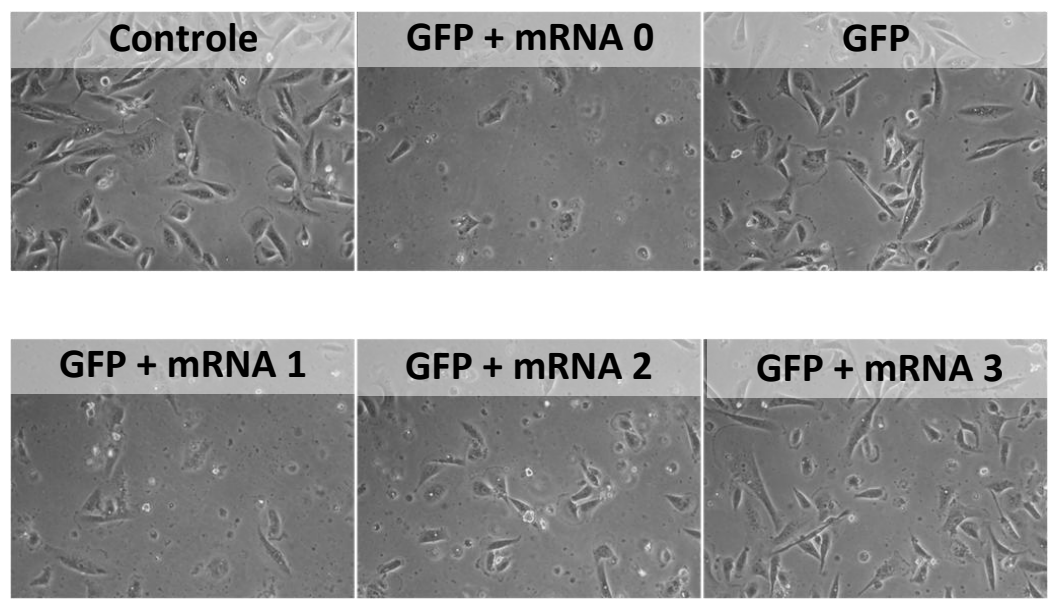

C
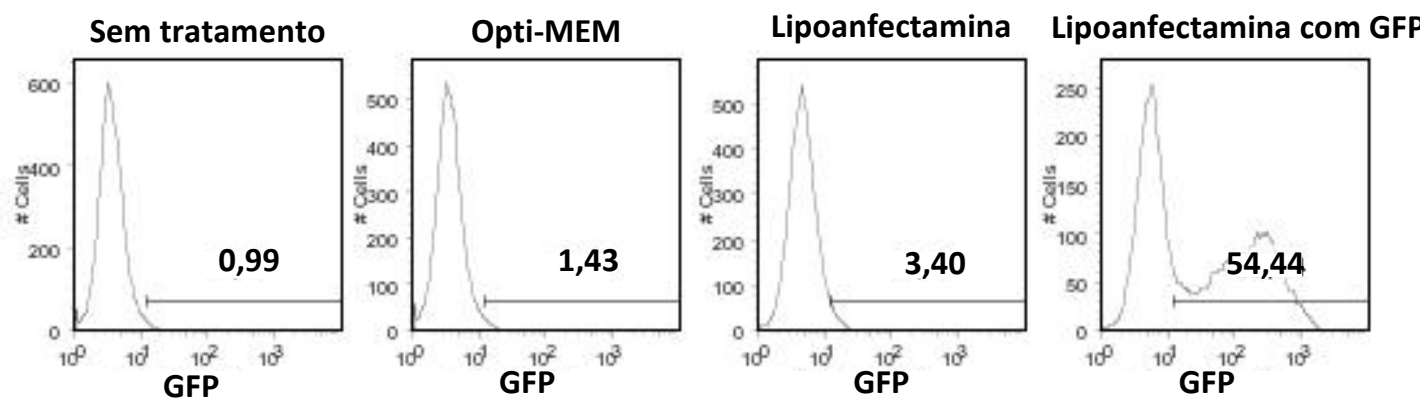

Lipoanfectamina com

Lipoanfectamina com

Lipoanfectamina com

Lipoanfectamina com
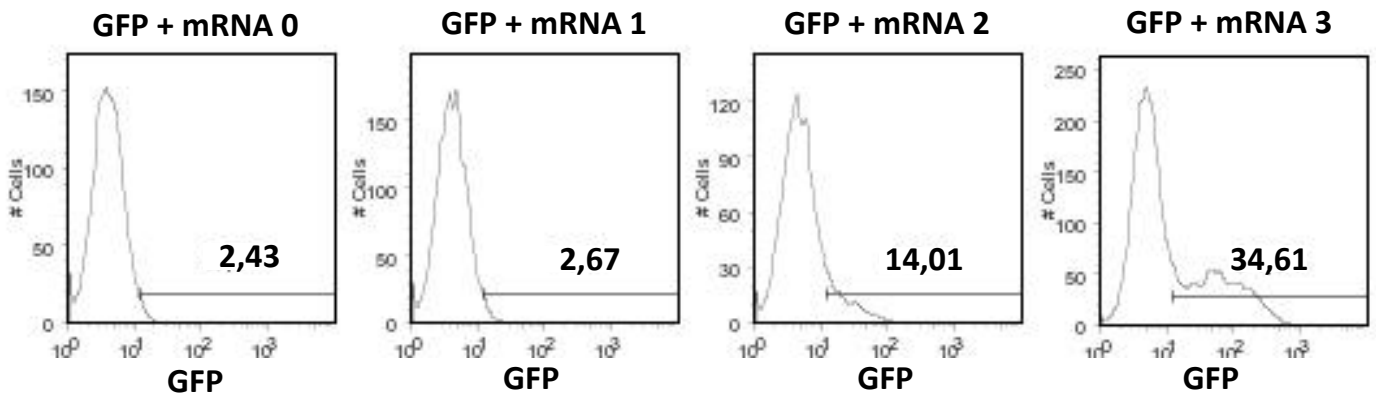

Figura 43 - Amplificação de diferentes frações da PCR inespecífica seguido de transfecção. (A) Esquema ilustrando a separação do produto da PCR em três frações de acordo com o tamanho dos cDNAs, com posterior transcrição in vitro de cada uma das porções obtidas. (B) Fotos das células da linhagem MDA-MB-231 após $24 \mathrm{~h}$ do tratamento com lipoanfectamina na ausência (Controle) ou presença de GFP e do mRNA amplificado das diferentes frações do produto da PCR (1,2 e 3) ou do mRNA total amplificado (mRNA 0). (C) Histogramas da expressão de GFP em células da linhagem MDA-MB-231 após $24 \mathrm{~h}$ da transfecção de GFP e do mRNA total amplificado (mRNA 0 ) ou do mRNA obtido de diferentes frações do RNA tumoral da SK-BR-3 amplificado por uma PCR inespecífica (1,2 e 3). 
Em seguida, células da linhagem MDA-MB-231 foram transfectadas com o produto da transcrição in vitro das três diferentes frações da PCR. As células tratadas com a fração com menor tamanho molecular (fração 1) apresentaram morfologia parecida com a observada no grupo tratado com o mRNA amplificado total (mRNA 0), enquanto as tratadas com os maiores mRNAs (fração 3) ficaram similares morfologicamente com as células tratadas apenas com GFP (Figura 43B). Observou-se também uma porcentagem crescente de células positivas para GFP nos grupos tratados com as frações crescentes de tamanho do mRNA (Figura 43C).

Por último, ao invés de separar as frações após a PCR, a separação foi feita antes da amplificação e cada fração foi submetida à reação de PCR e transcrita separadamente. Nenhuma das três frações nesse caso gerou expressão de GFP, e todas levaram à morte celular de maneira equivalente ao grupo tratado com mRNA amplificado total (dados não mostrados). Foi possível observar que, após passar pela reação de PCR inespecífica, as três frações de cDNA apresentaram uma banda forte em torno de $200 \mathrm{bp}$, na mesma região onde a banda do cDNA total era encontrada.

Sendo assim, postulou-se que a banda de 200 bp provavelmente não era devido à amplificação específica de um mRNA pequeno que estava matando a célula, e sim que a PCR não estava conseguindo amplificar a sequência completa do cDNA. Para testar tal hipótese, mRNA do GFP foi amplificado pelo mesmo processo descrito anteriormente (Figura 44). O cDNA obtido desse mRNA apresentou uma banda única, além do excesso de primers da reação. Porém, o produto da PCR apresentou a banda de 200 bp que estava sendo observada no produto de amplificação do RNA tumoral, além de uma banda bem menor do que a esperada para o produto do GFP. Esse produto, quando transfectado em células tumorais, matou as mesmas (dados não mostrados). A transfecção apenas com a fração dos mRNAs amplificados de maior tamanho não foi citotóxica mas também não gerou expressão de GFP nas células tumorais, mostrando que a reação de PCR não estava gerando produtos íntegros, e, portanto, precisava ser modificada. 


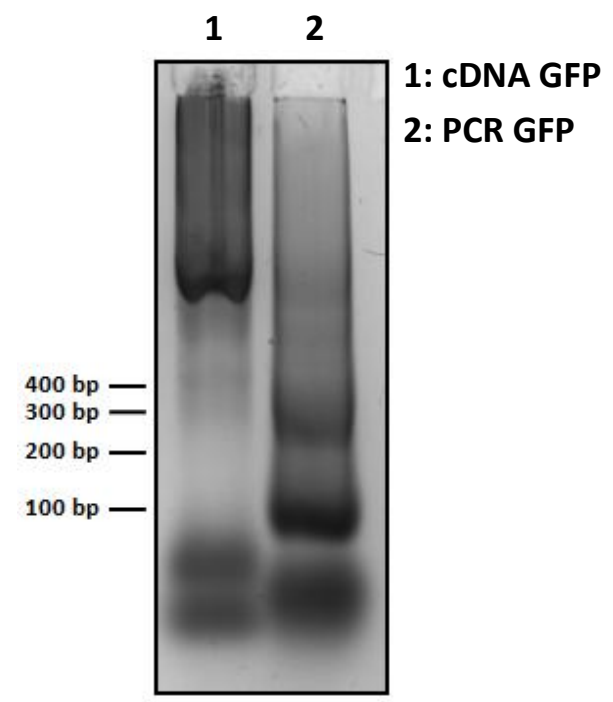

Figura 44 - Amplificação d GFP com protocolo padrão. Negativo da foto do gel de agarose do produto da reação de transcrição reversa do mRNA para GFP e da PCR do cDNA obtido.

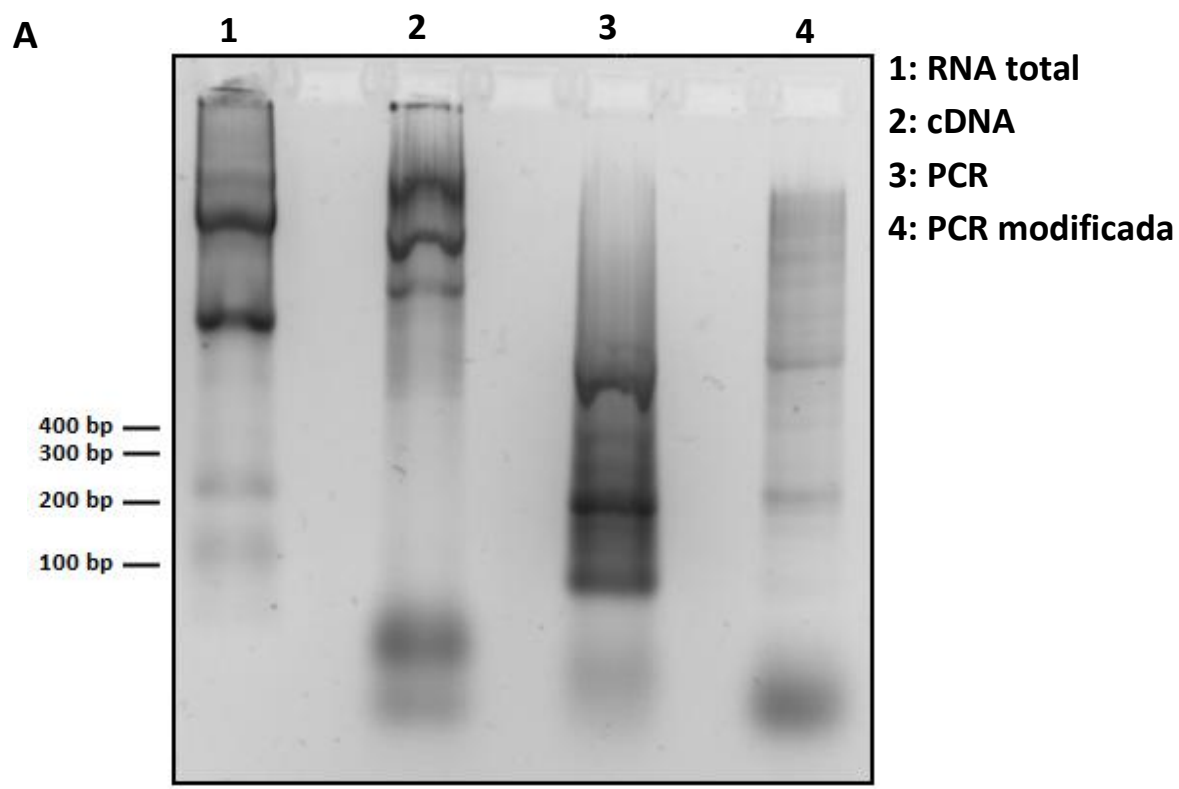

B

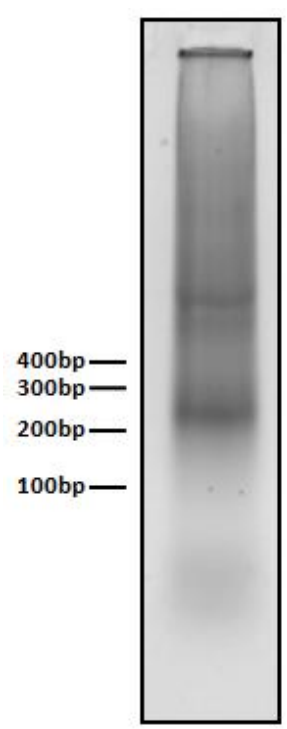

Figura 45 - Produto da PCR do RNA total com condições de amplificação alteradas. (A) Negativo da foto do gel de agarose contendo (1) o RNA total extraído da SK-BR-3, (2) o cDNA obtido da RT-PCR desse material, (3) o produto da PCR do cDNA, e (4) o produto da PCR com condições de ciclagem alteradas. (B) Negativo da foto do mRNA obtido pela transcrição in vitro do produto da PCR modificada.

As condições de amplificação da PCR foram então alteradas, aumentando-se a temperatura de anelamento e o tempo de extensão. O DNA obtido por esse método não apresentou a banda de 200 pb, como ocorria anteriormente, e sim uma grande 
quantidade de bandas mais fracas, com tamanho superior a $400 \mathrm{bp}$ (Figura 45A). $\mathrm{O}$ padrão do RNA transcrito com o produto dessa PCR, porém, não apresentou tais bandas (Figura 45B).

Para testar se a alteração na PCR foi suficiente para gerar um RNA amplificado íntegro, o processo foi realizado com mRNA para GFP. Com as novas condições, o produto da PCR mostrou ser composto majoritariamente por uma banda do mesmo tamanho da banda encontrada no cDNA do GFP (Figura 46). Porém, após a etapa de transcrição in vitro, não havia nenhuma banda definida no gel, sendo este RNA amplificado incapaz de gerar expressão de GFP quando transfectado em células da linhagem MDA-MB-231 (dados não mostrados).

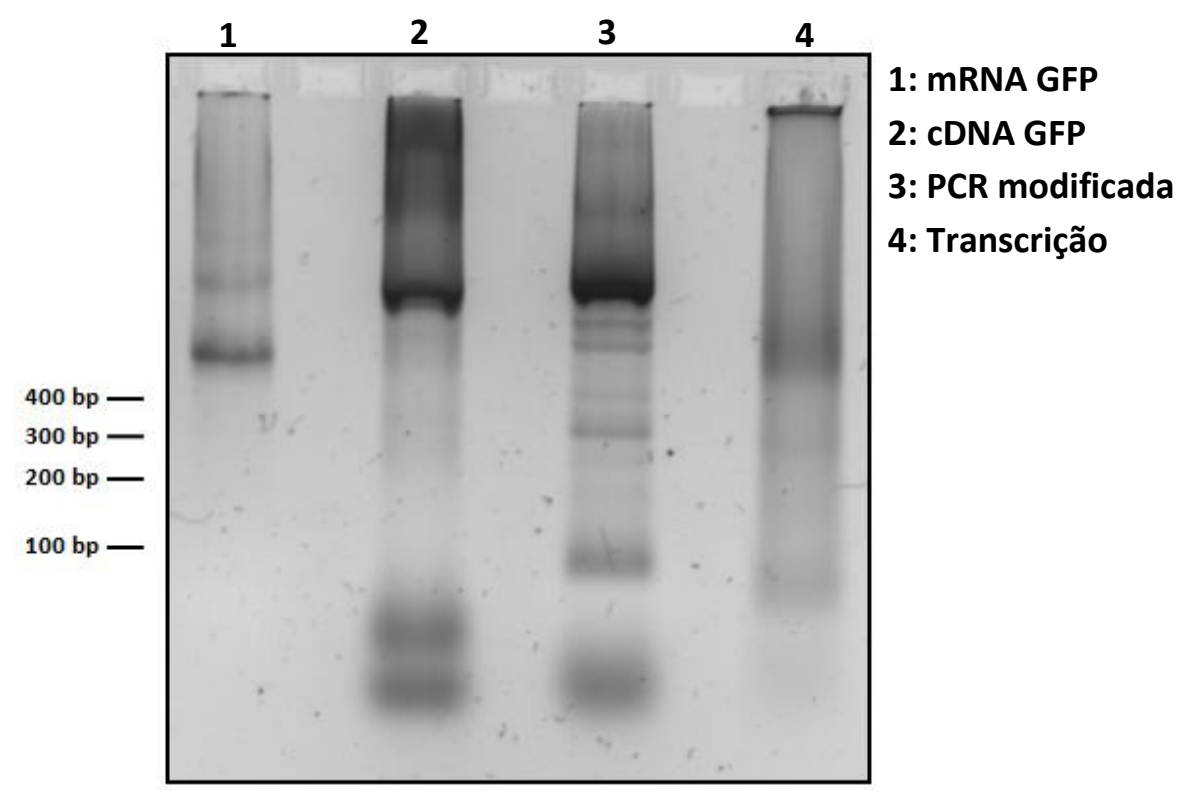

Figura 46 - Produto da PCR do mRNA para GFP com condições da PCR amplificação alteradas. Negativo da foto do gel de agarose contendo (1) o mRNA para GFP, (2) o cDNA obtido da RT-PCR desse material, (3) o produto da PCR do cDNA com as condições de ciclagem alteradas e (4) o produto da transcrição da PCR.

Sendo assim, optou-se por fazer a reação de transcrição in vitro utilizando-se um kit comercial, uma vez que nenhuma das alterações de protocolo testada para transcrição foi suficiente para gerar um material íntegro. O mRNA para GFP obtido pela transcrição com kit do produto da PCR modificada mostrou-se mais íntegro, com uma banda forte com o mesmo tamanho do mRNA para GFP (Figura 47A). Como as bandas do cDNA e da PCR estavam em uma localização diferente da banda do mRNA, correu- 
se um gel de agarose desnaturante, para verificar se essa diferença era simplesmente devido à estrutura secundária do RNA ou se era devido a um tamanho diferente do produto de cada banda. Apesar de fraca, a marcação no gel desnaturante mostrou que a diferença em tamanho observada era simplesmente devido a estruturas secundárias, e que, portanto, o processo de amplificação, com todas as modificações feitas, foi capaz de gerar um transcrito aparentemente íntegro (Figura 47B).

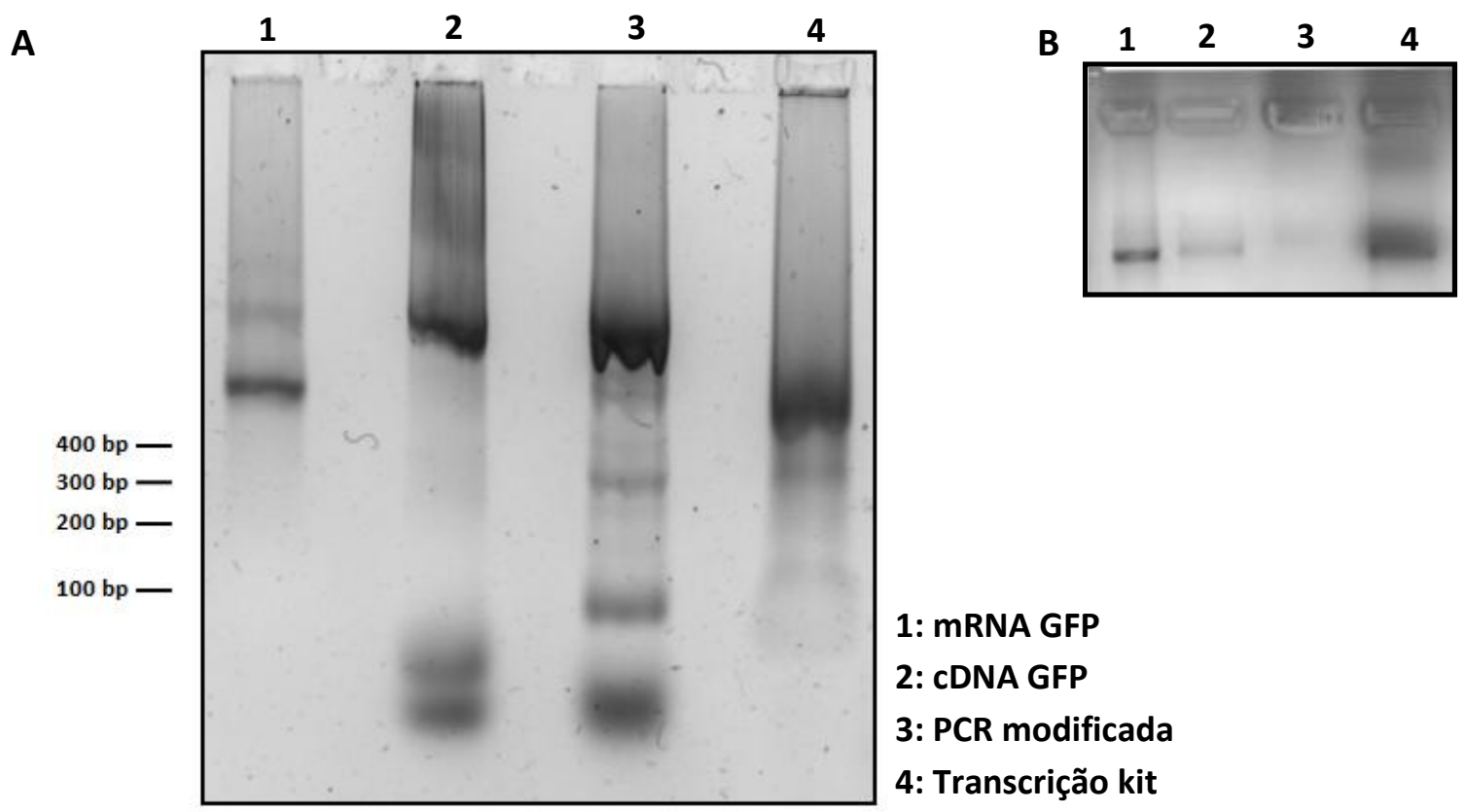

Figura 47 - Produto da amplificação do mRNA para GFP utilizando condições da PCR alteradas e kit de transcrição. Negativo da foto do gel de agarose (A) não desnaturante ou (B) desnaturante. Os géis contêm: (1) o mRNA para GFP, (2) o cDNA obtido da RT-PCR desse material, (3) o produto da PCR do CDNA com as condições de ciclagem alteradas e (4) o produto da transcrição da PCR utilizando kit comercial.

Para testar a integridade do mRNA para GFP amplificado, esse foi transfectado em células da linhagem MDA-MB-231 após ser ou não purificado por precipitação com $\mathrm{LiCl}$. Parte das células transfectadas com esse material ficou verde, sendo a porcentagem de células positivas maior quando o mRNA amplificado foi purificado (Figura 48). Isso mostra que é possível amplificar um mRNA de modo que ele continue íntegro e sendo capaz de ser traduzido, gerando a proteína que este codifica. 

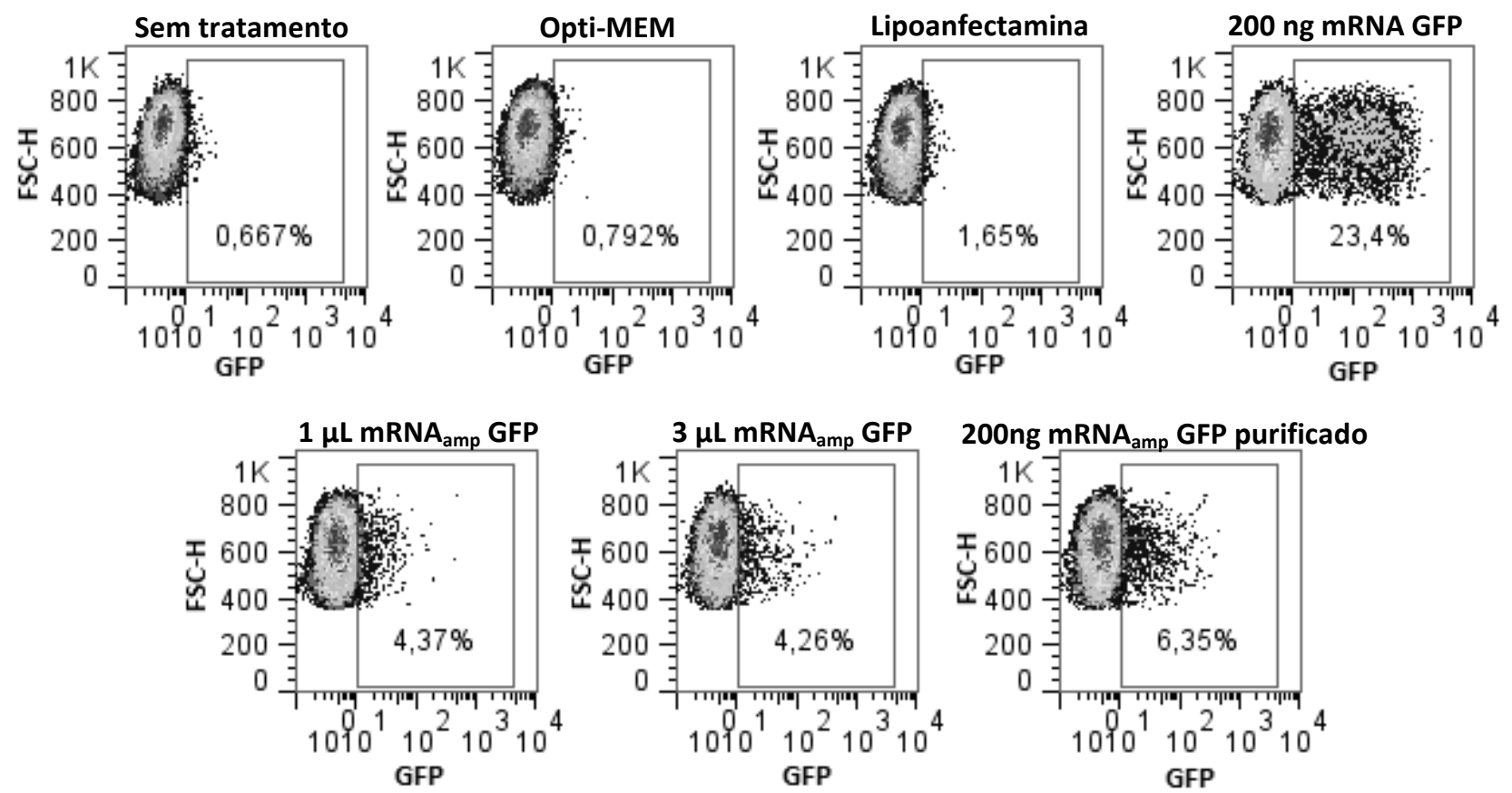

Figura 48 - Expressão de GFP nas células transfectadas com mRNA para GFP amplificado. Gráficos da expressão de GFP em células da linhagem MDA-MB-231 não tradadas, tratadas apenas com o veículo Opti-MEM ou o agente de transfecção lipoanfectamina, ou transfectada com o mRNA GFP amplificado (mRNA $A_{a m p}$ GFP) ou não.

O próximo passo foi, então, fazer o mesmo processo com o RNA total de células tumorais. Dessa vez, o produto da transcrição se mostrou similar ao produto da PCR, ambos sem apresentarem a banda de 200 pb que era encontrada antes das alterações do protocolo (Figura 49). Tanto o cDNA quando o produto da PCR obtidos do RNA total por esse novo protocolo apresentaram quantidades variáveis de diversas moléculas (Figura 50). Como esperado, o cDNA da SK-BR-3 apresentou muito mais moléculas que codificam Her2/neu do que o cDNA da MDA-MB-231. A amplificação pela PCR foi capaz de aumentar a quantidade de cDNA para Her2 nas duas linhagens. Por outro lado, a expressão de $\beta_{2}$-microglobulina diminuiu após a PCR, nas das linhagens. Poucas cópias específicas para HLA-A e HLA-DR foram encontradas na SK-BR-3, que não expressa tais moléculas em sua superfície, mas essa quantidade foi, também, ligeiramente aumentada após a PCR. A quantidade de HLA-A e HLA-DR aumentou também no material da linhagem MDA-MB-231. Sendo assim, foi possível perceber que o processo de amplificação é capaz de enriquecer certos mRNAs de antígenos em detrimento de 
outros, mas sem diminuir a quantidade a ponto de que essa não fosse detectada na qPCR.

A

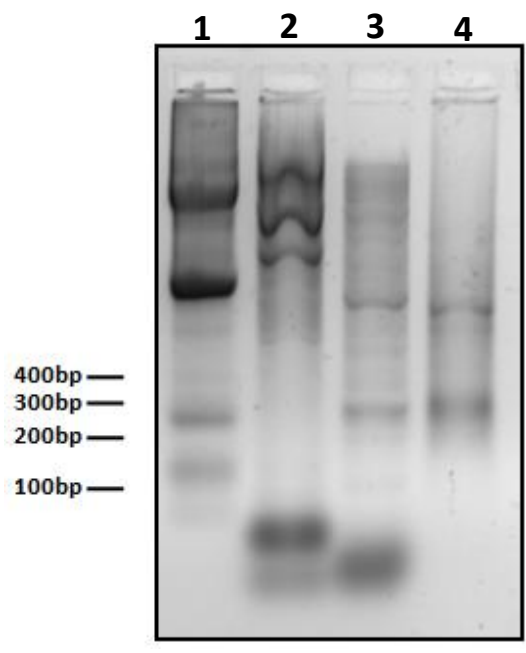

B

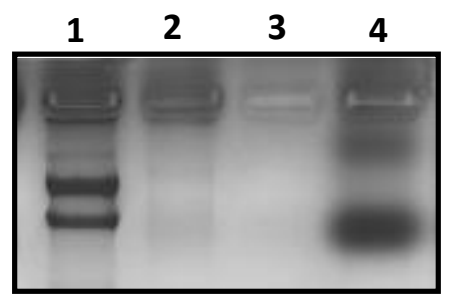

1: RNA total SK-BR-3

2: CDNA

3: PCR modificada

4: Transcrição kit

Figura 49 - Produto da amplificação do mRNA da SK-BR-3 utilizando condições

da PCR alteradas e kit de transcrição. Negativo da foto do gel de agarose $(A)$ não desnaturante ou (B) desnaturante. O gel contém: (1) o RNA total da SK-BR-3, (2) o cDNA obtido da RT-PCR desse material, (3) o produto da PCR do cDNA com as condições de ciclagem alteradas e (4) o produto da transcrição da PCR utilizando kit comercial.
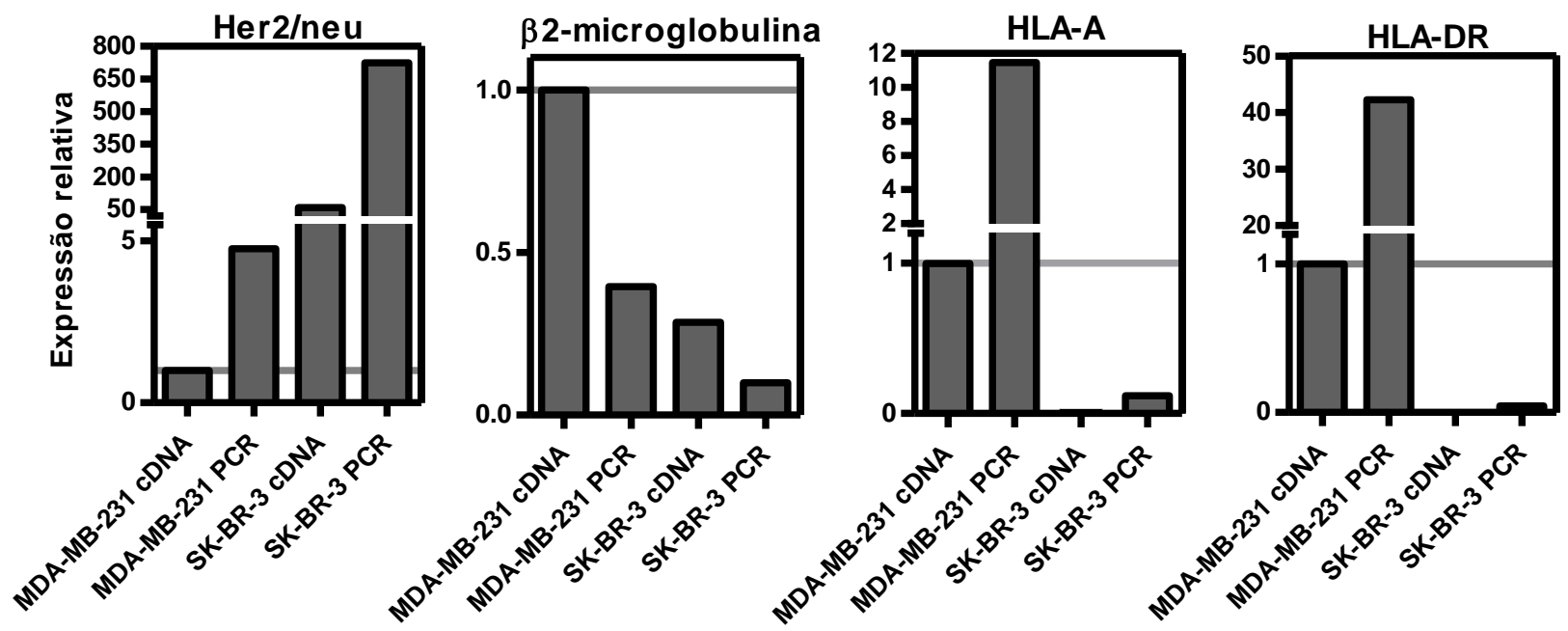

Figura 50 - Expressão de moléculas antes e após amplificação do RNA tumoral.

Expressão relativa ao gene da $\beta$-actina, medida por real time PCR, de diferentes moléculas no produto do cDNA e da PCR do RNA das linhagens tumorais de mama MDA-MB-231 e SK-BR-3. 
Ao ser transfectado em células tumorais, porém, o mRNA amplificado não gerou aumento de expressão de nenhuma das moléculas testadas. O mRNA amplificado de células verdes também não gerou expressão detectável de GFP (dados não mostrados). Ambos os fenômenos não excluem a possibilidade das moléculas estarem sendo traduzidas e apresentadas como antígenos, mas atentam para o fato de que outras modificações no protocolo de amplificação podem melhorar a qualidade do mRNA amplificado obtido. 
No presente estudo, células dendríticas maduras (mDCs), com fenótipo adequado, foram geradas a partir da diferenciação in vitro de monócitos do sangue periférico de doadores saudáveis. Essas células foram utilizadas para formação de híbridos com células tumorais, sendo a eficiência do processo avaliada, assim como o fenótipo e capacidade estimuladora dos híbridos obtidos. Avaliou-se, também, a capacidade dos híbridos de estimular uma resposta imune antígeno-específica. Por último, avaliaram-se as condições de amplificação in vitro do RNA proveniente de células tumorais e da transfecção desse RNA, amplificado ou não, em células de linhagens tumorais receptoras.

Linhagens tumorais com diferentes fenótipos foram utilizadas nesse trabalho (Figuras 9). É sabido que, como mecanismo de escape tumoral, células tumorais costumam perder a expressão de moléculas de classe I do MHC, da $\beta_{2}$-microglobulina ou dos componentes da maquinaria de processamento de antígenos, impedindo seu reconhecimento por linfócitos $T$ citotóxicos (CTLs) (SELIGER, 2008). A ausência de moléculas de classe I do MHC (HLA-ABC) em células de câncer de mama está associada com um pior prognóstico desses tumores (KANEKO, ISHIGAMI, et al., 2011). Com consequências semelhantes, a superexpressão de Her2/neu é capaz de diminuir a expressão de diversas proteínas responsáveis pelo processamento de antígenos (HERRMANN, LEHR, et al., 2004). Interessantemente, dentre as linhagens de câncer de mama analisadas, a única cuja expressão de HLA-ABC não foi detectada foi a linhagem SK-BR-3, que também foi a única a apresentar superexpressão de Her2/neu. A perda de expressão das moléculas de classe I do $\mathrm{MHC}$ nessas células, porém, não foi devido à perda do mRNA para $\beta_{2}$-microglobulina, uma vez que este foi detectado no RNA total extraído dessas células (Figura 38). A ausência de moléculas de classe I do MHC nessas células pode ter sido devida a uma baixa quantidade do mRNA dessas moléculas, uma vez que poucas cópias do mRNA para HLA-A foi encontrada no preparado de mRNA total da SK-BR-3 (Figura 50).

Duas das cinco linhagens que tiveram seu fenótipo avaliado apresentaram expressão de HLA-DR. A expressão de moléculas de MHC de classe II por células tumorais é conhecida como outro mecanismo de escape tumoral (THIBODEAU, BOURGEOIS-DAIGNEAULT, LAPOINTE, 2012). Uma vez que as células tumorais não 
expressam moléculas co-estimuladoras, a presença de moléculas do MHC de classe II faz com que essas células consigam induzir anergia em linfócitos $\mathrm{T} \mathrm{CD}^{+}$que reconheçam algum antígeno tumoral que elas estejam apresentando.

Estudos também foram feitos avaliando a diferenciação de monócitos obtidos do sangue periférico de doadores saudáveis, em células dendríticas maduras (mDCs). De modo geral, as mDCs geradas apresentaram o fenótipo esperado, diminuindo a expressão de CD14, e mantendo a expressão de HLA-DR, além de expressarem diversas moléculas co-estimuladoras, como CD80, CD86, CD83 e CD40 (Figura 8). Intrigantemente, a porcentagem de células positivas para CCR7 se manteve alta durante toda a diferenciação, mas a quantidade de moléculas na superfície das células teve uma tendência de queda após a maturação das iDCs. Um estudo da expressão de CCR7 em DCs diferenciadas de monócitos mostrou a importância da presença da prostaglandina E2 durante a maturação dessas células para que haja a expressão desse receptor (SCANDELLA, MEN, et al., 2002). Sendo assim, a queda de CCR7 observada nas mDCs pode ter sido devido à ausência, nesse estudo, de prostaglandina E2 no estimulo de ativação utilizado para as iDCs, que consistiu apenas de TNF- $\alpha$. Com relação às subpopulações de células dendríticas, é possível caracterizar as DCs geradas como células dendríticas mielóides, uma vez que, em sua maioria, expressam CD11c e não expressam CD123.

Em seguida, as células dendríticas geradas por esse processo de diferenciação foram fundidas com células da linhagem MDA-MB-231. Essa linhagem foi a escolhida por ser a que mais expressou moléculas do MHC de classe I, e, portanto, potencialmente a mais imunogênica entre as linhagens. A metodologia de utilização de corantes celulares viáveis para determinar a eficiência da fusão foi deixada de lado após constatação da presença de uma população duplo-positivae no grupo onde as células foram apenas misturadas (Figuras 10 e 12). A presença de células duplo-positivas para os corantes na mistura mostrou ser devido à marcação das células tumorais com o corante usado nas DCs, sendo essa marcação dependente do tempo que essas células eram deixadas interagindo (Figura 11). Recentemente, estudos do nosso laboratório mostraram que células tumorais são capazes de incorporar exossomos provenientes de DCs, o que 
poderia explicar a incorporação da marcação do corante utilizado nas células dendríticas, pelas células tumorais (ROMAGNOLI, TONIOLO, et al., 2013).

Com a utilização de marcadores de membrana, foi possível detectar em torno de $15 \%$ de células híbridas geradas a partir da fusão de células dendríticas e células tumorais por meio do processo de eletroporação (Figuras 13 e 14). Optou-se por fazer a fusão utilizando células dendríticas maduras, uma vez que a quantidade de híbridos obtidos era maior usando mDCs quando comparado com o uso de iDCs (Figura 15). Além disso, os híbridos de mDCs mostraram maior quantidade de moléculas de HLA-DR, sendo, portanto, melhores apresentadores de antígeno (Figura 16).

Com relação ao fenótipo das células eletroporadas, foi possível observar um aumento de diversos marcadores mesmo nas células que não eram duplo-positivas no grupo da fusão (Figura 17). De fato, a eletroporação de cada tipo celular separadamente também foi capaz de aumentar a expressão de diversos marcadores (dados não mostrados). Já foi demonstrado que DCs podem aumentar a expressão de diversas moléculas de co-estímulo ao serem eletroporadas (CHUNG, ROMANO, et al., 2013). Porém, deve-se levar em conta que, uma vez que a eletroporação compromete a integridade de membrana das células, a marcação observada pode ser devido à marcação inespecífica de sítios intracelulares, ou à marcação de moléculas que se encontram no citoplasma em um estado inativo. A molécula CD83, por exemplo, encontra-se pré-formada em compartimentos intracelulares das células dendríticas imaturas, sendo expressas na membrana apenas após o estímulo de ativação (CAO, LEE, LU, 2005).

Foi possível observar um aumento na quantidade de moléculas de classe I do MHC no grupo de células eletroporadas (Figura 18). Para avaliar se essa expressão era devido à co-expressão de moléculas provenientes das duas células, cada tipo celular foi marcado antes da eletroporação com um anticorpo para HLA-ABC conjugado com um fluorocromo diferente. Esse protocolo também minimiza o possível efeito inespecífico da marcação de sítios intracelulares dentro das células eletroporadas, uma vez que as mesmas são marcadas antes da eletroporação e o excesso de anticorpo é lavado antes do ensaio. Nessas condições, foi possível observar que as células duplo-positivas para Her2/neu e CD11c eram, em sua maioria, positivas para os dois anticorpos de HLA-ABC, 
mostrando que os híbridos gerados expressam moléculas de classe I do MHC provenientes dos dois tipos celulares. Sendo assim, os híbridos semi-alogeneicos seriam capazes de apresentar antígenos tanto num contexto alogeneico proveniente das moléculas de MHC das DCs, quanto em um contexto autólogo das células tumorais.

Como as células híbridas apresentaram um fenótipo estimulador, resolveu-se avaliar a capacidade dessas células de estimular linfócitos T. Para isso, houve a necessidade de se testar o efeito da irradiação nas células estimuladoras, uma vez que esta é essencial parar o crescimento das células tumorais durante a co-cultura, para evitar que estas consumam todo o meio disponível. Foi descrito que pequenas doses de irradiação gama são capazes de alterar o fenótipo das células dendríticas, sua capacidade de induzir proliferação de linfócitos $T$ e sua produção de citocinas em co-cultura com linfócitos (CAO, CHEN, XING, 2004; REUBEN, KORBLING, et al., 2004). Porém, a dose de irradiação utilizada no presente trabalho foi muito maior do que as doses utilizadas nesses estudos. Sendo assim, avaliou-se o efeito da dose de irradiação de 200 Gy sobre os híbridos de células dendríticas e células tumorais. De modo geral, as células tumorais parecem ter parado de proliferar após receberem tal dose de irradiação (Figura 19). Embora não tenha sido possível encontrar alterações fenotípicas significativas nas células que foram irradiadas, houve uma discreta diminuição da porcentagem de células híbridas após a irradiação (Figura 20). Apesar das células irradiadas terem induzido menor proliferação em dois dos três experimentos realizados, as diferenças encontradas não foram estatisticamente significativas entre as células irradiadas e não irradiadas (Figura 21). Por outro lado, a irradiação, de fato, alterou o perfil de citocinas produzidas durante a co-cultura das células irradiadas com linfócitos $T$, assim como descrito por Cao et al. para pequenas doses de irradiação gama (Figura 22). Em suma, estas observações mostram que, embora ocorram alterações nas células híbridas irradiadas, estas foram discretas e menores do que as descritas na literatura; com isso, manteve-se a dose de irradiação, uma vez que essa é a utilizada em protocolos clínicos de aplicação das células híbridas.

Uma vez que os híbridos de células dendríticas e células tumorais foram capazes de induzir a proliferação de linfócitos $T$ (Figura 21), questionou-se sobre o tipo de resposta que esses híbridos seriam capazes de induzir. Este ponto foi, portanto, 
inicialmente abordado em um ensaio de sensibilização em macroculturas. Foi possível observar a formação de pequenas colônias na cultura, indicando uma provável proliferação clonal de linfócitos T (Figura 23).

Com relação ao fenótipo dos linfócitos $T$, foi possível observar uma queda de CD62L após a segunda estimulação mesmo no grupo de linfócitos $T$ tratados apenas com citocinas. O CD62L é a molécula responsável por direcionar os linfócitos T para os linfonodos. Sendo assim, sua queda indica que, em todos os grupos, parte dos linfócitos se tornaram células efetoras, não mais sendo direcionadas para o linfonodo. As mudanças observadas no padrão de expressão das isoformas de CD45 também corroboram tal hipótese.

O padrão de expressão de CD69, porém, foi distinto entre os grupos tratados com MIX e fusão, que apresentaram positividade apenas após o segundo estímulo, e o grupo sem tratamento, que apresentou positividade apenas após o primeiro estímulo (Figura 24). A molécula CD69 é rapidamente induzida após estimulação, atingindo seu pico em apenas poucas horas após o estímulo (SIMMS, ELLIS, 1996). Sendo assim, aparentemente a ativação dos linfócitos apenas com citocinas ocorre após a primeira estimulação, enquanto o MIX e a fusão parecem induzir uma ativação maior após o segundo estímulo.

O padrão de citocinas obtido no sobrenadante da cultura indicou uma possível polarização para o padrão Th1 (Figura 25). A análise da expressão dos fatores de transcrição nos linfócitos, porém, não revelou uma polarização preferencial para nenhum padrão específico (Figura 26). Por outro lado, foi possível observar uma diferença na porcentagem de células Foxp3 positivas, que foi menor no grupo estimulado com a fusão. Esses dados indicam que os híbridos são capazes de estimular a diferenciação de linfócitos $\mathrm{T} \mathrm{CD4}^{+}$, ao mesmo tempo em que parecem ser menos eficientes na estimulação de linfócitos $T$ com perfil regulatório do que a mistura de DCs e células tumorais.

Para avaliar a capacidade de indução CTLs pela fusão, avaliou-se a capacidade dos linfócitos sensibilizados de induzir morte celular das células de diferentes linhagens de câncer de mama (Figura 27). Os linfócitos T tratados apenas com as citocinas IL-7 e IL-2 induziram citotoxicidade principalmente nas células da linhagem MDA-MB-231, que 
se mostrou mais suscetível pela morte induzida pelos linfócitos $\mathrm{T}$ do que as outras linhagens. Sabe-se da literatura que apenas a adição de IL-2 na cultura é suficiente para gerar linfócitos $T$ com capacidade de matar células tumorais, ou seja, células com fenótipo denominado LAK (lymphokine-activated killer) (GRIMM, ROBB, et al., 1983). Portanto, não é surpreendente que os linfócitos T sem contato com MIX ou fusão tenham apresentado capacidade citotóxica, mesmo tendo-se tomado o cuidado de utilizar baixas doses de IL-2 na cultura. Por outro lado, foi possível observar uma indução de linfócitos T específicos para as células tumorais, uma vez que os grupos estimulados com o MIX e a fusão induziram uma maior citotoxicidade do que a observada no grupo de linfócitos estimulado apenas com as citocinas.

Logo, um experimento foi feito visando avaliar com mais cuidado se as células híbridas eram capazes de gerar uma resposta específica. Nesse experimento, todos os grupos induziram expansão de linfócitos $T$ (Figura 29). Em condições normais, os linfócitos $T$ são capazes de sofrer proliferação homeostática na presença de apenas antígenos próprios e citocinas IL-7 e IL-15 (TAN, DUDL, et al., 2001). Essas citocinas, em conjunto com a IL-2, foram utilizadas durante todo protocolo de sensibilização, de modo que não é surpreendente que tenha havido proliferação em todos os grupos, mesmo na ausência de antígenos não-próprios. Sendo assim, o próximo passo foi analisar quais grupos foram capazes de induzir uma expansão clonal de linfócitos $T$ específicos para o antígeno de interesse. Apenas os grupos que continham o antígeno foram capazes de induzir tal expansão, mas ambas mistura e fusão induziram quantidades similares de linfócitos T reativos ao tetrâmero de HLA-A2 (Figura 30). Além disso, os híbridos foram capazes de processar e apresentar novamente os antígenos tumorais, após a eletroporação, uma vez que induziram expansão de linfócitos T restritos a um tipo de HLA que não estava presente na célula tumoral. A apresentação de novo de antígenos por células híbridas vem sendo alvo de pesquisas recentes (KOIDO, GONG, 2013). Aqui mostramos, porém, um relato direto de que realmente os híbridos gerados por eletroporação são capazes de apresentar um antígeno tumoral no contexto das moléculas de MHC provenientes das DCs.

Como ambas, mistura e fusão, foram capazes de expandir linfócitos T específicos, avaliou-se, então, se esses linfócitos eram funcionais. Os linfócitos estimulados tanto 
pela mistura quanto pela fusão foram igualmente reativos à mistura de peptídeos, mas apenas os linfócitos estimulados pela fusão foram capazes de reagir especificamente contra as células contendo o antígeno (Figura 31 e 32). Em modelo murino, já foi mostrado que os híbridos de DCs e células tumorais são capazes de gerar linfócitos $T$ citotóxicos que diminuem a massa tumoral existente no camundongo (GONG, CHEN, et al., 1997), mostrando novamente que os linfócitos $T$ estimulados pelos híbridos são capazes de exercer uma função efetora.

Em seguida, dado que as células híbridas foram capazes de gerar uma resposta específica, avaliou-se a capacidade de enriquecer uma célula com antígenos de outra através da transferência de RNA. Para isso, o RNA total extraído das células da linhagem SK-BR-3 foi misturado com mRNA para GFP, que foi utilizado como repórter, e transfectado em células das linhagens MDA-MB-231 e MCF-7. A transfecção de linhagens tumorais de mama com mRNAs acoplados a lipossomas catiônicos não é uma ideia nova, mas necessita de extensa padronização, uma vez que resultados muito diferentes são encontrados com preparações lipídicas distintas (LU, BENJAMIN, et al., 1994). De fato, a transfecção com quatro diferentes agentes lipídicos comerciais resultou em diferentes porcentagens de células positivas para GFP (Figura 33). O agente de transfecção que se mostrou mais eficiente nesse teste foi o utilizado para os ensaios posteriores.

Os esforços foram, então, direcionados para a procura de proteínas presentes no RNA total que aumentassem após a transfecção, e que, portanto, pudesse ser utilizada para avaliar a eficiência da transfecção. Apesar da quantidade de mRNA para HLA-DR ter aumentado após a transfecção da linhagem MCF-7 (Figura 34), não foi possível observar aumento dessa proteína na membrana celular (dados não mostrados). $\mathrm{O}$ mesmo fenômeno foi observado para a molécula Her2/neu que, apesar de ser superexpressa na SK-BR-3 e ter seu mRNA presente no RNA total dessa linhagem, não teve sua expressão aumentada quando as células das linhagens MDA-MB-231 e MCF-7 foram transfectadas com o RNA total da SK-BR-3. Benz et al mostraram que é possível induzir superexpressão de Her2/neu em células da linhagem MCF-7 transfectando-as com o cDNA dessa molécula. Porém, o aumento da expressão de Her2/neu foi observado em apenas 7 de 36 subclones (BENZ, SCOTT, et al., 1992). 
As únicas proteínas que, de fato, tiveram sua expressão aumentada na superfície das células transfectadas com RNA total, foram as moléculas de classe I do MHC. Esse aumento, porém, foi observado apenas nas células linhagem MCF-7 (Figura 35), e mesmo quando essas células foram transfectadas apenas com mRNA para GFP (Figura 36). Sabe-se que a expressão de moléculas de classe I do MHC pode ser aumentada quando uma célula sofre infecção por vírus, por meio da produção de interferon do tipo I (IFN- $\alpha$ e IFN- $\beta$ ) induzida pelo reconhecimento de RNA de dupla fita de origem viral (BIRON, 2001). A transfecção de RNA de fita simples de origem viral também é capaz de aumentar a expressão de moléculas de classe I do MHC (SUZUKI, YANAGI, et al., 2002). O aumento de HLA-ABC observado nas células da linhagem MCF-7 parece ser devido ao processo de transfecção em si, e não à presença dessas proteínas no RNA transfectado. De fato, mecanismo similar foi descrito em células de linhagens tumorais transfectadas com DNA, mesmo na ausência de sequências específicas para as moléculas de classe I do MHC (FOX, DRURY, et al., 1998).

Sendo assim, como não foi possível encontrar uma proteína que tivesse sua expressão aumentada devido ao aumento de seu mRNA no interior da célula, um experimento foi feito para verificar se os mRNAs realmente podiam ser traduzidos e expressos na célula receptora. Para isso, células da linhagem MDA-MB-231 transfectadas com mRNA para GFP tiveram seu RNA total extraído e transfectado em novas células da linhagem MDA-MB-231. Parte das células que receberam esse RNA foram capazes de expressar essa proteína, mostrando que os RNAs são capazes de ser traduzidos na célula receptora (Figura 37). De fato, a transfecção de RNAs tumorais em células dendríticas já foi reportada como sendo capaz de fazer com que as DCs expressem antígenos tumorais (GRÜNEBACH, MÜLLER, et al., 2003; NENCIONI, MÜLLER, et al., 2003). Porém, a literatura carece de ensaios de transferência de RNA em células tumorais, sendo observada a expressão proteica apenas em casos de transdução viral com DNA contendo proteínas de interesse (ANTONIA, SEIGNE, et al., 2002).

O próximo passo do trabalho foi avaliar o processo de amplificação e transcrição in vitro de mRNAs. Foi possível observar um alto potencial de amplificação desse processo, uma vez que, com os dados obtidos da amplificação, calcula-se que seria 
possível obter 10.000 vezes a quantidade inicial de RNA caso o processo fosse feito com todo o RNA disponível. Com relação ao tamanho dos fragmentos amplificados, observouse um viés para amplificação de fragmentos pequenos. O tamanho médio do mRNA de células Hela, uma linhagem de células tumorais humanas, é de aproximadamente 1.400 $\mathrm{pb}$, estando, em sua maioria, distribuídos próximo da banda correspondente ao rRNA 18S, que tem tamanho de 1.900 pb em humanos (SOMMER, COHEN, 1980). Porém, foi possível observar que a PCR amplificou, em sua maioria, sequências pequenas de cDNA, apresentando uma banda forte por volta de 200 pb (Figura 38). Esse efeito pode ter sido devido ao fato de que, em uma reação de PCR complexa, ou seja, que amplifica fragmentos de tamanhos muito distintos, existe uma amplificação mais eficiente de fragmentos menores, que acabam aumentando sua representatividade após a reação (SHAGIN, LUKYANOV, et al., 1999). Isso pode fazer com que alguns mRNAs específicos, que estavam presentes na amostra inicial, não estejam presentes na mesma concentração após o processo, ou até mesmo estejam ausentes.

Após o processo de transcrição, foi possível observar um rastro de material genético compreendendo desde moléculas pequenas, até moléculas com tamanhos superiores a 5.000 bp (tamanho correspondente à banda $28 \mathrm{~S}$ em humanos). Logo, apesar do padrão da PCR, quantidades significativas de mRNAs longos apareceram após o processo de transcrição in vitro. Porém, ainda assim foi possível verificar a perda de mRNAs específicos para algumas moléculas após a amplificação (Figura 39).

Em seguida, o mRNA amplificado do RNA total da SK-BR-3 foi transfectado em células da linhagem MCF-7 e MDA-MB-231. Foi observado uma grande toxicidade nos grupos tratados com o mRNA amplificado e nenhuma expressão de GFP foi observada (Figuras 40 e 41). A modificação das condições de transfecção, incluindo o uso de uma quantidade muito pequena de mRNA, não foi capaz de diminuir a citotoxicidade observada nas células. Alguns protocolos de transfecção de DCs com mRNA amplificado obtido de células tumorais incluem um passo de retirada das proteínas utilizadas no processo de amplificação (BOCZKOWSKI, NAIR, et al., 2000). Porém, mesmo retirando as proteínas por um processo de extração com trizol, não foi possível observar melhora na eficiência da transfecção do mRNA amplificado. 
Dado que, após o processo de amplificação, houve uma mudança no tamanho médio dos ácidos nucleicos, foi avaliado se a citotoxicidade observada na transfecção era devido a alguma das frações de tamanho do mRNA amplificado. De fato, a transfecção da fração contendo os menores fragmentos reproduziu os efeitos encontrados com a transfecção do mRNA amplificado, enquanto observou-se expressão de GFP e menor citotoxicidade quando as células foram transfectadas apenas com os maiores fragmentos do mRNA amplificado (Figura 43). Intrigantemente, ao separar as frações antes da amplificação por PCR, observou-se a formação da banda de $200 \mathrm{~kb}$ nas três frações após a PCR, e os três fragmentos gerados por esse protocolo foram citotóxicos para as células transfectadas. Esses pequenos fragmentos são, portanto, o provável causador dos efeitos indesejáveis da transfecção do mRNA amplificado descritas nesse trabalho.

A presença de fragmentos pequenos após a PCR, mesmo quando o produto inicial foi separado de modo a conter apenas fragmentos grandes, mostra que, provavelmente, algum outro efeito está acontecendo durante a PCR, além da provável amplificação preferencial de fragmentos pequenos. Uma possível causa do aparecimento desses fragmentos pode ser devido à baixa processividade (50 a 80 nucleotídeos) da enzima Taq polimerase, utilizada nesse protocolo (MERKENS, BRYAN, MOSES, 1995). A processividade é a capacidade da DNA polimerase de copiar um template de DNA sem se dissociar do mesmo, sendo o número relacionado à quantidade de nucleotídeos que são colocados a cada ligação da enzima ao template (ZHUANG, Al, 2010). Sendo assim, é possível que, durante o processo de amplificação, o cDNA não consiga ser copiado até o final, devido a quantidade de vezes que a enzima precisa se associar à fita, formando assim os pequenos fragmentos observados. Uma observação que corrobora essa hipótese é a formação da mesma banda de 200 pb na amplificação apenas do mRNA para GFP (Figura 44). Esse RNA amplificado não foi capaz de gerar expressão de GFP nas células, mostrando que sua integridade foi comprometida durante o processo.

Sendo assim, alterações foram feitas na ciclagem da PCR, de modo a diminuir a quantidade de fragmentos não íntegros. Essas modificações foram, de fato, capazes de melhorar o produto de PCR, de modo que este apresentou bandas maiores e ausência da banda de $200 \mathrm{pb}$ tanto utilizando RNA total, quanto utilizando apenas o RNA para 
GFP como template (Figura 45 e 46). Porém, apenas ao se modificar também o processo de transcrição in vitro, foi possível obter um mRNA para GFP amplificado que apresentou apenas uma banda em gel de agarose e foi capaz de, quando transfectado, gerar células que expressavam GFP (Figuras 47 e 48).

Por último, mRNAs das células tumorais foram amplificados com o protocolo alterado. O produto da amplificação apresentou um padrão em gel de agarose bem diferente do encontrado anteriormente (Figura 49). Além disso, uma análise da composição do RNA amplificado mostrou a presença de mRNAs para diversas proteínas, tendo, alguns deles, aumentado e outros diminuído a representatividade após amplificação (Figura 50). A mudança na composição do mRNA, após amplificação, é esperada, já tendo sido descrito na literatura tanto aumento (no caso do antígeno PSA) quanto diminuição (no caso de $\beta$-actina) de mRNAs específicos, após amplificação, em duas diferentes situações (BOCZKOWSKI, NAIR, et al., 2000; HEISER, MAURICE, et al., 2001).

O mRNA amplificado por esse protocolo, porém, não foi capaz de aumentar a expressão das moléculas testadas, quando transfectado em células tumorais. Esses resultados não excluem a possibilidade de que parte desse material pode estar sendo traduzido e apresentado como antígeno. A maioria dos artigos publicados na literatura não mostra a presença da proteína após transfecção, e sim apenas a resposta de linfócitos $T$ citotóxicos induzida pelas DCs transfectadas (BERGANT, MEDEN, et al., 2006; NI, RICHMOND, et al., 2008). Apesar disso, tais resultados mostram que, talvez, novas modificações no protocolo de amplificação sejam necessárias para melhorar a qualidade do mRNA obtido.

Portanto, os resultados aqui apresentados mostram que as células dendríticas diferenciadas in vitro podem ser fundidas com células tumorais por um processo de eletroporação, gerando híbridos que são capazes de estimular uma resposta imune antitumoral antígeno-específica. Por outro lado, é possível amplificar o mRNA presente em células tumorais e transfectar esse produto em células de linhagens tumorais, apesar de ajustes nesses protocolos ainda serem necessários. 


\section{CONCLUSÃO}


Os resultados obtidos nesse trabalho indicam que:

- Híbridos de células dendríticas e células tumorais expressam moléculas de classe I do MHC provenientes das duas células, além de moléculas de co-estímulo, sendo, portanto, potencialmente capazes de apresentar antígenos tumorais em um contexto imunogênico.

- Linfócitos T podem ser estimulados por híbridos de células dendríticas e células tumorais a se diferenciarem e proliferarem e, aparentemente, os linfócitos $T$ assim estimulados apresentam menor expressão de Foxp3 do que os estimulados apenas com a mistura dos dois tipos celulares.

- Híbridos de células dendríticas e células tumorais são capazes de induzir uma resposta imune antígeno-específica, ou seja, induzir uma expansão clonal linfocitária de linfócitos capazes de responder contra o antígeno.

- Híbridos de células dendríticas e células tumorais parecem continuar sendo capazes de processar e apresentar novos antígenos após o processo de eletroporação.

- RNA total de uma célula pode ser transfectado em outra, levando ao aumento da quantidade de mRNA específico para algumas moléculas e podendo levar a expressão de novas moléculas pela célula transfectada.

- Um mRNA pode ser amplificado por um processo complexo, gerando novas moléculas de mRNAs íntegras que podem ser traduzidas e gerar, quando transfectadas em uma célula, a proteína que este mRNA codifica.

- Uma amostra complexa com diferentes mRNAs também pode ser amplificada, mas diferenças na quantidade de cada mRNA podem ser observada após a amplificação. 
- O processo de amplificação de mRNA total obtido de células tumorais precisa ser aperfeiçoado, uma vez que não se observou expressão de proteínas contidas na amostra amplificada, quando esta foi transfectada em outras células.

Sendo assim, conclui-se que a metodologia proposta por esse trabalho é uma estratégia promissora, que merece ser explorada, mas que ainda necessita aperfeiçoamento para que se consiga expressão suficiente de antígenos codificados pelo mRNA extraído das células tumorais dos pacientes nas células híbridas dendriticastumorais. 
REFERÊNCIAS 


\section{Referências $^{1}$}

ANTONIA, S. J. et al. Phase I trial of a B7-1 (CD80) gene modified autologous tumor cell vaccine in combination with systemic interleukin-2 in patients with metastatic renal cell carcinoma. J. Urol., v. 167, p. 1995-2000, 2002.

BALEEIRO, R. B.; BARBUTO, J. A. Local secretion/shedding of tumor-derived CD83 molecules as a novel tumor escape mechanism. Mol. Immunol., v. 45, n. 12, p. 35023504, 2008.

BANCHEREAU, J. et al. Immunobiology of dendritic cells. Annu. Rev. Immunol., v. 18, p. 767-811, 2000.

BANCHEREAU, J.; PALUCKA, A. K. Dendritic cells as therapeutic vaccines against cancer. Nat. Rev. Immunol., v. 5, n. 4, p. 296-306, 2005.

BARBUTO, J. A. Are dysfunctional monocyte-derived dendritic cells in cancer an explanation for cancer vaccine failures? Immunotherapy, v. 5, n. 2, p. 105-107, 2013.

BARBUTO, J. A. et al. Dendritic cell-tumor cell hybrid vaccination for metastatic cancer. Cancer Immunol. Immunother., v. 53, n. 12, p. 1111-1118, 2004.

BAUGH, L. R. et al. Quantitative analysis of mRNA amplification by in vitro transcription. Nucleic Acids Res., v. 29, n. 5, p. e29, 2001.

BENZ, C. C. et al. Estrogen-dependent, tamoxifen-resistant tumorigenic growth of MCF-7 cells transfected with HER2/neu. Breast Cancer Res. Treat., v. 24, n. 2, p. 85-95, 1992.

\footnotetext{
${ }^{1}$ De acordo com: ASSOCIAÇÃO BRASILEIRA DE NORMAS TÉCNICAS. NBR 6023: Informação e documentação: referências: elaboração. Rio de Janeiro, 2002.
} 
BERGANT, M. et al. Preparation of native and amplified tumour RNA for dendritic cell transfection and generation of in vitro anti-tumour CTL responses. Immunobiology, v. 211, n. 3, p. 179-189, 2006.

BIRON, C. A. Interferons alpha and beta as immune regulators--a new look. Immunity, v. 14, n. 6, p. 661-664, 2001.

BOCZKOWSKI, D. et al. Induction of tumor immunity and cytotoxic T lymphocyte responses using dendritic cells transfected with messenger RNA amplified from tumor cells. Cancer Res., v. 60, n. 4, p. 1028-1034, 2000.

BROSSART, P. et al. Induction of cytotoxic T-lymphocyte responses in vivo after vaccinations with peptide-pulsed dendritic cells. Blood, v. 96, n. 9, p. 3102-3108, 2000.

CAO, M. D.; CHEN, Z. D.; XING, Y. Gamma irradiation of human dendritic cells influences proliferation and cytokine profile of T cells in autologous mixed lymphocyte reaction. Cell Biol. Int., v. 28, n. 3, p. 223-228, 2004.

CAO, W.; LEE, S. H.; LU, J. CD83 is preformed inside monocytes, macrophages and dendritic cells, but it is only stably expressed on activated dendritic cells. Biochem. J., v. 385, p. 85-93, 2005.

CARUSO, D. A. et al. Results of a phase 1 study utilizing monocyte-derived dendritic cells pulsed with tumor RNA in children and young adults with brain cancer. Neuro Oncol., v. 6, n. 3, p. 236-246, 2004.

CARUSO, D. A. et al. Results of a Phase I study utilizing monocyte-derived dendritic cells pulsed with tumor RNA in children with Stage 4 neuroblastoma. Cancer, v. 103, n. 6, p. 1280-1291, 2005.

CATHELIN, D. et al. Dendritic cell-tumor cell hybrids and immunotherapy: what's next? Cytotherapy, v. 13, n. 7, p. 774-785, 2011. 
CAUX, C. et al. GM-CSF and TNF-alpha cooperate in the generation of dendritic Langerhans cells. Nature, v. 360, n. 6401, p. 258-261, 1992.

CAUX, C. et al. Activation of human dendritic cells through CD40 cross-linking. J. Exp. Med., v. 180, n. 4, p. 1263-1272, 1994.

CHUNG, D. J. et al. Langerhans-type and monocyte-derived human dendritic cells have different susceptibilities to mRNA electroporation with distinct effects on maturation and activation: implications for immunogenicity in dendritic cell-based immunotherapy. J. Transl. Med., v. 11, p. 166, 2013.

DE GRUIJL, T. D. et al. Whole-cell cancer vaccination: from autologous to allogeneic tumor- and dendritic cell-based vaccines. Cancer Immunol. Immunother., v. 57, n. 10, p. 1569-1577, 2008.

DELLA BELLA, S.; CLERICI, M.; VILLA, M. L. Disarming dendritic cells: a tumor strategy to escape from immune control? Expert. Rev. Clin. Immunol., v. 3, n. 3, p. 411-422, 2007.

DUNN, G. P. et al. Cancer immunoediting: from immunosurveillance to tumor escape.

Nat. Immunol., v. 3, n. 11, p. 991-998, 2002.

ENG-WONG, J.; ISAACS, C. Prediction of benefit from adjuvant treatment in patients with breast cancer. Clin. Breast Cancer, v. 10, p. E32-E37, 2010.

FOX, B. A. et al. Lipofection indirectly increases expression of endogenous major histocompatibility complex class I molecules on tumor cells. Cancer Gene Ther., v. 5, n. 5, p. 307-312, 1998.

FRY, T. J. et al. Antigen loading of DCs with irradiated apoptotic tumor cells induces improved anti-tumor immunity compared to other approaches. Cancer Immunol. Immunother., v. 58, n. 8, p. 1257-1264, 2009. 
GABRILOVICH, D. Mechanisms and functional significance of tumour-induced dendriticcell defects. Nat. Rev. Immunol., v. 4, n. 12, p. 941-952, 2004.

GAO, L. et al. Impact of transfection with total RNA of K562 cells upon antigen presenting, maturation, and function of human dendritic cells from peripheral blood mononuclear cells. Transfusion, v. 47, n. 2, p. 256-265, 2007.

GILBOA, E.; VIEWEG, J. Cancer immunotherapy with mRNA-transfected dendritic cells. Immunol. Rev., v. 199, p. 251-263, 2004.

GONG, J. et al. Induction of antitumor activity by immunization with fusions of dendritic and carcinoma cells. Nat. Med., v. 3, n. 5, p. 558-561, 1997.

GRIMM, E. A. et al. Lymphokine-activated killer cell phenomenon. III. Evidence that IL-2 is sufficient for direct activation of peripheral blood lymphocytes into lymphokine-activated killer cells. J. Exp. Med., v. 158, n. 5, p. 1356-1361, 1983.

GRÜNEBACH, F. et al. Delivery of tumor-derived RNA for the induction of cytotoxic Tlymphocytes. Gene Ther., v. 10, n. 5, p. 367-374, 2003.

HALLER HASSKAMP, J.; ZAPAS, J. L.; ELIAS, E. G. Dendritic cell counts in the peripheral blood of healthy adults. Am. J. Hematol., v. 78, n. 4, p. 314-315, 2005.

HEISER, A. et al. Induction of polyclonal prostate cancer-specific CTL using dendritic cells transfected with amplified tumor RNA. J. Immunol., v. 166, n. 5, p. 2953-2960, 2001.

HERRMANN, F. et al. HER-2/neu-mediated regulation of components of the MHC class I antigen-processing pathway. Cancer Res., v. 64, n. 1, p. 215-220, 2004. 
HUANG, $\mathrm{H}$. et al. Effects of two different antigen-loading methods on the activity of dendritic cell vaccine for colorectal carcinoma cell inhibition in vitro. Nan Fang Yi Ke Da Xue Xue Bao, v. 27, n. 4, p. 492-495, 2007.

HUANG, Q. et al. The plasticity of dendritic cell responses to pathogens and their components. Science, v. 294, n. 5543, p. 870-875, 2001.

INABA, K.; YOUNG, J. W.; STEINMAN, R. M. Direct activation of CD8+ cytotoxic T lymphocytes by dendritic cells. J. Exp. Med., v. 166, n. 1, p. 182-194, 1987.

ITO, T.; LIU, Y. J.; KADOWAKI, N. Functional diversity and plasticity of human dendritic cell subsets. Int. J. Hematol., v. 81, n. 3, p. 188-196, 2005.

KANEKO, K. et al. Clinical implication of HLA class I expression in breast cancer. BMC Cancer, v. 11, p. 454-454, 2011.

KAPSENBERG, M. L. Dendritic-cell control of pathogen-driven T-cell polarization. Nat. Rev. Immunol., v. 3, n. 12, p. 984-993, 2003.

KOIDO, S. et al. Immunologic monitoring of cellular responses by dendritic/tumor cell fusion vaccines. J. Biomed. Biotechnol., v. 2011, p. 910836, 2011.

KOIDO, S.; GONG, J. Characterization of structure and direct antigen presentation by dendritic/tumor-fused cells as cancer vaccines. Anticancer Res., v. 33, n. 2, p. 347-354, 2013.

LIVAK, K. J.; SCHMITTGEN, T. D. Analysis of relative gene expression data using realtime quantitative PCR and the 2(-Delta Delta C(T)) Method. Methods, v. 25, n. 4, p. $402-$ 408, 2001. 
LÓPEZ, M. N. et al. Prolonged survival of dendritic cell-vaccinated melanoma patients correlates with tumor-specific delayed type IV hypersensitivity response and reduction of tumor growth factor beta-expressing T cells. J. Clin. Oncol., v. 27, n. 6, p. 945-952, 2009.

LU, D. et al. Optimization of methods to achieve mRNA-mediated transfection of tumor cells in vitro and in vivo employing cationic liposome vectors. Cancer Gene Ther., v. 1, n. 4, p. 245-252, 1994.

MALDONADO, R. A.; VON ANDRIAN, U. H. How tolerogenic dendritic cells induce regulatory T cells. Adv. Immunol., v. 108, p. 111-165, 2010.

MCARTHUR, H. L.; HUDIS, C. A. Adjuvant chemotherapy for early-stage breast cancer. Hematol. Oncol. Clin. North. Am., v. 21, n. 2, p. 207-222, 2007.

MELLMAN, I.; STEINMAN, R. M. Dendritic cells: specialized and regulated antigen processing machines. Cell, v. 106, n. 3, p. 255-258, 2001.

MERKENS, L. S.; BRYAN, S. K.; MOSES, R. E. Inactivation of the 5'-3' exonuclease of Thermus aquaticus DNA polymerase. Biochim. Biophys. Acta., v. 1264, n. 2, p. 243248, 1995.

MILANO, F. et al. An ex vivo readout for evaluation of dendritic cell-induced autologous cytotoxic T lymphocyte responses against esophageal cancer. Cancer Immunol. Immunother., v. 56, n. 12, p. 1967-1977, 2007.

MILAZZO, C. et al. Induction of myeloma-specific cytotoxic T cells using dendritic cells transfected with tumor-derived RNA. Blood, v. 101, n. 3, p. 977-982, 2003.

MOSCA, P. J. et al. Dendritic cell vaccines. Front. Biosci., v. 12, p. 4050-4060, 2007. 
MÜLLER, M. R. et al. Induction of chronic lymphocytic leukemia (CLL)-specific CD4- and CD8-mediated T-cell responses using RNA-transfected dendritic cells. Blood, v. 103, n. 5, p. 1763-1769, 2004.

NATIONAL CANCER INSTITUTE. SEER incidence and NCHS mortality statistics. SEER Cancer Statistics Review 1975-2010, 2012. Disponivel em: <http://seer.cancer.gov/csr/1975_2010/>. Acesso em: 18 Outubro 2013.

NENCIONI, A. et al. Dendritic cells transfected with tumor RNA for the induction of antitumor CTL in colorectal cancer. Cancer Gene Ther., v. 10, n. 3, p. 209-214, 2003.

NEVES, A. R. et al. Dendritic cells derived from metastatic cancer patients vaccinated with allogeneic dendritic cell-autologous tumor cell hybrids express more CD86 and induce higher levels of interferon-gamma in mixed lymphocyte reactions. Cancer Immunol. Immunother., v. 54, n. 1, p. 61-66, 2005.

$\mathrm{NI}$, X. et al. Induction of T-cell responses against cutaneous T-cell lymphomas ex vivo by autologous dendritic cells transfected with amplified tumor mRNA. J. Invest. Dermatol., v. 128, n. 11, p. 2631-2639, 2008.

PARISE, C. A. et al. Breast cancer subtypes as defined by the estrogen receptor (ER), progesterone receptor (PR), and the human epidermal growth factor receptor 2 (HER2) among women with invasive breast cancer in California, 1999-2004. Breast J., v. 15, n. 6, p. 593-602, 2009.

PINZON-CHARRY, A.; LÓPEZ, J. A. Tumor-Derived Factors Responsible for Dendritic Cell Dysfunction. In: SHURIN, M. R.; SALTER, R. D. Dendritic Cells in Cancer. New York: Springer, 2009. cap. 7, p. 103-117.

RAMOS, C.; TEISSIÉ, J. Electrofusion: a biophysical modification of cell membrane and a mechanism in exocytosis. Biochimie., v. 82, n. 5, p. 511-518, 2000. 
RAMOS, R. N. et al. Monocyte-derived dendritic cells from breast cancer patients are biased to induce CD4+CD25+FoxP3+ regulatory T cells. J. Leukocyte Biol., v. 92, n. 3, p. 673-682, 2012.

REUBEN, J. M. et al. The effect of low dose gamma irradiation on the differentiation and maturation of monocyte derived dendritic cells. J. Gravit. Physiol., v. 11, n. 2, p. 49-52, 2004.

ROMAGNOLI, G. G. et al. Tumour cells incorporate exosomes derived from Dendritic Cells through a mechanism involving the tetraspanin CD9. Exosomes and Microvesicles, v. 4, p. 21-32, 2013.

SALLUSTO, F. et al. Distinct patterns and kinetics of chemokine production regulate dendritic cell function. Eur. J. Immunol., v. 29, n. 5, p. 1617-1625, 1999.

SALLUSTO, F.; LANZAVECCHIA, A. Efficient presentation of soluble antigen by cultured human dendritic cells is maintained by granulocyte/macrophage colony-stimulating factor plus interleukin 4 and downregulated by tumor necrosis factor alpha. J. Exp. Med., v. 179, n. 4, p. 1109-1118, 1994.

SANTOS, A. P. S. A. Efeito do microambiente tumoral sobre as características funcionais e fenotípicas de células dendríticas geradas in vitro a partir de monócitos do sangue periférico de voluntárias saudáveis e de pacientes com câncer de mama. 115 p. Tese (Doutorado em Imunologia) - Instituto de Ciências Biomédicas, Universidade de São Paulo, 2010.

SCANDELLA, E. et al. Prostaglandin E2 is a key factor for CCR7 surface expression and migration of monocyte-derived dendritic cells. Blood, v. 100, n. 4, p. 1354-1361, 2002.

SELIGER, B. Molecular mechanisms of MHC class I abnormalities and APM components in human tumors. Cancer Immunol. Immunother., v. 57, n. 11, p. 1719-1726, 2008. 
SHAGIN, D. A. et al. Regulation of average length of complex PCR product. Nucleic Acids Res., v. 27, n. 18, p. e23-e23, 1999.

SHAPIRO, C. L.; RECHT, A. Side effects of adjuvant treatment of breast cancer. N. Engl. J. Med., v. 344, n. 26, p. 1997-2008, 2001.

SIMMS, P. E.; ELLIS, T. M. Utility of flow cytometric detection of CD69 expression as a rapid method for determining poly- and oligoclonal lymphocyte activation. Clin. Diagn. Lab. Immunol., v. 3, n. 3, p. 301-304, 1996.

SOMMER, S. S.; COHEN, J. E. The size distributions of proteins, mRNA, and nuclear RNA. J. Mol. Evol., v. 15, n. 1, p. 37-57, 1980.

SRIVATSAN, S. et al. Allogeneic tumor cell vaccines: The promise and limitations in clinical trials. Hum .Vaccin. Immunother., v. 10, n. 1, 2013.

STEINMAN, R. M. Some interfaces of dendritic cell biology. APMIS, v. 111, n. 7-8, p. 675-697, 2003.

STEINMAN, R. M. The control of immunity and tolerance by dendritic cell. Pathol. Biol., v. 51, n. 2, p. 59-60, 2003.

STEINMAN, R. M.; BANCHEREAU, J. Taking dendritic cells into medicine. Nature, v. 449, n. 7161, p. 419-426, 2007.

SU, Z. et al. Immunological and clinical responses in metastatic renal cancer patients vaccinated with tumor RNA-transfected dendritic cells. Cancer Res., v. 63, n. 9, p. 21272133, 2003.

SUNDARASETTY, B. S. et al. Lentivirus-induced dendritic cells for immunization against high-risk WT1(+) acute myeloid leukemia. Hum. Gene. Ther., v. 24, n. 2, p. 220-237, 2013. 
SUZUKI, K. et al. Transfection of single-stranded hepatitis A virus RNA activates MHC class I pathway. Clin. Exp. Immunol., v. 127, n. 2, p. 234-242, 2002.

TAN, J. T. et al. IL-7 is critical for homeostatic proliferation and survival of naïve T cells. Proc Natl. Acad. Sci. U. S. A., v. 98, n. 15, p. 8732-8737, 2001.

THIBODEAU, J.; BOURGEOIS-DAIGNEAULT, M. C.; LAPOINTE, R. Targeting the MHC Class II antigen presentation pathway in cancer immunotherapy. Oncoimmunology., v. 1, n. 6, p. 908-916, 2012.

TONIOLO, P. A. Avaliação da transfecção de células dendríticas com RNA tumoral como estratégia para indução de imunidade específica em pacientes com leucemia linfóide crônica. 129 p. Tese (Mestrado em Imunologia) - Instituto de Ciências Biomédicas, Universidade de São Paulo, 2010.

TRAUTMANN, L. et al. Selection of T cell clones expressing high-affinity public TCRs within Human cytomegalovirus-specific CD8 T cell responses. J. Immunol., v. 175, n. 9, p. 6123-6132, 2005.

TREFZER, U. et al. Tumour-dendritic hybrid cell vaccination for the treatment of patients with malignant melanoma: immunological effects and clinical results. Vaccine, v. 23, n. 17-18, p. 2367-2373, 2005.

TREFZER, U.; WALDEN, P. Hybrid-cell vaccines for cancer immune therapy. Mol. Biotechnol., v. 25, n. 1, p. 63-69, 2003.

VAN GELDER, R. N. et al. Amplified RNA synthesized from limited quantities of heterogeneous cDNA. Proc. Natl. Acad. Sci. U. S. A., v. 87, n. 5, p. 1663-1667, 1990.

YANG, J. Y. et al. Dendritic cells fused with allogeneic hepatocellular carcinoma cell line compared with fused autologous tumor cells as hepatocellular carcinoma vaccines.

Hepatol. Res., v. 40, n. 5, p. 505-513, 2010. 